\title{
Thick-skinned tectonics and basement-involved fold-thrust belts: insights from selected Cenozoic orogens
}

\author{
OLIVIER LACOMBE* \& NICOLAS BELLAHSEN \\ Sorbonne Universités, UPMC Univ Paris 06, CNRS, Institut des Sciences de la Terre de Paris (iSTeP), \\ 4 place Jussieu 75005 Paris, France
}

(Received 31 October 2015; accepted 18 January 2016; first published online 20 April 2016)

\begin{abstract}
Defining the structural style of fold-thrust belts and understanding the controlling factors are necessary steps towards prediction of their long-term and short-term dynamics, including seismic hazard, and to assess their potential in terms of hydrocarbon exploration. While the thin-skinned structural style has long been a fashionable view for outer parts of orogens worldwide, a wealth of new geological and geophysical studies has pointed out that a description in terms of thick-skinned deformation is, in many cases, more appropriate. This paper aims at providing a review of what we know about basement-involved shortening in foreland fold-thrust belts on the basis of the examination of selected Cenozoic orogens. After describing how structural interpretations of fold-thrust belts have evolved through time, this paper addresses how and the extent to which basement tectonics influence their geometry and their kinematics, and emphasizes the key control exerted by lithosphere rheology, including structural and thermal inheritance, and local/regional boundary conditions on the occurrence of thick-skinned tectonics in the outer parts of orogens.
\end{abstract}

Keywords: thick-skinned tectonics, basement-involved shortening, inversion tectonics, thermostructural inheritance, crust mechanics, lithosphere rheology.

\section{Introduction}

The depth (and degree) of décollement within the continental crust during (collisional) deformation has been widely debated for many years (e.g. Pfiffner, 2006). Two extreme opposing views have arisen through time for the interpretation of foreland fold-thrust belts (FTBs). One view states that the sedimentary cover is detached from the underlying basement along a shallow, low-strength décollement and deformed by thrusts with ramp-flat geometries rooting into the décollement (thin-skinned tectonic style). This thin-skinned style supposes large-scale displacements and duplication of the sedimentary sequence, the underlying basement remaining undeformed. The alternative view states that the basement is also involved in the deformation along crustal-scale ramps (thick-skinned tectonic style). A major difference between the two end-member models is that the amount of shortening is more conservative in a thick-skinned context, especially if inversion tectonics is involved (e.g. Butler et al. 2004).

The term thick-skinned is used hereinafter in a slightly different and somewhat broader sense than sometimes found in the literature. Compared to Rodgers (1949), for whom thin-skinned implies cover deformation only (part of the cover being decoupled from the basement), whereas thick-skinned implies deformation of both cover and basement (the cover remaining welded to the basement), we consider that the two styles of deformation are not mutually exclusive,

*Author for correspondence: olivier.lacombe@upmc.fr i.e. both superimposed structural styles may occur coevally. We further do not distinguish between FTBs with a thin-skinned structural style and basementinvolved belts with a thick-skinned structural style as done by Poblet \& Lisle (2011), and we chose hereinafter to simply speak about thick-skinned FTBs. Finally, we do not restrict the use of the term thick-skinned to the cases where the entire crust is involved as suggested by Pfiffner (2006), and we also use it to describe thrust sheets made of upper crustal flakes only.

There are different ways to define the basement (e.g. Allaby \& Allaby, 1991; Holbrook, Mooney \& Christensen, 1992; Sheriff, 2002). Structural geologists often define the basement as any rock, generally of crystalline nature, that underlies a specific stratigraphic cover sequence; in this case, the term 'basement' is used to describe the upper part of the crystalline crust. Geophysicists define the basement on the basis of reflectivity pattern or physical properties (e.g. seismic wave velocities, magnetic or gravimetric signature) to be compared to those of the overlying sedimentary rocks. When addressing the rheology of the material deformed in basement-involved, thick-skinned shortening one should theoretically distinguish the true crystalline basement from the overlying sedimentary cover sequence that remains welded to it. In practice, however, the contribution of the welded cover sequence - even bedded, hence expectedly anisotropic - to the bulk mechanical behaviour of the deformed material is quantitatively negligible, the latter being mainly controlled by the crystalline upper crustal rocks. In the following, the term 'basement' will refer to the true 

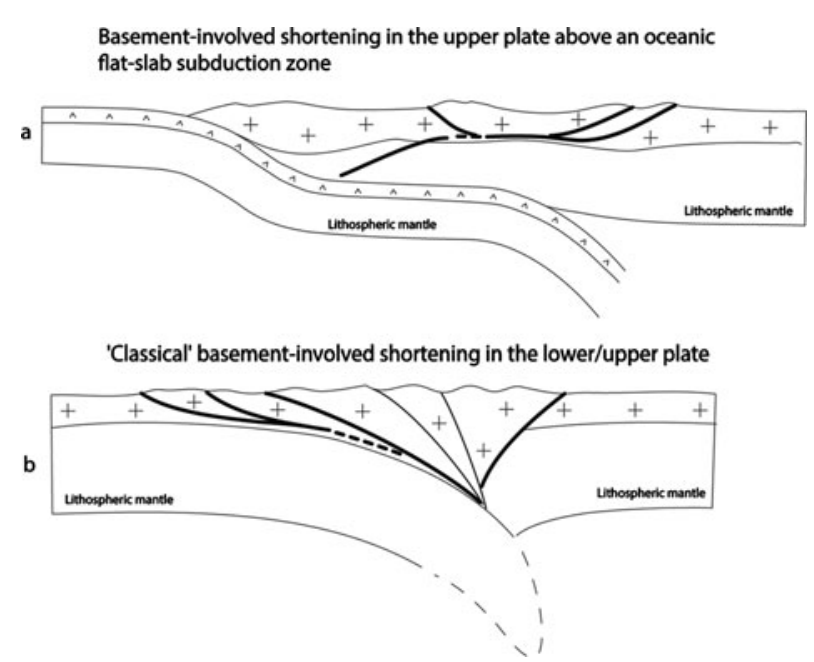

Figure 1. Main geodynamic and tectonic settings of basementinvolved FTBs.

crystalline upper crust, but for the sake of clarity and exactness, possible deviation from this definition will be discussed specifically if needed (e.g. Taiwan).

Many FTBs exhibit both thin- and thick-skinned structural styles in different portions of the belt. Some, like the Andes, change style along-strike (e.g. Watts et al. 1995; Allmendinger et al. 1997; Baby et al. 2013; Carrera \& Munoz, 2013; Iaffa et al. 2013). Others, like the Rocky Mountains, exhibit a thin-skinned structural style in their interior (Sevier belt) and thick-skinned style (Laramide belt) in their exterior (e.g. Hamilton, 1988). Nemcok, Schamel \& Gayer (2005) and Nemcok, Mora \& Cosgrove (2013) emphasized that $50 \%$ of orogens for which deformation styles are known show a thick-skinned character and have evolved from either passive margins or intra-cratonic rifts.

Thick-skinned FTBs mainly form at the expense of lower and/or upper plates during collision in "Alpinetype' orogens, in pro-wedge and retro-wedge settings (e.g. Alps, Apennines, Carpathians, Balkans) (Fig. 1a) or within the upper plate of subduction orogens (retrowedge setting: Rocky Mountains, Sierras Pampeanas of the Argentine Andes) (Fig. 1b). Thick-skinned FTBs are also encountered - even more rarely - in intraplate settings (e.g. North Sea region, High Atlas of Morocco; Teixell et al. 2003).

In areas where shortening was preceded by rifting, deep-rooting, inversion-dominated deformation likely prevailed during the building of FTBs. Reactivation/inversion of basement faults widely occurs during orogenic evolution of collided passive margins and inverted intracontinental rifts and this process is known to exert a strong control on the evolution of orogens (e.g. Jackson, 1980; Winslow, 1981; Gillcrist, Coward \& Mugnier, 1987; Roure et al. 1990; Letouzey, 1990; Dechesne \& Mountjoy, 1992; Coward, 1994; Berberian, 1995; Mitra \& Mount, 1998; Coward et al. 1999; Sandiford, 1999; Brown et al. 1999; Cristallini \& Ramos, 2000; Kley \& Monaldi, 2002; Lacombe \& Mouthereau, 2002; Mouthereau et al. 2002; Mouthereau \&
Lacombe, 2006; Butler, Tavarnelli \& Grasso, 2006; Carrera et al. 2006; Scisciani, 2009; Bonini, Sani \& Antonielli, 2012; Alvarez-Marron et al. 2014; Camanni et al. 2014).

Fault inversion is a complex and selective process that depends on the orientation and steepness of the fault plane, the friction along the fault plane and the contrast of this frictional strength with respect to that of the surrounding medium (Letouzey, 1990; Sassi et al. 1993; Sibson, 1995; Roure \& Colletta, 1996; Butler, Holdsworth \& Lloyd, 1997; Holdsworth, Buick \& Hand, 2001; Turner \& Williams, 2004; Butler, Tavarnelli \& Grasso, 2006; Roure, 2008; Scisciani, 2009; Bonini, Sani \& Antonielli, 2012; Bellahsen et al. 2012). Even when they are not reactivated, pre-existing faults are important mechanical discontinuities that can generate stress concentration and buttressing effects and often localize thrust ramps (Tricart \& Lemoine, 1986; Gillcrist, Coward \& Mugnier, 1987; Coward, Gillcrist \& Trudgill, 1991; Butler, Tavarnelli \& Grasso, 2006; Mattioni, Sassi \& Callot, 2007; Scisciani, 2009; Cooper \& Warren, 2010; Bonini, Sani \& Antonielli, 2012; Bellahsen et al. 2014; Boutoux et al. 2014). Reactivated basement faults may induce localization of thrusts and folds in the developing shallow thrust wedge, development of basement uplifts or crystalline thrust sheets, out-of-sequence thrusting and refolding of shallow nappes or development of accommodation structures such as lateral ramps, among others.

In no longer active Cenozoic FTBs (e.g. PyreneesProvence, Rocky Mountains), thick-skinned tectonics can be documented by geophysical investigations (gravimetry, seismics) for buried structures and by structural investigations of basement uplifts and exposed basement-cored structures where the relationships between cover and basement can be deciphered, together with exhumed basement shear zones (e.g. Smithson et al. 1979; Roure et al. 1989; Stone, 1993; Schmidt, Genovese \& Chase, 1993; Roure \& Colletta, 1996; Fan \& Carrapa, 2014) (Fig. 2). In more recent and still active orogens (e.g. western Alps, Sierras Pampeanas, Zagros, Taiwan), the integrated approach combining geophysical (geodesy, gravimetry, seismics) and structural investigations can be complemented by seismological and thermochronological studies to document basement thrusting and uplift and to unravel structural style and occurrence of deep inversion tectonics (e.g. Mosar, 1999; Lacombe \& Mouthereau, 2002; Camanni et al. 2014; Siame et al. 2015) (Fig. 2).

A brief review of some Cenozoic FTBs demonstrates that basement shortening may have various types of occurrence, later discussed in the sections of this paper. They include Oisans (western Alps) style, with distributed shearing within the basement reflecting basement underplating then frontal accretion/exhumation thanks to crustal thrust ramps (Fig. 3a; Bellahsen et al. 2012); Mont Blanc (western Alps) style, with stacking of crustal slices at the rear of the thin-skinned FTB as a result of basement underplating and localized exhumation then frontal accretion/exhumation thanks to 


\section{Tertiary fold-thrust belts}

\section{e.g. Western Alps}

\section{e.g. Pyrenees,}

\section{Western Alps}

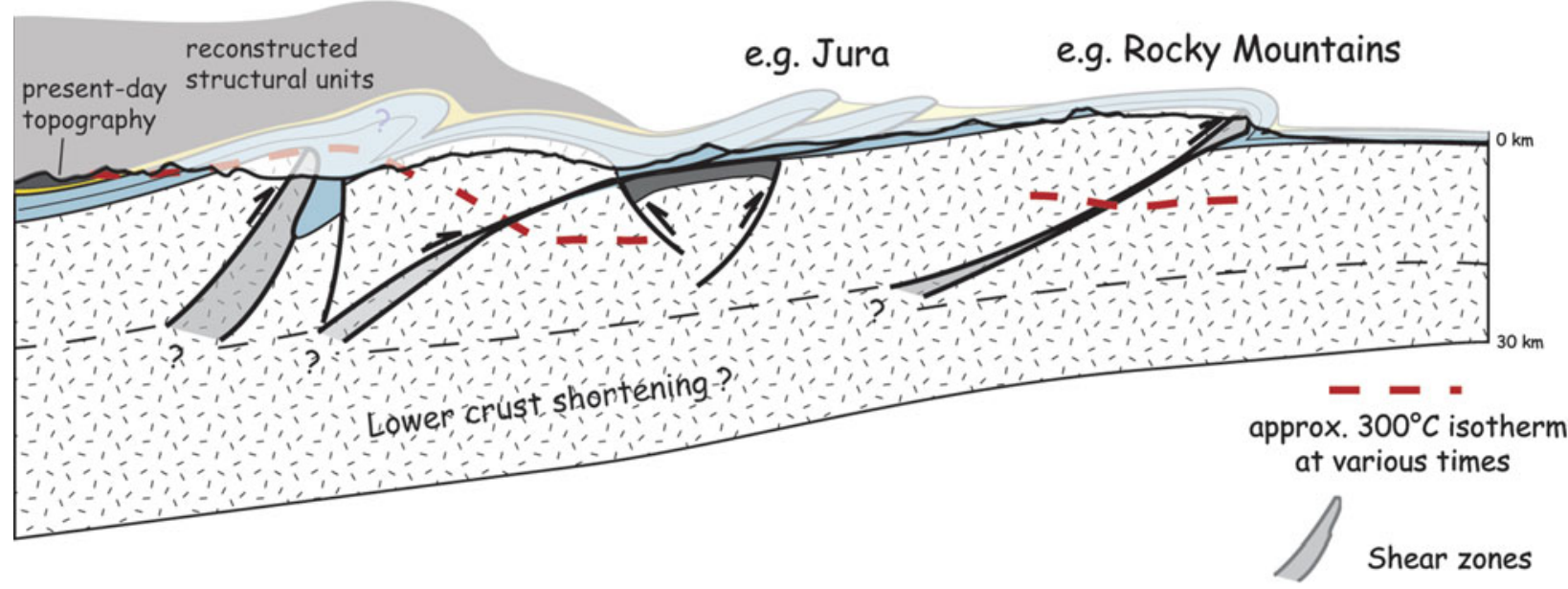

\section{Active fold-thrust belts}

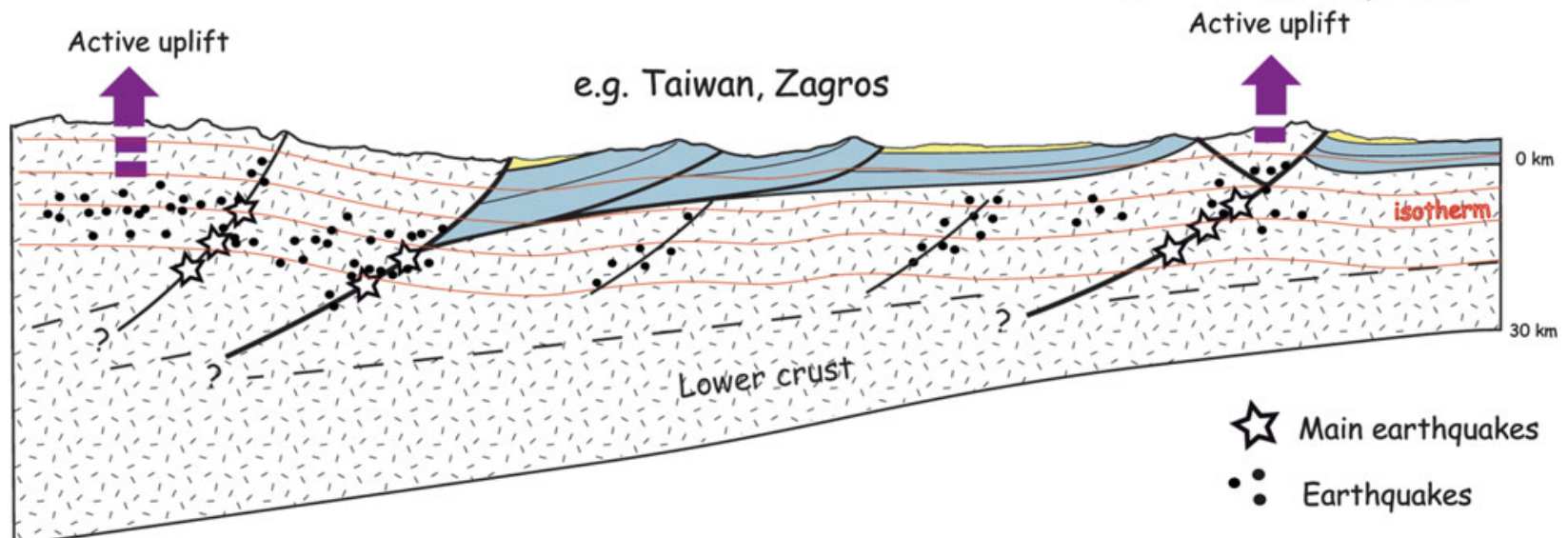

Figure 2. (Colour online) Main characteristics of Tertiary and recent/active FTBs possibly documenting basement-involved, thickskinned tectonics.

crustal thrust ramps (Fig. 3b; Burkhard \& Sommaruga, 1998); Zagros style, with superimposed thin-skinned and thick-skinned tectonic styles (Fig. 3c; Mouthereau et al. 2007) or Sierras Pampeanas-Laramide style with the basement being involved within the foreland of the thin-skinned FTB (e.g. Laramide uplifts in the foreland of the Sevier belt and Sierras Pampeanas uplifts in the foreland of the Precordillera belt; Fig. 3d) (e.g. Hamilton, 1988).

It thus comes that after two decades of fashionable interpretation of FTBs in terms of thin-skinned tectonics, there are increasing lines of evidence of basementinvolved shortening in FTBs, even in the 'archetypal' thin-skinned belts. Recently, Mouthereau, Watts \& Burov (2013) proposed that FTBs can be gathered into two groups characterized by contrasting amounts of shortening and thermotectonic age of the lithosphere from which they developed. An important implication of this work could be that boundary conditions (plate kinematics, interplate coupling, synorogenic sedimentation, among others) may have little or no effect on the deformation style, being only controlled by the rheology of the lithosphere as inherited from the last thermotectonic (rifting) event before shortening. This view, however, does not take into account for instance those inner parts of the FTBs that possibly underwent synconvergence, early collisional burial and heating before being shortened (e.g. Bellahsen et al. 2014).

This motivated this review of selected Cenozoic orogens worldwide, in an attempt at examining the evolution of ideas about FTBs and the extent to which the basement controls the geometry, kinematics and mechanics of foreland FTBs, and at addressing and evaluating in particular the role of crustal (lithospheric) strength, thickness and anisotropy, plate-tectonic setting, deposition leading to burial, depth to décollement 

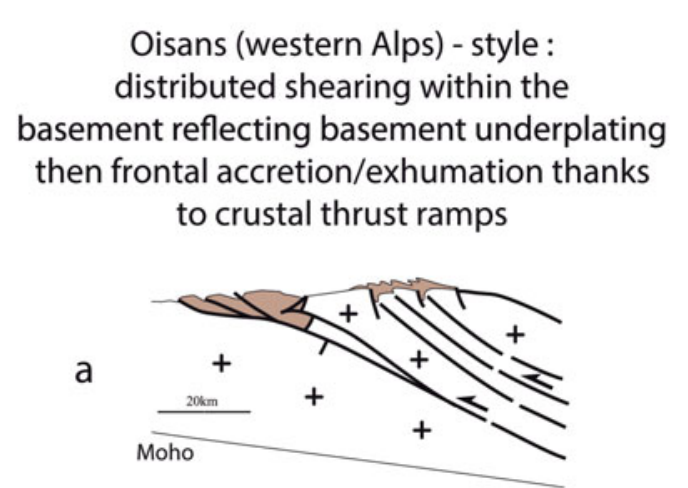

\author{
Mont Blanc (western Alps) - style : \\ Stacking of crustal slices at the rear of the thin-skinned \\ fold-thrust belt as a result of basement \\ underplating and localized exhumation then \\ frontal accretion/exhumation thanks \\ to crustal thrust ramps
}

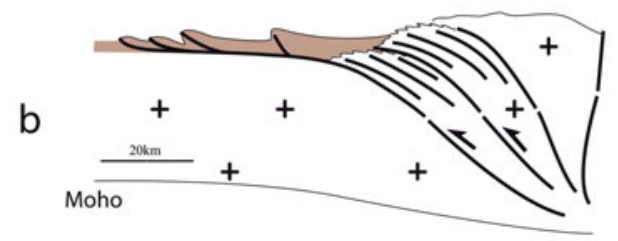

Zagros -style : superimposed thin-skinned and thick-skinned tectonic styles.

The basement deforms by both seismogenic faulting and ductile aseismic shearing below the deforming detached cover

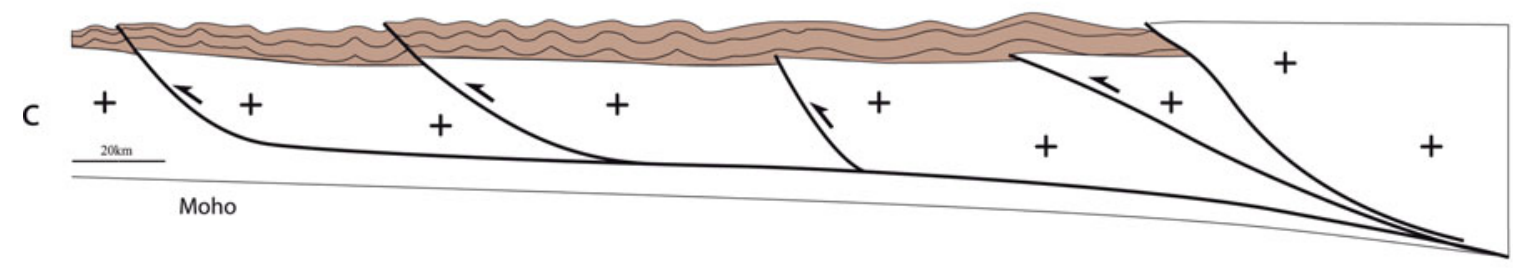

Sierras Pampeanas-Laramide - style : the basement is involved in the foreland of the thin-skinned belt (basement uplifts).

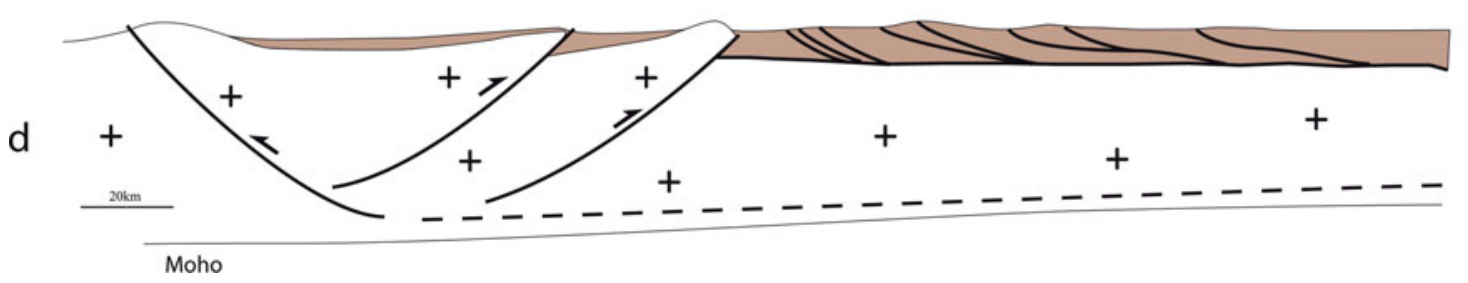

Figure 3. (Colour online) Examples of Cenozoic FTBs with different styles of basement-involved shortening. (a) Oisans (western Alps) style, with distributed shearing within the basement reflecting basement underplating then frontal accretion/exhumation thanks to crustal thrust ramps; (b) Mont Blanc (western Alps) style, with stacking of crustal slices at the rear of the frontal thin-skinned FTB as a result of basement underplating and localized exhumation then frontal accretion/exhumation thanks to crustal thrust ramps; (c) Zagros style, with superimposed thin-skinned and thick-skinned tectonic styles; (d) Sierras Pampeanas-Laramide style with the basement being involved in shortening in the foreland (Laramide/Sierras Pampeanas basement uplifts) of the thin-skinned FTBs (Sevier/Precordillera, respectively).

and occurrence of pre-existing basement structures on basement-involved shortening, hence on the structural style in the outer parts of mountain belts.

\section{Evolution of ideas and views about basement-involved deformation in FTBs: some examples}

The overall geometry and mechanics of foreland FTBs are well accounted for by the Coulomb critical wedge model (Chapple, 1978; Davis, Suppe \& Dahlen, 1983; Dahlen, Suppe \& Davis, 1984; Stockmal et al. 2007). This model describes FTBs as critically tapered wedges made of homogeneous deformable material moving above an undeformed substratum along a shallow, lowdipping décollement. Since Davis, Suppe \& Dahlen's (1983) seminal paper, critically tapered wedge mech- anics has greatly influenced our view on the mountainbuilding processes, even though the model fundamentally meets the important restrictions that the deformable material of natural wedges is not homogeneous and that the substratum below the basal décollement horizon is not rigid and undeformable as assumed or implied by the theory.

The Coulomb theory has been stated in Davis, Suppe \& Dahlen's (1983) paper as to expectedly break down where the wedge thickens to the depth below which the basal resistance to sliding drops abruptly with increasing temperature ('brittle-ductile' transition). Although there is no theoretical limitation in applying the critically tapered wedge model to thick (-skinned) orogenic wedges - the bases of which extend down to and below the depth of the frictional to viscous transition provided the theory is modified to take into account the 
temperature-dependent viscosity of crustal material at depth (e.g. Williams et al. 1994; Mouthereau, Lacombe \& Meyer, 2006), this point has likely unconsciously hampered thinking equally in terms of thick-skinned tectonics and thin-skinned tectonics; the deformable material of the wedge has therefore often been considered to be restricted to the detached cover, which led to favouring thin-skinned tectonics.

As a result, in the 1980-90s structural sections across many outer parts of orogens were built, either explicitly or implicitly, assuming thin-skinned tectonic mechanisms. Because deformation of a sedimentary layer requires a lower amount of deviatoric yielding stress than deformation of the underlying crystalline basement rocks, thin-skinned tectonic style is usually expected at the thrust front of orogens, especially in the absence of well-oriented, pre-existing crustal weaknesses. As a consequence, in the absence of sound sub-surface evidence for basement involvement, thin-skinned deformation has generally been favoured with respect to the alternative thick-skinned mode, leading to often underestimating basement-involved shortening in the outer parts of orogens.

While in many cases surface geological structures are compatible with a model of shallow thrusting over a regional décollement in the sedimentary cover, a number of geological and geophysical data suggest that deeper levels of the crust are involved in the mountainbuilding process. In the following, we show on the basis of three famous FTBs the way our views and our understanding of the structural style have evolved.

\section{2.a. Taiwan}

The Taiwan orogen results from the active oblique collision of the young Chinese continental margin belonging to the Eurasian plate with the Luzon Arc that belongs to the oceanic Philippine Sea plate. The arc-continent collision started during late Miocene early Pliocene times as dated by the beginning of the flexural subsidence in early Pliocene time (Chang \& Chi, 1983). This collisional evolution post-dated the Eocene-Oligocene continental rifting and subsequent spreading associated with the opening of the South China Sea, as well as later Miocene extensional events that affected the Chinese margin.

The Taiwan orogen is divided into several tectonostratigraphic belts. To the east, the Coastal Range, mainly composed of Neogene volcanic rocks interbedded with intra-arc Pliocene basin deposits, is the northern extension of the Luzon Arc. The rocks exposed in the Central Range belong to a metamorphic belt (Mesozoic Tananao Complex) or a slate belt (Eocene to middle Miocene rocks). The Central Range results from the exhumation and emplacement of a complex assemblage of ancient sedimentary basins, volcanic deposits and oceanic materials (Teng, 1990). The Hsuehshan Range results from the inversion of the former extensional Hsuehshan Basin of the Chinese passive margin; it is made up of variably metamorphosed Eo- cene clastic sediments overlain by Oligocene shales and sandstones. The Western Foothills consist of a foreland FTB involving E-dipping imbricate thrust sheets. The thrust sheets are mainly composed of pre-tectonic Miocene shelf deposits of the Chinese platform. In addition, Pliocene-Pleistocene synorogenic sediments derived from the erosion of inner domains were deposited and incorporated into the propagating thrust units. To the west, the Coastal Plain consists of alluvial deposits poorly deformed at the surface (Figs 4, 8).

Since Suppe's pioneering works in Taiwan (Suppe, 1976, 1980; Suppe \& Namson, 1979; see also Namson, 1984), and the first test and illustration of the critically tapered wedge mechanics with data from Taiwan (Davis, Suppe \& Dahlen, 1983; Dahlen, Suppe \& Davis, 1984), ideas about the interpretation of surface structures at depth have considerably evolved, thanks to both newly acquired sub-surface data and challenging of the thin-skinned conceptual model by alternative views. Suppe \& Namson (1979) built the first balanced section across the Hsiaomei anticline interpreted as a fault-bend fold (Fig. 4a). According to these authors, the growth of this anticline was due to sliding above the Miocene Talu shales: this horizon is connected through a ramp to an upper décollement lying in the Pliocene Chinshui shales. In this interpretation, the decoupling/décollement level lies at 3-4 km depth in agreement with a thin-skinned deformation, while the pre-Miocene rocks of the Chinese continental margin are not involved in shortening (Fig. 4a). A more recent seismic profile allowed Hung et al. (1999) to propose that the formation of the Hsiaomei anticline may well be related to the reverse reactivation of the upper part of an inherited normal fault (Fig. 4b), which requires that the basal décollement, if present, is much deeper that that predicted for the fault-bend folding model (at $\sim 12 \mathrm{~km}$ depth within the pre-Miocene formations). In this view, however, the crystalline upper crust still remains undeformed. Finally, Yang et al. (2001) suggested that thrusting involving the pre-Miocene rocks may be responsible for the Hsiaomei anticline structure. This interpretation implicitly requires that thrusting is accommodated at a deep crustal level (Mouthereau \& Lacombe, 2006; Fig. 4c). Noticeably, shortening deduced from the thin-skinned interpretation is $10 \mathrm{~km}$, whereas the thick-skinned interpretation gives shortening of only $\sim 3 \mathrm{~km}$.

Another example is provided by the Chingtsaohu anticline in NW Taiwan, first interpreted by Namson (1981) as a fault-bend fold due to sliding below the Oligocene Wuchihshan Formation (Fig. 4d) in a thinskinned style of deformation. Yang et al. (1996) later reinterpreted the formation of this anticline as related to shallow thrusting rooting within shallow décollement levels such as the lower-middle Miocene Peiliao and Hopai-Tungkeng formations or the lower Pliocene Kueichulin Formation, and interacting with high-angle thrusting resulting from the reverse reactivation of an inherited normal fault of the Chinese passive margin (Fig. 4e). 


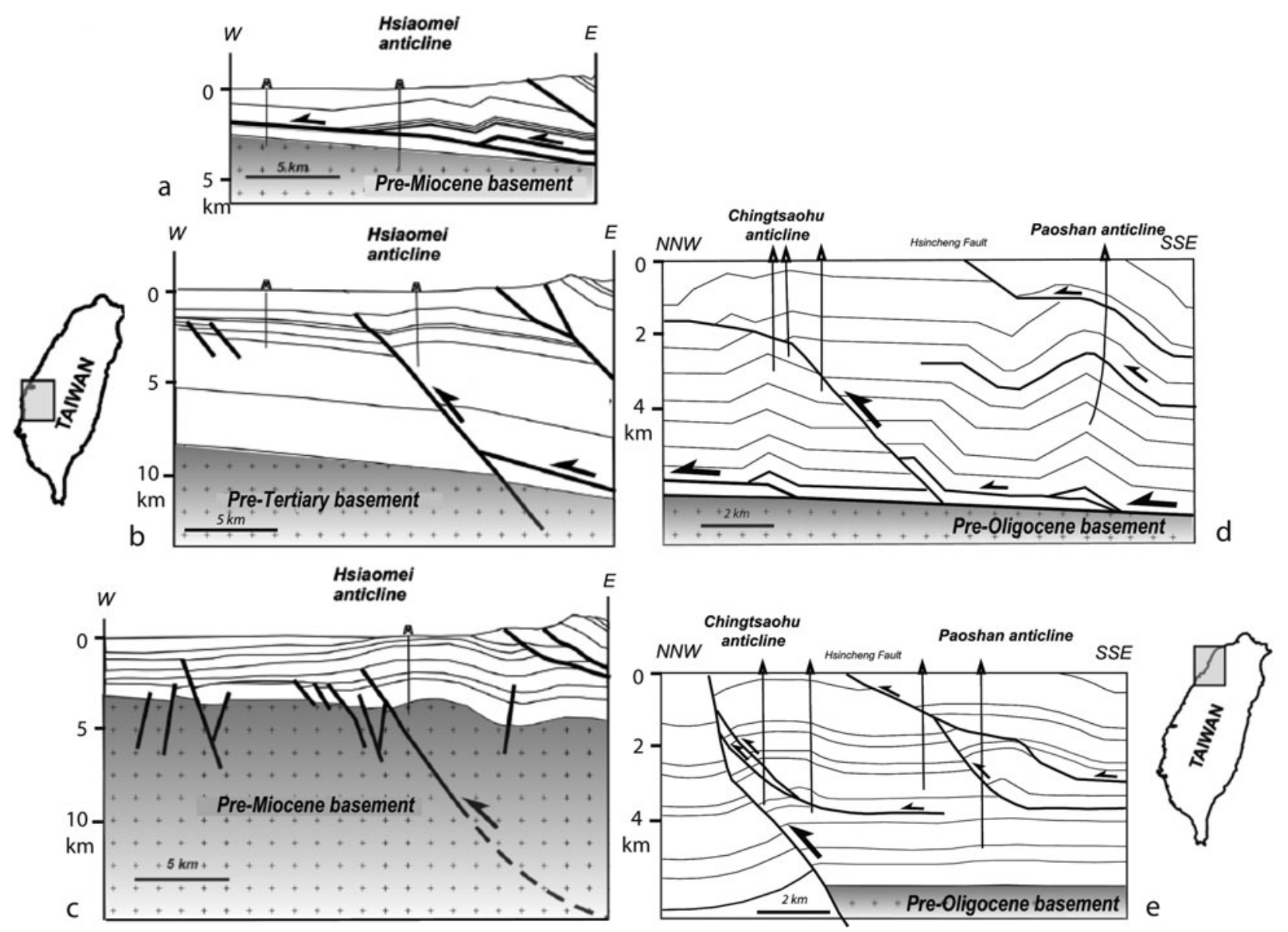

Figure 4. Examples of evolution of interpretations through time of two anticlines in the western Taiwan Foothills. Hsiaomei anticline (Central Taiwan): (a) Thin-skinned interpretation by Suppe \& Namson (1979) as a fault-bend fold; the pre-Miocene 'basement' of the Chinese continental margin is not involved in shortening. (b) Interpretation by Hung et al. (1999) as related to the reverse reactivation of the upper part of an inherited normal fault. In this view, the crystalline upper crust remains undeformed and the style of deformation is still to be considered as thin-skinned. (c) Thick-skinned interpretation by Lacombe \& Mouthereau (2006) modified after Yang et al. (2001). The anticline is related to basement-involved thrusting, i.e. the upper crust is involved in shortening. Shortening is much lower with the thick-skinned than with the thin-skinned interpretations. Chingtsaohu anticline (NW Taiwan): (d) Interpretation by Namson (1981) as a fault-bend fold. (e) Interpretation by Yang et al. (1996) as related to shallow thrusting rooting within shallow décollement levels interacting with a high-angle thrust resulting from the reverse reactivation of an inherited normal fault of the Chinese passive margin.

These examples emphasize the extent to which geological cross-sections illustrate structural interpretations that reflect combinations of available data and the model-dependent understanding of structural style at a given time. The first interpretations of surface geology, strongly driven by the thin-skinned tectonic model, were progressively challenged by inversion tectonic and thick-skinned tectonic views which still satisfy surface geological constraints and better integrate the control by the pre-orogenic structural setting. As a result, there are at present two alternative interpretations of the deformation style in the Western Foothills of Taiwan. For some authors, the imbricate thrust system is connected to a shallow, gently E-dipping décollement near the top of the Miocene or at the base of the Pliocene synorogenic sediments (e.g. Suppe 1980; Carena, Suppe \& Kao, 2002; Yue, Suppe \& Hung, 2005; Brown et al. 2012), while for others there is extensive inversion tectonics and basement-involved shortening (e.g. Lee, Chang \& Coward, 2002; Mouthereau et al.
2002; Mouthereau \& Lacombe, 2006, Yang et al. 2006; Rodriguez-Roa \& Wiltschko, 2010).

It should be noticed, however, that there is an ambiguity in the literature on what is called basement in westernmost Taiwan (Fig. 4). While some authors have defined the basement as any pre-Tertiary rocks (e.g. Ho, 1986), others have called basement any pre-Miocene (undifferentiated) rocks (e.g. Mouthereau et al. 2002; Mouthereau \& Lacombe, 2006; Fig. 4). The latter rocks, drilled in a few places in the vicinity of the Peikang Plain and beneath the Penghu Islands (Chiu, 1973), are Cretaceous to Eocene in age and are mainly composed of arkoses and arkosic sandstones, while locally some mineral assemblages point to contact metamorphism due to plutonic intrusions (Chiu, 1973). Even though these variably consolidated pre-Miocene sedimentary rocks may be lithologically and mechanically different from true crystalline rocks, they, however, remained welded to the crystalline basement, so that the bottom of the Miocene section can be 
regarded as a good proxy for the top of the true basement (for a more detailed discussion, see Mouthereau et al. 2002). As a consequence, the involvement in shortening of the pre-Miocene rocks must be considered as strongly indicative for true thick-skinned tectonics.

In Central Taiwan (see Section 3.b), recent studies have suggested that the structure and level of crustal involvement in inner parts of the belt may also significantly differ from a thin-skinned tectonic model (e.g. Wu, Rau \& Salzberg, 1997; Wu, Chang \& Wu, 2004; Gourley et al. 2007; Brown et al. 2012). This change seemingly takes place across the Shuilikeng fault, which bounds to the west the Hsuehshan Range (Camanni et al. 2014). The regional-scale structure of the Hsuehshan Range can be interpreted as a basementcored anticlinorium (Brown et al. 2012) resulting from the inversion and shortening of the former marginal Hsuehshan Basin. There, field geology (e.g. rock ages, style and amount of deformation, level of exhumation), deep seismic events and high P-wave velocities (up to $5.5 \mathrm{~km} \mathrm{~s}^{-1}$ ) at shallow depths support basementinvolved shortening and uplift of crystalline basement rocks at shallower depths than in the Western Foothills (e.g. Camanni et al. 2014).

As a result, the increasing availability of seismic profiles constrained by deep borehole data (e.g. Yang et al. 2006) led to generalized positive inversion models for the western Taiwan FTB associated with likely basement involvement in shortening. In the inner part of the Taiwan belt, structural geology combined with geophysical investigations also document basementinvolved shortening and positive inversion of former marginal basins. Seismic activity near the thrust front or eastwards, deeper than the originally inferred décollement, is likely caused by active thrust faulting distributed within the entire Eurasian continental crust (see Section 3).

\section{2.b. Apennines}

The Apennines extend from the Po Valley to the Calabrian arc and form the backbone of the Italian Peninsula (Fig. 5). The foredeep includes parts of the Po Valley in the north, part of the Adriatic Sea and, onshore in southern Italy, the Bradanic Trough. The Northern and the Southern Apennine arcs display contrasting outcropping structural levels, structural styles and kinematic histories (e.g. Satolli et al. 2014). The Northern Apennines consist of a FTB that developed during Cenozoic times, following the closure of an eastern branch of the Mesozoic Tethys Ocean (Ligurian ocean) and the collision of the European (Corsica-Sardinia block) and African (Adria block) continental margins.

During the 1980s, a thin-skinned tectonic style was proposed for the Apennines. This view was supported by seismic profiles (Bally et al. 1986; Hill \& Hayward, 1988), magnetic anomaly mapping of Italy showing a SW-dipping regional monocline in the axial Northern Apennines at a depth of 10-15 km (Arisi Rota \& Fich- era, 1987), as well as the absence of outcropping crystalline basement in the outer part of the Apennines, together with the presence of evaporites towards the base of the sedimentary cover. These thin-skinned models imply that substantial displacements have carried allochthonous sheets over buried foreland successions.

However, Coward et al. (1999) questioned the validity of these models in parts of the belt. These authors suggested that thrusts extend to depth down into the basement without significant duplication of the sedimentary sequence. The interpretation of different seismic profiles (CROP 03, Barchi, Minelli \& Pialli, 1998; Finetti et al. 2001) and the integration of surface and sub-surface datasets (Coward et al. 1999; Butler et al. 2004) led to challenging thick-skinned models of the Northern Apennines (Finetti et al. 2001; Mirabella, Barchi \& Lupattelli, 2008) that appealed to structural inheritance (Tavarnelli et al. 2004; Scisciani et al. 2010; Calamita et al. 2011). The interpretation of a recent magnetic anomaly map of the Apennines-Adriatic foreland system showed that the basement of the foreland is involved in shortening through high-angle thrust ramps likely reactivating pre-existing extensional faults (Speranza \& Chiappini, 2002). In the Umbria-Marches domain, a thick-skinned inversion tectonics model is consistent with both the limited amount of shortening and the remarkable structural elevation (Scisciani et al. 2014).

Inherited basement structures clearly exerted a strong control in the evolution of the Apennines (Tavarnelli, 1997; Coward et al. 1999; Butler, Tavarnelli \& Grasso, 2006; Scisciani, 2009; Calamita et al. 2011; Bonini, Sani \& Antonielli, 2012; Pace \& Calamita, 2014; Pace et al. 2015). Field observations and sub-surface data gathered across the Apennines revealed that the steep Jurassic to Miocene normal faults were systematically truncated and transported by Wdipping Mio-Pliocene thrusts in the Northern Apennines (Bonini, Sani \& Antonielli, 2012; Calamita, Pace \& Satolli, 2012), in the Romagna-Marche area in the Central Apennines (Coward et al. 1999; Butler et al. 2004; Butler, Tavarnelli \& Grasso, 2006) and under the Montagna dei Fiori, the Sibilini Mountains and the Gran Sasso in the Central Apennines (Tozer et al. 2002; Scisciani \& Montefalcone, 2006; Scisciani, 2009; Calamita et al. 2011).

The evolution of ideas about the structural style of the Umbria-Marches domain of the Northern Apennines has been recently re-highlighted by Scisciani et al. (2014) and is illustrated in Figure 5. The region has been classically interpreted as a thin-skinned thrust belt, with imbrication of sedimentary units detached along the Triassic evaporites, over an undeformed and buried crystalline basement (Bally et al. 1986; Fig. 5a). Later interpretations showed that at least the upper part of the basement (i.e. the Verrucano phyllites) is also involved in the main thrust sheets, leading to a thickskinned tectonic style (Calamita et al. 2000; Fig. 5b). Mirabella, Barchi \& Lupattelli (2008) alternatively proposed an imbricated array of gently dipping thrusts 


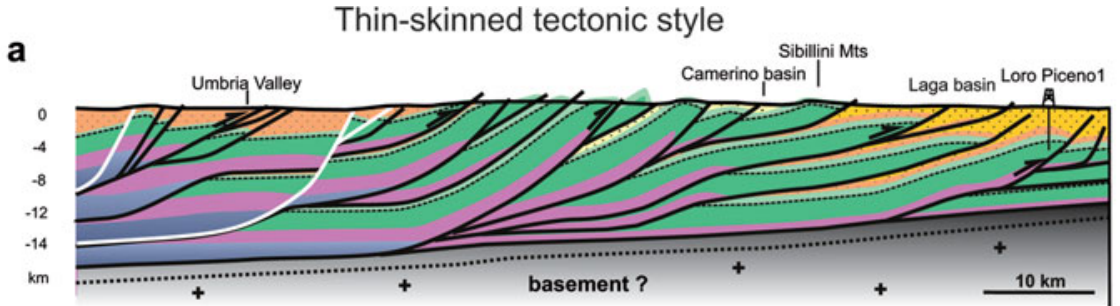

Thick-skinned tectonic style without inversion tectonics
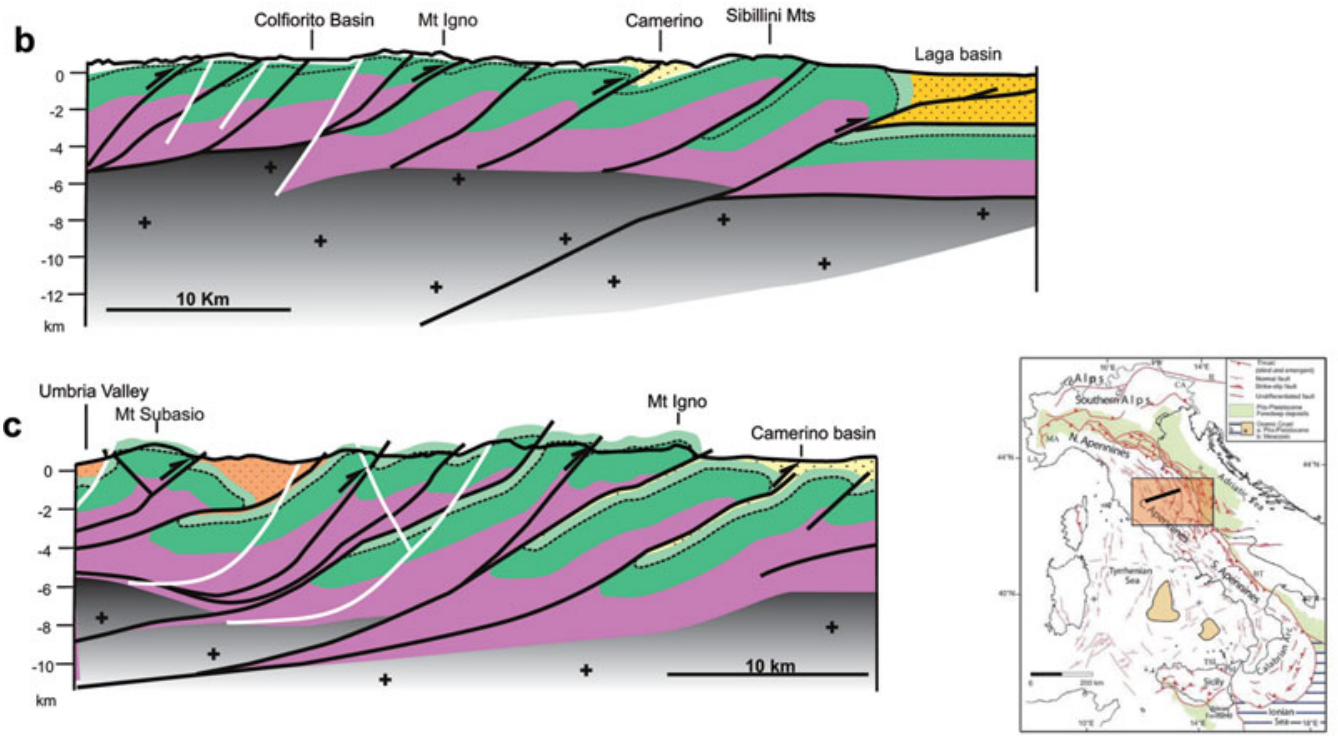

Thick-skinned tectonic style involving inversion tectonics
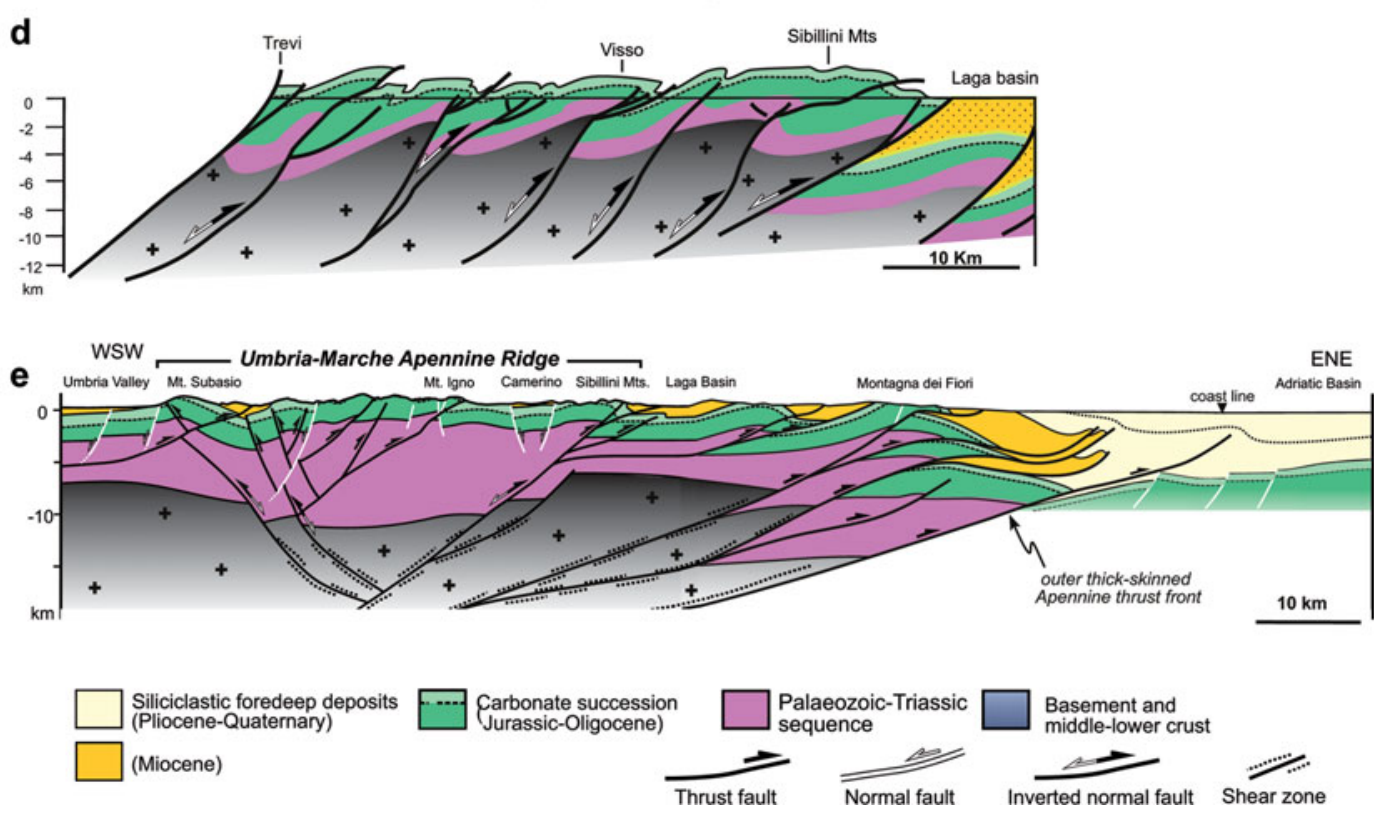

Figure 5. (Colour online) Evolution of ideas about the structural style of the Umbria-Marches domain of the Northern Apennines (modified after Scisciani et al. 2014). (a) Thin-skinned tectonic style, with imbrication of sedimentary units detached along the Triassic evaporites, over an undeformed and buried basement (Bally et al. 1986). (b) Thick-skinned tectonic style (Calamita et al. 2000). (c) Thick-skinned tectonic style with imbricated array of gently dipping thrusts cutting through basement and sedimentary cover (Mirabella, Barchi \& Lupattelli, 2008). (d) Thick-skinned tectonic style with inversion of Permo-Triassic basins with relatively steeply dipping faults (Tavarnelli et al. 2004). (e) Thick-skinned tectonic style with deep-rooted basement-involved positive inversion of pre-existing extensional basins (Scisciani et al. 2014). Note the different shortening estimates and depth of basement between cross-sections. 
cutting through basement and sedimentary cover (Fig. 5c). A thick-skinned model involving inversion of Permo-Triassic basins with relatively steeply dipping faults was proposed by Tavarnelli et al. (2004) (Fig. 5d). The most recent structural model to date, supported by recently released seismics, favours a deep-rooted basement-involved positive inversion of pre-existing extensional basins (Scisciani et al. 2014; Fig. 5e).

Recent research from the Northern Apennines has thus confirmed that thick-skinned tectonic interpretations apply to the external parts of the thrust belt. In the Marche area, simple thick-skinned inversion models honour available seismic, well and outcrop data, and clearly require far less orogenic shortening than do equivalent thin-skinned ones, e.g. $8.5 \mathrm{~km}$ of shortening (Butler et al. 2004) compared to $50 \mathrm{~km}$ for the equivalent transect using décollement-dominated, thinskinned thrusting (Bally et al. 1986). Recent seismotectonic studies also support active basement-involved shortening in the Northern Apennines and the southern Po Valley (Carannante et al. 2015; Turrini et al. 2015). In contrast, thin-skinned thrusting models are overall more suitable for the Southern Apennines. There, well data clearly demonstrate the presence of allochthonous thrust sheets transported for several tens of kilometres over mostly autochthonous $6-8 \mathrm{~km}$ thick Apulian platform carbonates. These buried carbonates are deformed by low-displacement, high-angle reverse faults involving the basement. Therefore, in the Southern Apennines, a switch from thin-skinned to thickskinned thrusting seemingly occurred as the Apulian carbonates - and the underlying thick continental lithosphere - were deformed. The Central Apennines sector lies between these two main segments of the orogen and its structural style contains elements of both thinskinned thrusting and thick-skinned inversion.

\section{2.c. Zagros (Fars province)}

The Zagros is the largest and most active collisional orogen related to Arabia/Eurasia convergence. It belongs to the Alpine-Himalayan orogenic system that resulted from the closure of the Neotethys during Cenozoic times. Collision is now thought to have initiated at $\sim 35 \mathrm{Ma}$ (e.g. Ballato et al. 2011; Mouthereau, Lacombe \& Verges, 2012) followed by intensification of deformation at $\sim 20 \mathrm{Ma}$, possibly caused by the end of underthrusting of the thin Arabian margin crust under Eurasia, and so the onset of deformation of the interior of the Arabian plate (e.g. Morley et al. 2009; Allen et al. 2013).

The Zagros folds formed in a thick (up to $12 \mathrm{~km}$ ) pile of sedimentary rocks (Stocklin, 1968; Colman-Sadd, 1978) including Palaeozoic, Mesozoic and Cenozoic strata of the former Arabian passive margin and platform. These strata were deposited in an extensional and passive margin setting during the late Palaeozoic and most of the Mesozoic periods followed by compres- sion and development of the flexural foreland basin starting in Late Cretaceous times (e.g. Koop \& Stoneley, 1982; Beydoun, Clarke \& Stoneley, 1992; Homke et al. 2009). Tertiary foreland deposits are represented by a $\sim 3 \mathrm{~km}$ thick regressive siliciclastic sequence overlying the Oligo-Miocene carbonate platform. In the Fars, the base of the sedimentary cover rocks overlies the Infracambrian-Cambrian salt (Hormuz Formation), which has a maximum thickness of 1-2 km and which acts as an extremely efficient décollement (ColmanSadd, 1978; Edgell, 1996).

In the Zagros, there is a lack of published sub-surface data from seismic refraction or reflection for depths $>$ $10 \mathrm{~km}$, so that it is difficult to have a clear image of the top of the basement (and of possible infra-Hormuz salt syn-rift Precambrian series; Husseini, 1988) and of the basement faults' pattern. Two dominant tectonic trends, respectively N-S and NW-SE (to WNW-ESE), however, exist in the Arabian Shield (e.g. Stern, 1985; Husseini, 1988). There is evidence for the continuation of such structures northwards in the former Zagros basin, and these structures were reactivated during the Cenozoic Zagros orogeny (e.g. Berberian, 1995; Talbot \& Alavi, 1996; Bahroudi \& Talbot, 2003; Ahmadhadi, Lacombe \& Daniel, 2007). The first group of basement faults are high-angle reverse faults resulting from the reactivation of basement normal faults formed in response to the Permo-Triassic rifting of Iran from Arabia. The other group of basement faults are N-Strending faults, which developed during latest Proterozoic and early Cambrian times in the Arabian basement (Beydoun, 1991). During Mesozoic times, the $\mathrm{N}-\mathrm{S}$ uplifts and basins related to this group of basement faults were intermittently reactivated (Edgell, 1992; Sherkati \& Letouzey, 2004; Sepehr \& Cosgrove, 2005). These faults are steep to vertical and are currently undergoing right-lateral strike-slip motion (Baker, Jackson \& Priestley, 1993; Berberian, 1995; Hessami et al. 2001; Sepehr \& Cosgrove, 2005).

In the Fars province, the style of deformation is characterized by a first-order remarkable train of symmetrical, regularly spaced folds of similar amplitude with a wavelength typically of $15-20 \mathrm{~km}$ and length of $100 \mathrm{~km}$ and more. Most are underlined by the limestones of the Asmari-Jahrom formations. There is a noticeable lack of macroscopic reverse faults in the cover except where basement faults have been recognized. Seismicity in the Zagros is concentrated between the deformation front in the foreland and the regional $1250 \mathrm{~m}$ contour (Jackson \& McKenzie, 1984; Talebian \& Jackson, 2004; Nissen et al. 2011). Earthquakes of $\mathrm{M} \sim 5-6$ occur in the crystalline basement up to depths of $20 \mathrm{~km}$, but no deeper.

The Zagros Fold Belt (ZFB) has been viewed, for years, as a salt-based wedge (Davis \& Engelder, 1985) in which the low topographic slope reflects the low friction décollement. In parallel, the reactivation of the basement normal faults formed in response to the rifting of Iran from Arabia as high-angle reverse faults at a depth between 10 and $20 \mathrm{~km}$ was also thought 
for a long time to be responsible for the major earthquakes along the Zagros belt (Jackson, 1980; Berberian \& King, 1981; Jackson \& McKenzie, 1984; Berberian, 1995). Mouthereau, Lacombe \& Meyer (2006) showed that the short wavelength topography $\lambda<40 \mathrm{~km}$ coincides with the 'whaleback' folds, and that this local topography is superimposed onto a much larger scale signal (overall increase of elevation from 0 to $2500 \mathrm{~m}$ across the Zagros folded belt) that results from distributed shortening at the crustal level (Fig. 6a, b, c). These authors concluded that shortening of the sedimentary cover does not create regional topography, which is rather related to thrusting within the Precambrian crystalline basement. This hypothesis is further supported by localized and long-lived deformation along several basement fault segments (e.g. Surmeh Fault and Mountain Front Fault) and the distribution of seismogenic activity within the upper brittle crust (Fig. 6e). Indeed, compressional or transpressional basement structures played a role in the deformation of the Zagros by localizing some topographic steps and major (often active) thrusts/strike-slip faults in the cover (Fig. 6c). Nissen et al. (2011) re-appraised the inferred basement earthquakes and relocated most of them in the cover, suggesting that the basement deforms by aseismic creep beneath the ZFB. They also noticed that a few large earthquakes $(\mathrm{Mw} \sim 6.7)$ can rupture the basement.

The nearly complete lack of sub-surface data, especially for depths $>10 \mathrm{~km}$ where most controversy exists over the depth to the basement and the geometry of tectonic structures, allows the drawing of very different fold and fault deep geometries that still honour surface and near-surface data. As recently re-emphasized by Allen et al. (2013), nothing argues against both thick-skinned and thin-skinned deformation occurring coevally, so it is entirely feasible that the cover deforms in relation to multiple décollements while the basement deforms by high-angle thrusting. Figure 7 illustrates the evolution of ideas (but also the ongoing debate) on the crustal-scale structure of the ZFB of the Fars province. McQuarrie (2004) proposed that the Fars segment of the FTB is completely detached on Hormuz salt (Fig. 7a) and that basement-involved thrusting occurs only in the hinterland of the orogen. This interpretation was later challenged by alternative views (Sherkati, Letouzey \& Frizon de Lamotte, 2006; Fig. 7b) considering basement thrusting responsible for major steps of the basement-cover interface and accounting for significant step-like changes in the base level of synclines across the belt below a detached faulted and folded cover. Numerical models (Fig. 6d) also showed that alone the Hormuz weak basal salt layer cannot support the topography (Mouthereau, Lacombe $\&$ Meyer, 2006). It has been therefore proposed that the origin of the topography of the Zagros would be related to deeper, crustal-scale deformation and not solely to thrust imbrication in the sedimentary cover. In this scenario, building the crustal-scale FTB requires sliding of the whole upper crust over the mostly aseismic lower crust (Mouthereau, Lacombe \& Meyer, 2006; Nissen et al. 2011). Indeed, the analysis of the topography shows that the Iranian plateau is currently expanding into the $Z F B$, as inferred by the plateau-like region in the northern ZFB and High Zagros of the Fars arc (Mouthereau, Lacombe \& Verges, 2012; Allen et al. 2013). This has led to a wealth of recent structural cross-sections of the Zagros that therefore consider that long-term shortening is achieved by cover folding above the décollement in the Hormuz salt that is cut occasionally by active basement thrusts (Blanc et al. 2003; Sherkati \& Letouzey, 2004; Molinaro et al. 2005; Sherkati, Letouzey \& Frizon de Lamotte, 2006; Mouthereau et al. 2007; Emami et al. 2010). Figure 7c illustrates the section proposed by Mouthereau et al. (2007) and Mouthereau, Lacombe \& Verges (2012) where the southern Zagros results from the propagation and stacking of deep-reverse faults rooting at depth into the middle-lower crust. Note that on this section, there is nearly no thrust within the folded Fars cover, as suggested by recent mechanical models of buckling of the detached cover including second-order décollement levels (Yamato et al. 2011). The most recent section across the Fars (Allen et al. 2013; Fig. 7d) fulfils both available structural constraints and the seismological constraint that most $(\sim 75 \%)$ earthquakes of $M$ $\sim 5-6$ are likely located within the cover and do not cut across the Hormuz Series salt (Nissen et al. 2011). Most thrusts appear to be blind and do not cut through anticlines exposed at the surface, but they do exist within the cover of the Zagros Simply Folded Belt. Basement faults have been included where there is a distinct change in structural relief on either side of an exposed structure, consistent with seismicity data that suggest that larger earthquakes in the Zagros occur in regions of greater structural relief, on faults that cut through the basement-cover boundary (Nissen et al. 2011). Allen et al. (2013) acknowledged that it is a likely minimum interpretation of basement involvement.

Interestingly, in their recent 2D thermomechanical modelling approach, Jammes \& Huismans (2012) defined the Zagros-type as a broad orogenic domain involving propagation of thrusts towards the external part of the belt (they neglect the thin-skinned FTB as a first approximation) and showed that thick-skinned deformation in this orogen is well captured by an orogenic system with weak upper and lower crusts, which leads to deformation being accommodated on a few thick-skinned crustal-scale thrusts with moderate displacement and by distributed thickening of the crust.

\section{Basement control on segmentation and along-strike variations of deformation style: Taiwan}

In the Western Foothills of Taiwan, a wealth of structural and geophysical studies show that the basement is variably involved in shortening and is responsible for along-strike variations of structural style, wedge geometry and kinematics. 

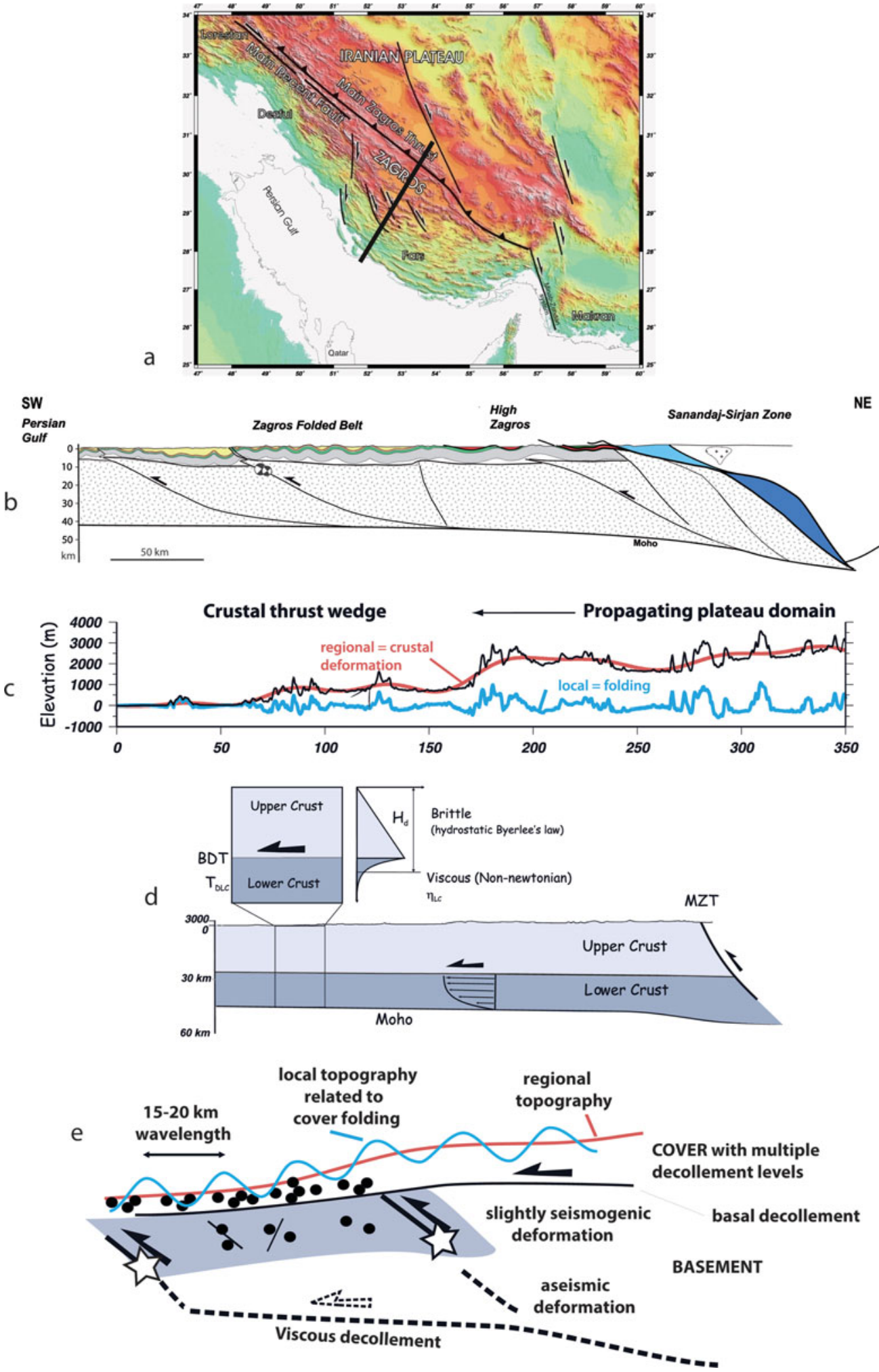

Figure 6. (Colour online) Shortening mechanisms in the cover and the basement in the Zagros (modified after Mouthereau, Lacombe \& Verges, 2012). (a) Topography (GTOPO30) and main structural features of the SE Zagros belt (Fars). (b) Cross-section of the Fars region. (c) Observed wavelength components of the topography showing the superimposition of regional topography (crustal deformation) and local fold topography (folding), modified after Mouthereau, Lacombe \& Meyer (2006). (d) Principles of the crustalscale orogenic wedge modelling of the regional topography, modified after Mouthereau, Lacombe \& Meyer (2006). (e) Interpretative sketch showing the relationships between seismogenic deformation, main decoupling levels and topography in the Zagros orogenic wedge (modified after Mouthereau, Lacombe \& Verges, 2012). 

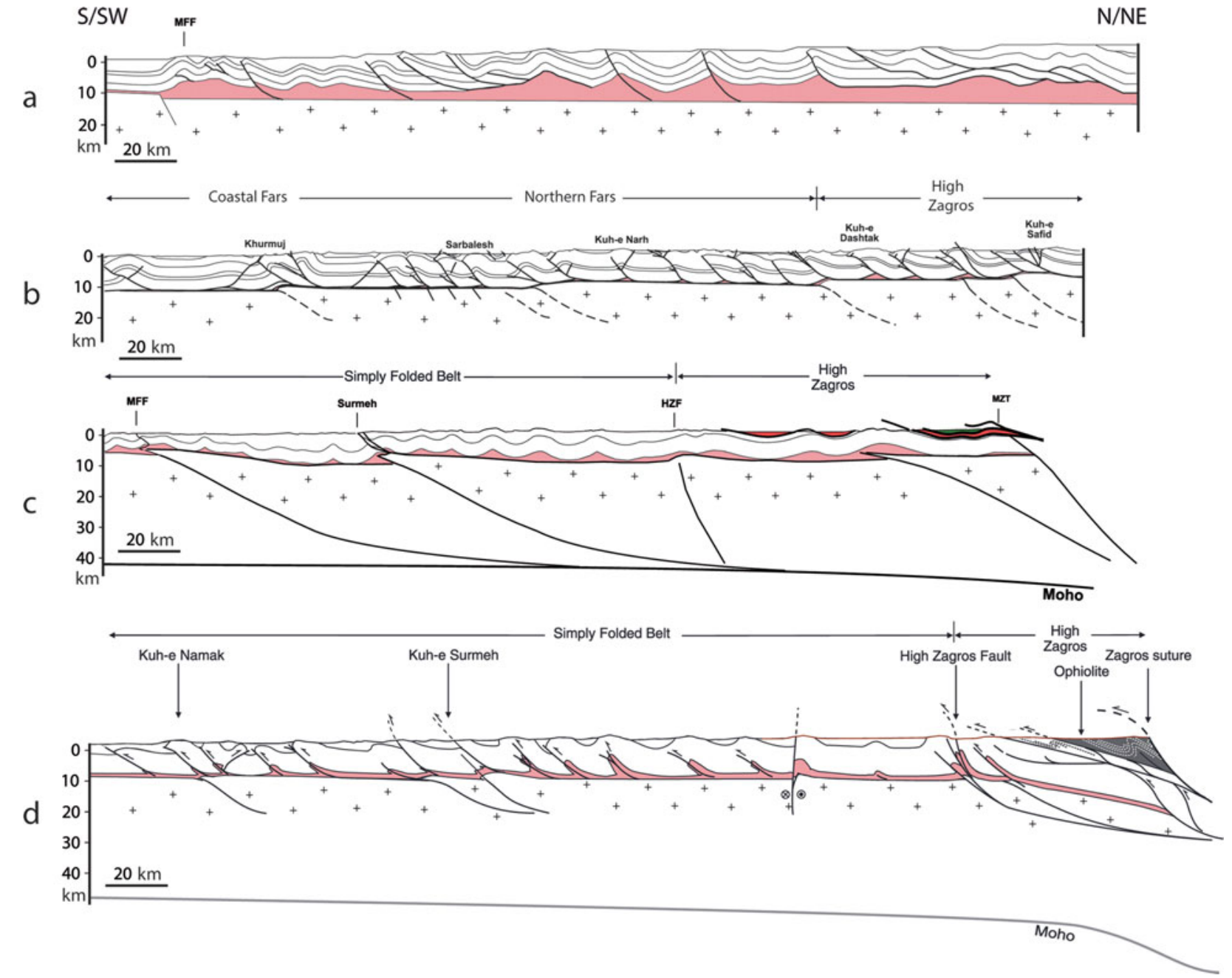

Figure 7. (Colour online) Evolution of ideas about the structural style of the Fars province roughly along the section of Figure 6. (a) Interpretation of the Fars as completely detached on Hormuz salt (McQuarrie, 2004). (b) Interpretation considering basement thrusting responsible for major steps of the basement-cover interface and accounting for significant step-like changes in the base level of synclines below a detached faulted and folded cover (Sherkati, Letouzey \& Frizon de Lamotte, 2006). (c) Interpretation with long-term shortening being achieved by cover folding (buckling) above the Hormuz salt that is cut occasionally by active basement thrusts (Mouthereau et al. 2007; Mouthereau, Lacombe \& Verges, 2012); the Fars thus results from the propagation and stacking of deep-reverse faults rooting at depth into the middle-lower crust. (d) Interpretation by Allen et al. (2013) with most cover thrusts as blind and not cutting through exposed anticlines, and a few basement faults associated with changes in structural relief and along which large earthquakes occur. MFF - Mountain Front Fault; HZF - High Zagros Fault; MZT - Main Zagros Thrust.

\section{3.a. NW Taiwan}

In NW Taiwan, the Taihsi Basin corresponds to a synrift Palaeogene basin trending ENE-WSW, i.e. parallel to the regional trend of the continental margin. It is bounded to the north by the Kuanyin High and to the south by the Peikang High (Fig. 8), two major basement promontories that were only slightly affected by extension. Deposition of a thick Oligocene-Miocene sequence occurred during a second episode of extension that took place after rifting and prior to collision. Both the pre-Miocene basement of the basin and the overlying Neogene sedimentary cover have been uplifted, making the Taihsi Basin an inverted basin (Huang, Chen \& Chi, 1993; Shen et al. 1996).

Offshore, most features strike $\mathrm{N} 070^{\circ}$, at a high angle to the structural grain of the belt: they correspond either to Palaeogene to Miocene normal faults which probably extend down to the Mesozoic basement, or to high- angle thrusts which originated from the reactivation of the previous normal faults (Yang et al. 1994, 1997). The $\mathrm{N} 070^{\circ}$ faults extend onshore as S-dipping highangle thrusts (Fig. 8a1). These high-angle thrusts result from the compressional reactivation of pre-existing normal faults of the margin (Huang, Chen \& Chi, 1993; Yang et al. 1996). Oblique en échelon folds along these high-angle thrusts as well as along-strike variations in magnitude and sense of offset additionally indicate a significant amount of right-lateral wrench movement (Huang, Chen \& Chi, 1993; Lee et al. 1993; Shen et al. 1996).

The pattern of folds and W-verging imbricated thinskinned thrust sheets of the arcuate FTB of NW Taiwan formed in relation with various décollement levels recognized within both the pre-collisional Palaeogene to Miocene deposits and the synorogenic Plio-Pleistocene formations. 

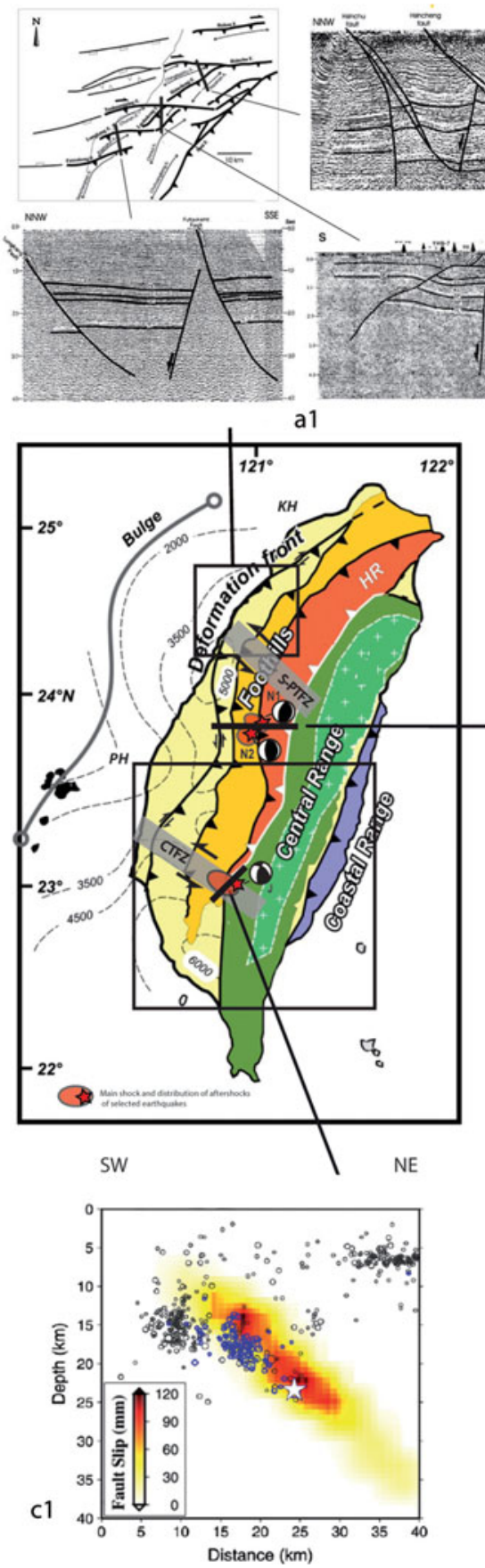

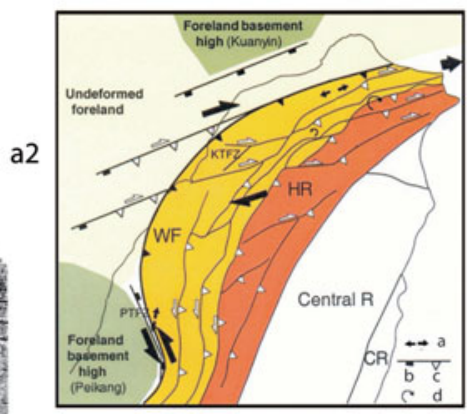

a3

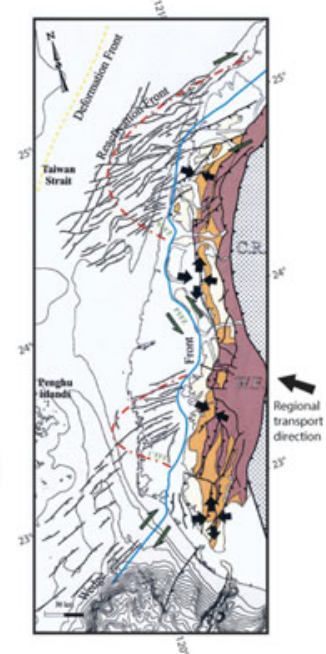

E
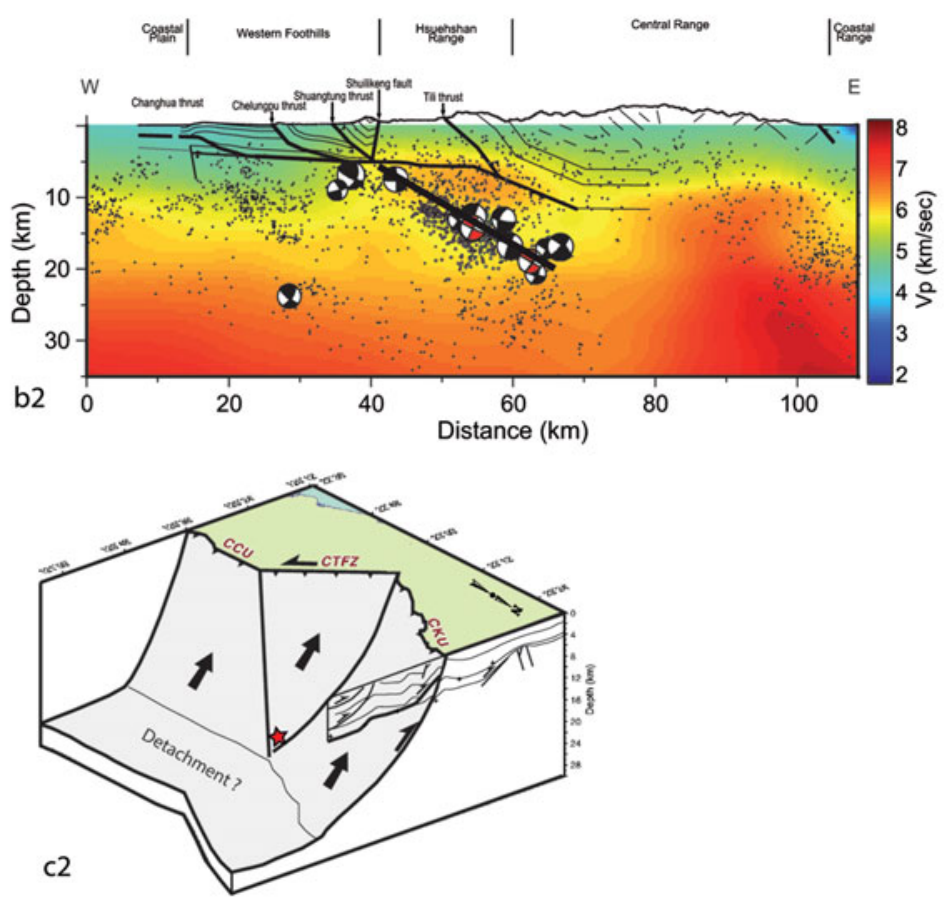

Figure 8. (Colour online) The Taiwan orogen. Insert: Main structural units of Taiwan. Isobaths in metres. PH, KH - Peikang/Kuanyin Highs; HR - Hsuehshan Range; S-PTFZ - Sanyi-Puli Transfer Fault Zone; CTFZ - Chishan Transfer Fault zone; J - 2010 Mw 6.2 Jiashian earthquake; N1 and N2 - 27 March ML 6.2 and 2 June ML 6.5 2013 Nantou earthquakes. (a1) Seismic evidence of reactivation of inherited basement faults from the Chinese continental margin in NW Taiwan (data after Yang et al. 1996, 1997). (a2) Kinematic model of the NW Taiwan arcuate belt (modified after Lacombe et al. 2003). The curvature of the basin-controlled salient is accommodated to the south by the Pakua Transfer Fault Zone (PTFZ) and to the north by a diffuse oblique ramp (the Kuanyin Transfer Fault Zone, KTFZ) where high-angle wrench-thrust faults inherited from the inversion of normal faults guided the emplacement of thin-skinned low-angle thrusts. WF - Western Foothills; HR - Hsuehshan Range; Central R - Central Range; CR - Coastal Range; a - local extension accommodating curvature along the limbs of the arc; $b$ - normal fault of the margin; $c$ - high-angle wrench-thrust fault; $d$ - vertical axis rotations. (a3) Structural sketch map of the Taiwan thrust belt, showing locations of the different types of thrust-belt fronts in western Taiwan and their relationship with the shape of the pre-Miocene basement. The along-strike variation of structural style is correlated with along-strike variations in the main stress regimes and demonstrates the evolution from prominent strike-slip regimes to purely compressional regimes especially in areas where basin inversion occurs. (b) Seismological evidence for crustal shortening in western Central Taiwan: (b1) Crustal cross-section modified after Brown et al. (2012) and Camanni et al. (2014). (b2) Crustal cross-section modified after Chuang et al. (2013). The red beach balls denote the Nantou main shocks, and the black beach balls denote the Chi-Chi aftershocks and other ML > 5.5 events. (c) Seismological evidence of crustal shortening and a deep décollement in SW Taiwan. (c1) Distribution with depth of mean slip and aftershocks following the 2010 Jiashian earthquake (blue circles) together with background seismicity (grey circles). White star denotes the location of the 2010 Jiashian earthquake main shock (modified after Ching et al. 2011; Rau et al. 2012). (c2) Conceptual tectonic model for southern Taiwan inferred from the 2010 Jiashian earthquake. Red star denotes the location of the main shock. CCU - Chaochou fault; CKU - Chukou fault; CTFZ - Chishan Transfer Fault Zone (modified after Ching et al. 2011). 
The obliquity of the $\mathrm{N} 120^{\circ}$ regional transport direction with respect to the orientation of the inherited extensional structures of the margin localized areas dominated by frontal contraction and those dominated by wrench deformation (Fig. 8a3). Frontal contraction occurred against the Peikang High, which acted as a buttress for the propagating thrusts (Lu et al. 1998; Mouthereau et al. 1999). In contrast, the northern edge of the Peikang High as well as the southern edge of the Kuanyin High, which are associated with significant basement offset and changes in thickness of sedimentary formations, have localized 'conjugate' lateral/oblique ramps that guided thrust emplacement and accommodated curvature of the NW Taiwan salient. The structural and kinematic model of Figure 8a2 involves the oblique reactivation of the normal faults inherited from the Palaeogene-Neogene extensional history of the margin and their interaction with the thrusts of the Plio-Pleistocene Taiwan orogenic wedge. $\mathrm{N} 070^{\circ}$-trending normal faults were first obliquely reactivated as high-angle thrusts with a right-lateral wrench component in response to the far-field transmission of orogenic stresses during the early stage of the Plio-Pleistocene arc-continent collision. Thrust sheets related to the growing orogenic wedge then initiated in relation to shallow décollements in the cover and propagated in a nearly $\mathrm{N} 110-120^{\circ}$ transport direction, i.e. obliquely towards the reactivated normal faults. In a second stage, the inverted normal faults were used as lateral/oblique ramps for the low-angle thrusts, which continued to propagate and consequently turn their strike northwards into a direction parallel to the $\mathrm{N} 070^{\circ}$ strike of the high-angle thrusts (Fig. 8a1, a2; Lacombe et al. 2003).

The NW Taiwan arc is therefore mainly a basincontrolled salient where deformation was accommodated by both thin-skinned shallow thrusts and basement faults, and therefore where both the cover and the basement are involved in shortening. The arc clearly developed in the portion of the foreland basin that was initially thicker (the Taihsi Basin) (Lacombe et al. 2003; Fig. 8a2). This demonstrates also the 'passive' control on the development of the NW Taiwan salient exerted by the distribution of the basement highs and the related along-strike variations in the pre-orogenic basin thickness.

\section{3.b. North Central Taiwan}

In north Central Taiwan, thin-skinned deformation predominates in the outermost (frontal) unit, whereas basement-involved thrusting likely played a major role more to the east. To this respect, and although challenging interpretations exist (Yue, Suppe \& Hung, 2005), the Chelungpu-Sani fault has been interpreted by Mouthereau \& Lacombe (2006) as an inverted normal fault.

A number of geophysical observations suggest that deeper levels of the crust are involved in the mountainbuilding process east of the frontal units. Seismicity in Taiwan extends well below the proposed décollement depth (Carena, Suppe \& Kao, 2002) and thick crust underlying high topography supports active deformation of deeper crust, hence basement-involved, thick-skinned models (e.g. Lacombe \& Mouthereau, 2002; Mouthereau \& Lacombe, 2006).

The 27 March ML 6.2 and 2 June ML 6.52013 Nantou earthquakes nucleated below the shallow décollement within the deep 21 September 1999 Chi-Chi aftershock clusters. Chuang et al. (2013) proposed that the two earthquakes occurred on essentially the same fault plane, the so-called Nantou fault, and that the majority of the combined slip was released between depths of 5 and $20 \mathrm{~km}$ (Fig. 8b2). These authors proposed that the Nantou earthquakes as well as the Chi-Chi aftershocks reflect a deep extension of the shallow ramp fault structure into the middle crust.

Contrasting interpretations of the Nantou fault have been proposed: (1) it could be a deep extension of the Shuilikeng fault (Brown et al. 2012; Camanni et al. 2014); in this interpretation, the Shuilikeng fault is an active deep-seated main structure of the Taiwan orogen (Fig. 8b1). Westwards, a subhorizontal cluster of seismicity can be interpreted as the décollement to the imbricate stack mapped there, linking it to the thickskinned deformation east of the Shuilikeng fault margin of the Hsuehshan Basin in Eocene time (Camanni et al. 2014); (2) The Nantou fault may link to the shallow décollement that partially ruptured during the Chi-Chi earthquake based on the Chi-Chi aftershock distributions. The bottom of the Nantou fault might link to the deep Chi-Chi aftershock cluster; (3) if the Nantou fault has no direct link with any of the shallow ramp faults overlying the décollement, the Nantou fault can well be a newly developed sub-surface structure (Fig. 8b2) (Chuang et al. 2013).

Seismicity deeper than the proposed Taiwan décollement thus exists in north Central Taiwan, including the deep Chi-Chi aftershock cluster at depths between 20 and $30 \mathrm{~km}$. It is therefore indisputable that a significant part of the shortening across Taiwan is accommodated by slip on deep fault systems. The existence of the deep Nantou fault as well as a lack of a clear seismic signature of the décollement beneath the Central Range (e.g. Wu, Chang \& Wu, 2004; Gourley et al. 2007; Wu et al. 2008; Brown et al. 2012) clearly argue against a structural architecture across Taiwan being fully accounted for by thin-skinned tectonics above a main décollement (e.g. Suppe, 1980; Carena, Suppe \& Kao, 2002; Yue, Suppe \& Hung, 2005), and support that deep structures play an important role in accommodating regional compressional deformation across the active collisional belt (Brown et al. 2012; Chuang et al. 2013; Camanni et al. 2014).

\section{3.c. South Central Taiwan}

The Chishan Transfer Fault Zone (CTFZ) has been interpreted as a major transverse domain that marks the transition from a region of basement-involved tectonics 
to the north (Deffontaines et al. 1997; Mouthereau et al. 2002; Mouthereau \& Lacombe, 2006) to the area of tectonic escape with a thin-skinned style (Lacombe et al. 2001). In the field the CTFZ strikes $\mathrm{N} 130^{\circ} \mathrm{E}$ and crops out as a more than $20 \mathrm{~km}$ long and $1 \mathrm{~km}$ wide elongated bulge, containing several closely spaced NW-SE shear zones associated with a left-lateral sense of transpressive shear (Deffontaines et al. 1997; Lacombe et al. 1999). In map view, the CTFZ acts as a lateral ramp connecting stepping thrusts, the Chaochou fault and the Chukou fault.

In south Central Taiwan, basin inversion and basement-involved shortening predominate in the outermost units (Mouthereau et al. 2002; Mouthereau \& Lacombe, 2006). As in NW Taiwan, the structure of folds and thrusts beneath the Coastal Plain results mainly from inversion of inherited normal faults. The development of fold-and-thrust structures in this domain is strongly influenced by the presence of an inherited pre-orogenic trough, namely, the Tainan basin. In a somewhat analogue way to the Taihsi Basin northwards, the inversion of the intra-marginal Tainan basin leads to the development of a dominant thick-skinned deformation style.

The $2010 \mathrm{Mw} 6.2$ Jiashian earthquake (Ching et al. 2011; Rau et al. 2012; Wen et al. 2012; Fig. 8c2) provided direct seismological evidence of activity of the CTFZ. The position and strike of the inferred fault plane suggests that the earthquake occurred on the southeastern extension of the CTFZ. The mismatch between the inferred fault top edge and the trace of the CTFZ might be explained either by along-strike bending of the surface trace of the southeastern extension of the CTFZ towards the SE or by a change in dip of the fault plane at depth such that the upper section of this fault has a larger dip angle than the deeper part that ruptured in the earthquake (Ching et al. 2011).

For the 2010 Jiashian earthquake, the focal depth is about $23 \mathrm{~km}$ and the inferred slip is confined to the 10-25 km depth range (Ching et al. 2011; Rau et al. 2012; Fig. 8c1). Together with the Nantou earthquakes in north Central Taiwan, this implies that the depth of seismicity and the depth of the likely active basal décollement are much deeper than the previously proposed $\sim 10 \mathrm{~km}$ depth inferred by the distribution of small earthquakes (Carena, Suppe \& Kao, 2002). Regardless of whether this earthquake reflects motion on a reactivated passive margin structure (Huang et al. 2013) or a lateral ramp of a basal décollement (Ching et al. 2011), or even whether the earthquake may involve two rupture planes (Lin et al. 2015), it strongly supports the idea that the whole Chinese crust is involved in shortening.

To conclude on Taiwan, there is a wealth of evidence provided by structural geology, magnetotelluric sounding, earthquake hypocentre distribution and seismic tomography that that rocks below the basal thrust proposed by Carena, Suppe \& Kao (2002), including the pre-Tertiary crystalline basement, are involved in collisional shortening. Many works have documented steeply dipping faults that penetrate down into the middle and perhaps even the lower crust, many (if not all) of them being inherited from the extensional history pre-dating the Taiwan orogeny. Pre-existing structures of a continental margin therefore play a very important role in many aspects of the evolution of an orogen during mountain building. The young Chinese continental margin was affected by a rapid succession of thermal and extensional events since Palaeogene times. These events caused a pre-orogenic structural segmentation of the margin, outlined for instance by marginal basins separated by basement highs. This segmentation pattern was presumably responsible for significant rheological heterogeneities in the crust/lithosphere along the Chinese continental margin prior to the collisional event. Subsequent shortening has been largely controlled by these pre-existing heterogeneities and the positive inversion of the former extensional basins (e.g. Wu, Rau \& Salzberg, 1997; Mouthereau et al. 2002; Mouthereau \& Petit, 2003; Mouthereau \& Lacombe, 2006; Hwang et al. 2007; Byrne et al. 2011; Brown et al. 2012; Camanni et al. 2014, 2015). Along-strike structural changes in the Taiwan belt are associated with variations in the recent kinematics of the deformation in the frontal areas, which reflect local effects such as frontal contraction and lateral movement in response to indentation by the basement buttresses (Fig. 8a3).

\section{Along-strike variations of deformation style and shortening: western Alps and Pyrenees}

\section{4.a. The External Crystalline Massifs of the western Alps}

The Alps result from the closure of the Ligurian oceanic domain, the subduction of which started during Late Cretaceous times and lasted until late Paleocene to early Eocene times. Oceanic subduction was followed by continental subduction during middle to late Eocene times (e.g. Dora Maira; Duchene et al. 1997; Rubatto \& Hermann, 2001; Oberhänsli et al. 2004), then collisional crustal thickening that started during Oligocene times (e.g. for the western Alps; Corsini, Ruffet \& Caby, 2004; Rolland et al. 2008; Simon-Labric et al. 2009; Sanchez et al. 2011; Bellanger et al. 2014), especially with shortening of the external Alps, in the External Crystalline Massifs (ECMs). The Alpine ECMs are composed of the Argentera-Mercantour in the southwestern Alps, the Oisans, Grandes Rousses, Belledonne, Mont Blanc and Aiguilles Rouges massifs in the western Alps, and the Aar and Gothard massifs in the central Alps (Fig. 9a).

At the latitude of Oisans, the total amount of shortening across the external zone is about $28 \mathrm{~km}$ (Fig. 9c3), including $11.5 \mathrm{~km}$ accommodated within the ECMs (Bellahsen et al. 2012) where the Mesozoic metasedimentary cover is not significantly detached from the Variscan basement. Disharmonic folding occurs in the cover, especially above $\mathrm{W}$-verging basement shear zones (see Section 7.b). Shortening of these basement/cover units occurred under greenschist-facies 
a
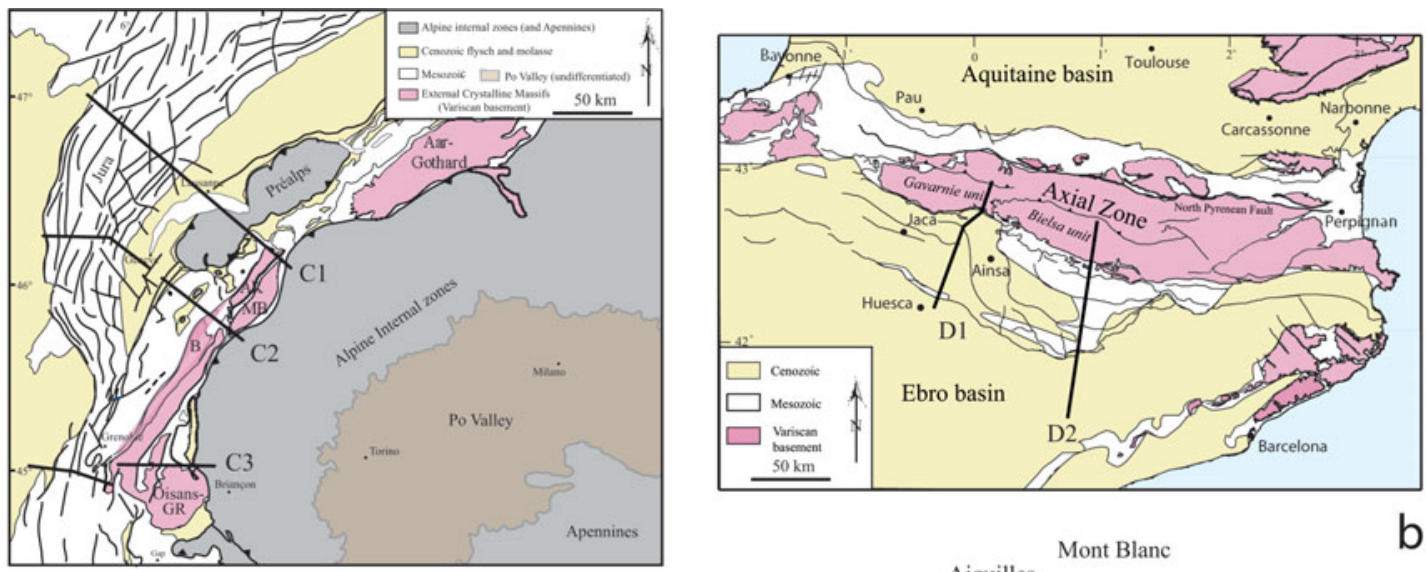

c1

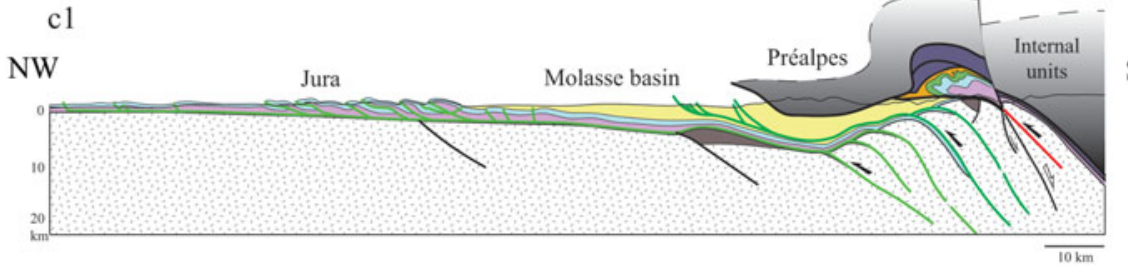

SE

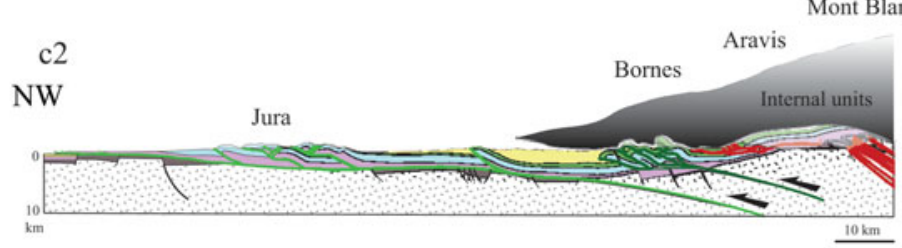

SE

C

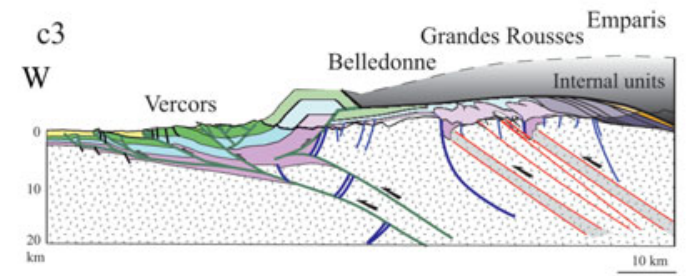

E

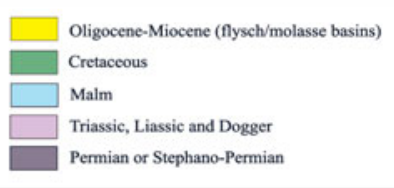

d1

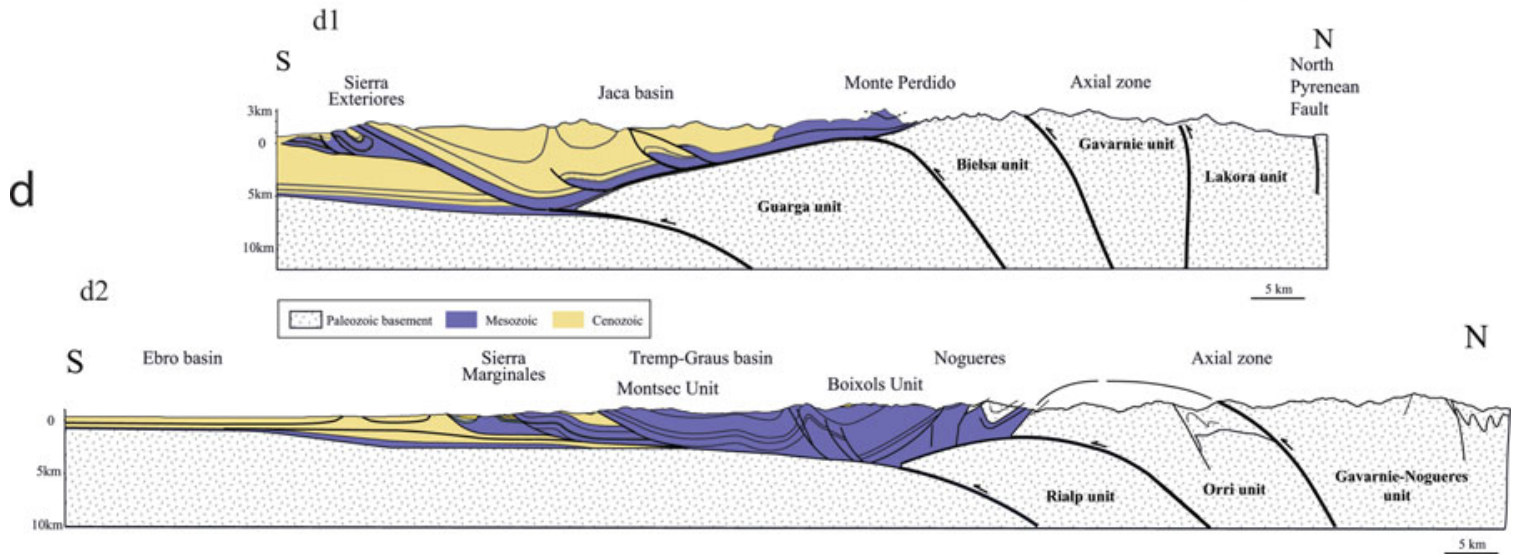

Figure 9. (Colour online) (a) Structural sketch of the western Alps. AR - Aiguilles Rouges; MB - Mont Blanc; GR - Grandes Rousses; B - Belledonne. (b) Structural sketch of the Pyrenees. NPZ/SPZ - North/South Pyrenean Zone. (c) Structural sections across the external zones at the latitude of the northern Mont-Blanc ECM (c1), of the southern Mont-Blanc ECM (c2) and of the Oisans ECM (c3) (modified after Bellahsen et al. 2014). Note the along-strike change in accommodation of basement shortening from c1 to c3. (d) Structural sections across the Axial Zone of the Pyrenees and the southern Pyrenean FTB. (d1) Modified after Jolivet et al. (2007). (d2) Modified after Mouthereau et al. (2014). 
conditions (3-4 $\mathrm{kb}$ and $300-350^{\circ} \mathrm{C}$ : Jullien \& Goffé, 1993; Crouzet, Menard \& Rochette, 2001; SimonLabric et al. 2009); their exhumation started at least at $27 \mathrm{Ma}$ from zircon fission track (ZFT) ages (van der Beek et al. 2010) for the Meije massif (NE Oisans) and at least at $24 \mathrm{Ma}$ from thermopalaeomagnetism (Crouzet, Menard \& Rochette, 2001) for the Grandes Rousses massif; apatite fission track dating (AFT) showed that these massifs cooled through the $110^{\circ} \mathrm{C}$ isotherm at about 3-8 Ma (Vernon et al. 2008). In the Mont Blanc massif (Fig. 9b), basement deformation by anastomosed steep transpressional shear zones occurred from 22 to $15 \mathrm{Ma}$ (Rolland et al. 2008) at around $400^{\circ} \mathrm{C}$ and $5 \mathrm{~kb}$ (Rolland et al. 2003). Recently, ages of $29 \mathrm{Ma}$ were obtained in central Mont Blanc shear zones (Cenki-Tok et al. 2013), suggesting that the onset of the shortening could be older. For the Aiguilles Rouges massif, the structural interpretation of Burkhard \& Sommaruga (1998) suggests that the upper Aiguilles Rouges basement thrusts were active during deposition of the so-called Upper Freshwater Molasse, i.e. since $16 \mathrm{Ma}$. In both the Mont Blanc and the Aiguilles Rouges massifs, most ZFT ages are about 8-15 Ma; AFT ages are about 3-8 Ma (Vernon et al. 2008). In the Aar massif, the main shearing event occurred between 17 and $21 \mathrm{Ma}$ at $400-450^{\circ} \mathrm{C}$ and $6 \mathrm{~kb}$ (Challandes, Marquer \& Villa, 2008) or 20-22 Ma (Rolland, Cox \& Corsini, 2009) with W-verging kinematics and was followed by reverse to dextral shear zones at 12-14 Ma (Rolland, Cox \& Corsini, 2009). Late brittle deformations occurred from 9-5 Ma (Kralik et al. 1992) and probably until $3 \mathrm{Ma}$ (Hofmann et al. 2004).

In the frontal thin-skinned FTBs (Vercors, Chartreuse, Bauges, Bornes, from south to north), the age of shortening is about middle Miocene (e.g. Burkhard \& Sommaruga, 1998). The Jura is slightly younger and developed from Serravallian until early Pliocene times (see Section 5). In these massifs, the thrusts root into a décollement located within the upper Triassic or Liassic series (Deville et al. 1994; Philippe, Deville \& Mascle, 1998).

Localization and style of basement-involved deformation vary along the strike of the western Alpine arc (Fig. 9a). In the Oisans (Fig. 9c, section c3), basement was shortened in a distributed way during Oligocene times (Simon-Labric et al. 2009; Bellahsen et al. 2014; Bellanger et al.2015) before deformation localized on the frontal ramp that activated the Vercors shallow décollement (Deville et al. 1994). Deformation there was thus first characterized by accretion and thrust stacking below the wedge (distributed underplating) without wedge widening, and later by frontal accretion, hence orogenic wedge widening during Miocene times. In contrast, along the Mont Blanc-Aiguilles Rouges section, basement shortened by underplating below the internal units during Oligo-Miocene times (Leloup et al. 2005; Rolland et al. 2008). During late Miocene - early Pliocene times, basement units were still underplated (lower Aiguilles Rouges) while a very wide cover do- main was accreted in the frontal parts (e.g. Jura and Molasse Basin) with the activation of large basement thrusts (Burkhard \& Sommaruga, 1998).

Moreover, both amounts of shortening and shortening across the entire external zone increase from the Oisans section to the Mont Blanc section (Fig. 9c). The increase in the amount of shortening is most likely due to a wider inherited Mesozoic basin in the north (Ultra-Helvetic/Valaisan; Bellahsen et al. 2014). However, the increase in the shortening values probably has a rheological explanation. Along the Mont Blanc section, basement shortening remains localized, leading to stacking of basement slices (Fig. 9c, section c1), while it is distributed far towards the foreland along the Oisans section (Fig. 9c, section c3); this can be related to the rheology of the crust during collision, the more buried and thermally weakened crust at the latitude of Mont Blanc $\left(400^{\circ} \mathrm{C}, 5 \mathrm{~kb}\right)$ being more prone to localized shortening at the orogen scale (see Section 8).

\section{4.b. Pyrenees}

The Pyrenean mountain belt results from the inversion of a rifted and hyper-extended Mesozoic crustal domain located in the present-day North Pyrenean Zone (NPZ) (Roure et al. 1989; Beaumont et al. 2000; Verges, Fernandez \& Martinez, 2002; Jammes et al. 2009; Lagabrielle, Labaume \& de Saint Blanquat, 2010). The convergence started during Late Cretaceous times and lasted until Oligocene times (e.g. Verges, Fernandez \& Martinez, 2002). During the collision, N-verging crustal thrusts deformed the NPZ, while S-verging thrusts affected the Axial Zone and the South Pyrenean Zone (SPZ; Fig. 9b, d). The Axial Zone is composed of a few basement units, namely the Lakora, Gavarnie, Bielsa-Millares and Guarga in the western part and Gavarnie/Nogueres, Orri and Rialp in the east (Fig. 9b). These units form the so-called Pyrenean axial antiformal stack (Fig. 9d).

In the western part of the Axial Zone, the Lakora thrust was active above the future Gavarnie unit during Lutetian times (Teixell, 1996) during the deposition of the Hecho Group turbidite series (Labaume, Seguret \& Seyve, 1985) in the Jaca basin (Fig. 9b, d). During late Eocene - early Oligocene times, the Gavarnie thrust affected the basement, triggering the southward migration of the foreland basin. Finally, during Oligocene times, the Guarga unit was emplaced in the basin. Further east, in the Lakora/Gavarnie unit, reverse shear zones were dated at about 47-48 Ma (Wayne \& McCaig, 1998). In the footwall of the Gavarnie thrust, the Bielsa-Millares unit was part of a larger basement unit, namely the Guarga unit (Teixell, 1996), the emplacement of which tilted the Lutetian Hecho turbidites in the Jaca basin (Labaume, Seguret \& Seyve, 1985; Teixell, 1996) probably during late Oligocene times (Jolivet et al. 2007). In the central Axial Zone, cooling history is well documented: in the Gavarnie unit, ZFT ages are about $50 \mathrm{Ma}$ (Sinclair et al. 2005), AFT ages about 26 to $45 \mathrm{Ma}$ (Fitzgerald et al. 1999; 
Sinclair et al. 2005) and UTh/He on apatites between 17 and $37 \mathrm{Ma}$ (Gibson et al. 2007). In the Orri unit, below the Gavarnie unit, AFT ages range between 17 and $35 \mathrm{Ma}$ (Morris, Sinclair \& Yelland, 1998; Fitzgerald et al. 1999; Sinclair et al. 2005; Gibson et al. 2007), and $\mathrm{U}-\mathrm{Th} / \mathrm{He}$ ages on apatites range between 10 and $35 \mathrm{Ma}$ (Gibson et al. 2007). These ages show an extremely rapid exhumation during early Oligocene times, following and followed by a slower exhumation during Eocene and late Oligocene times (Fitzgerald et al. 1999).

Because the Pyrenees result from the inversion of a former rifted domain, fault inversion is a common feature of their structural style in the Axial Zone (Saura \& Teixell, 2006; Lagabrielle, Labaume \& de Saint Blanquat, 2010), the NPZ (Biteau et al. 2006; Lagabrielle, Labaume \& de Saint Blanquat, 2010) or, in the eastern extension of the Pyrenees, the Provence domain (Roure \& Colletta, 1996; Lacombe \& Mouthereau, 2002; Espurt et al. 2012; Bestani et al. 2015). In contrast, in the southern Pyrenees, inherited faults were not widely reactivated but were truncated by thrusts (Fernandez et al. 2012) or simply localized frontal thrusts, as for the Boixols unit, by causing important sedimentary thickness variations on both sides of the thrust zones (Garcia-Senz, Muñoz \& McClay, 2000).

$P-T$ conditions of deformation in the Pyrenees were very different from the western Alps, especially in term of burial, which remained much shallower. However, the striking similarity in term of basement shortening style between sections $\mathrm{c} 1$ and $\mathrm{d} 2$, and sections $\mathrm{c} 2$ and $\mathrm{d} 1$ in Figure 9 suggests that along-strike variations in the structural style may also be controlled by differences in crustal thermicity, with temperatures lower to the west than to the east. This is consistent with the maximum temperature recorded by the Raman Spectroscopy on Carbonaceous Material technique in the NPZ and related to the Cretaceous extension and mantle denudation, higher to the east than to the west (Clerc \& Lagabrielle, 2014). In this perspective, the crust was hotter and weaker in the east, where, as a consequence, shortening was more localized than in the west, although the total shortening is similar.

Low-temperature thermochronology supports that the high geothermal gradient lasted 30-50 Ma after extension, hence during convergence in the NPZ (Vacherat et al. 2014) and probably also in the Axial Zone, which likely favoured basement-involved shortening. Note that the formation of basement antiformal stacks (similar to the formation of the Nogueres, Orri and Rialp thrust sheets in the eastern Pyrenees and to the Gavarnie and Guarga thrust sheets in the western Pyrenees; Fig. 9d1, d2) is well reproduced by 2D thermomechanical modelling of an orogenic system in which the development of thrusts rooted in the buttress creates a stacking of basement rocks and the lower crust is thick $(>15 \mathrm{~km})$ (Jammes \& Huismans, 2012).

\section{Evolving tectonic style from thin-skinned to thick-skinned through time: the Jura}

The Jura is an arcuate foreland FTB formed by folding and faulting of the Mesozoic cover detached from the Palaeozoic basement along Triassic evaporites as a result of crustal stacking in the Alpine ECMs (e.g. Philippe et al. 1996; Burkhard \& Sommaruga, 1998; Bellahsen et al. 2014; Fig. 10a, b).

The Jura has for a long time been considered a typical thin-skinned FTB. At its northern and western rims, respectively, the Jura belt overthrusts the southern Rhinegraben and the eastern Bresse graben, two branches of the Oligocene West European Rift System. The deposition and pinching out of the Triassic evaporites, together with the pre-orogenic Oligocene extensional structures that caused offsets of the décollement prior to shortening, strongly controlled not only the emplacement and geometry of the thin-skinned outermost thrusts and folds, but also the kinematics of the entire FTB. The formation of the thin-skinned Jura FTB is usually considered a rather short-lived event, starting around 14-11 Ma and terminating at nearly 4-3 Ma (e.g. Becker, 2000).

On the basis of reflection seismic profiles and crosssection balancing, inversion of Permo-Carboniferous grabens (Fig. 10d) and reactivation of their bounding normal faults underneath the Jura and post-dating thinskinned folding and thrusting have been documented (Philippe et al. 1996). As shown in Figure 10b, f, this inversion caused basement uplift and late deformation/refolding of the earlier thin-skinned cover nappes. In the northern Jura, seismic data demonstrate that the faults underlying some of the northernmost folds are high-angle reverse faults that extend down into the basement, supporting that thick-skinned tectonics prevailed here (Rotstein \& Schaming, 2004). Ustaszewski \& Schmid (2006, 2007) later provided additional seismic evidence for basement-involved shortening. Figure 10e shows an E-W-trending, N-dipping highangle basement fault of late Palaeozoic origin reactivated in compression that truncates the syn-rift fill and almost reaches the surface. Because this fault clearly cuts through the décollement, it most probably formed during a post 4-3 Ma thick-skinned tectonic stage. Geomorphological evidence from the southernmost Rhinegraben revealed the spatial coincidence between gentle anticlines in the base of the Pliocene fluvial Sundgau gravels and transpressively/compressively reactivated basement faults (Giamboni et al. 2004). These observations altogether confirm that in the Jura thinskinned tectonics was followed by thick-skinned tectonics. A crustal décollement presumably rooting at the upper-lower crust transition and extending beneath the Molasse Basin and the Internal Jura is required to accommodate displacements and thickskinned shortening related to inversion of the PermoCarboniferous basins (Pfiffner, Erard \& Stauble, 1997; Lacombe \& Mouthereau, 2002). The ongoing character of thick-skinned tectonics in the Jura is evidenced by 


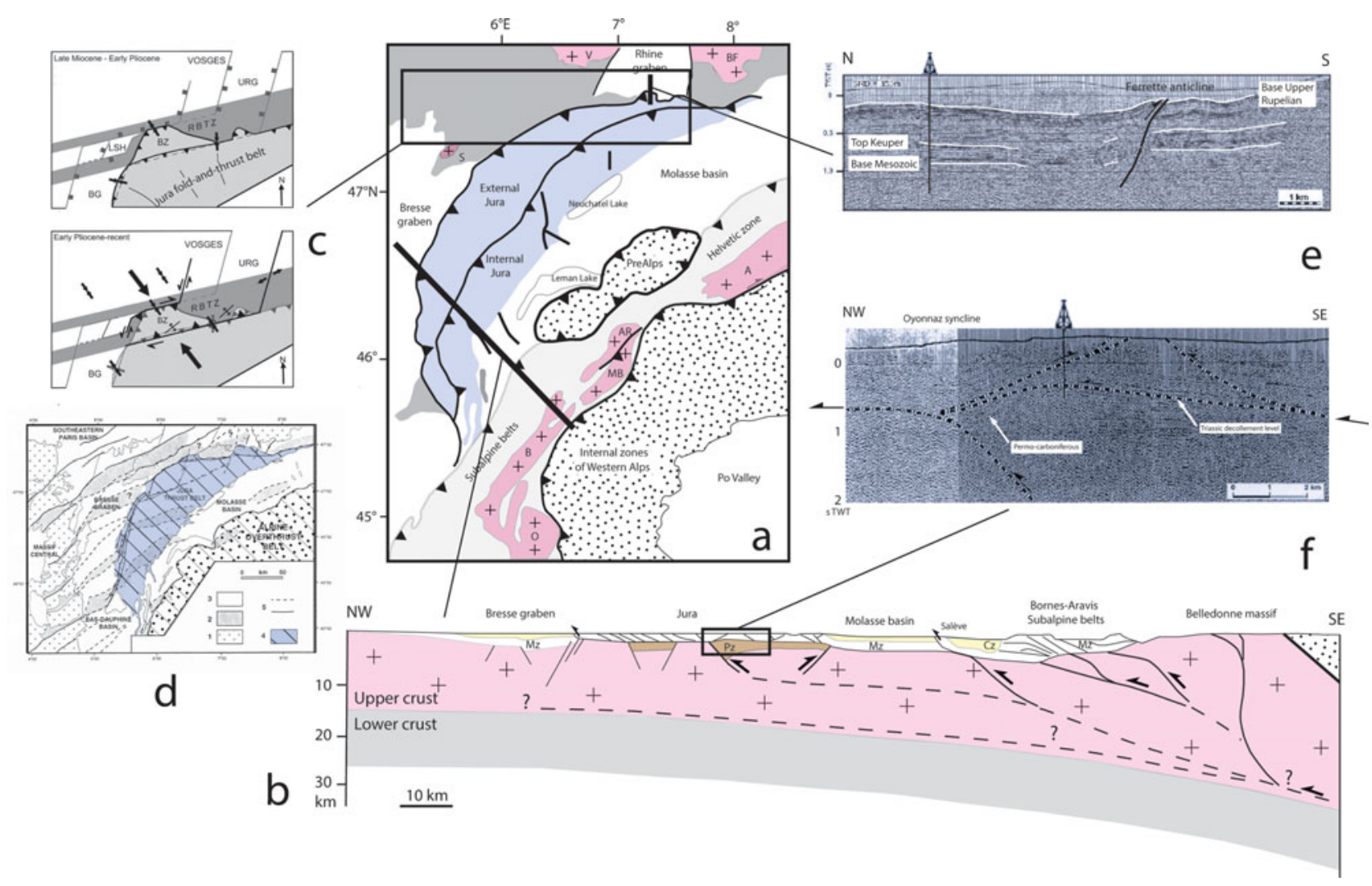

Figure 10. (Colour online) (a) Simplified structural map of the NW Alpine foreland. V - Vosges; BF - Black Forest; AR - Aiguilles Rouges; MB - Mont Blanc; B - Belledonne; O-Oisans. (b) Crustal-scale cross sections from the Bresse graben to the Belledonne massif emphasizing inversion of inherited Palaeozoic basin beneath the thin-skinned Jura FTB, basement thrusting and likely occurrence of a deep crustal décollement rooting at the brittle-ductile transition. $\mathrm{Pz}, \mathrm{Mz}$ and $\mathrm{Cz}-$ Palaeozoic, Mesozoic and Cenozoic. (c) Two-stage tectonic evolution the northwestern Jura front. Late Miocene to early Pliocene thin-skinned deformation dominated in the Besançon Zone (BZ), followed by thick-skinned deformation involving both Mesozoic cover and Palaeozoic basement in the Avant-Monts Zone. This thick-skinned deformation is associated with compressional to transpressional reactivation of pre-existing normal faults of Palaeogene to Palaeozoic age of the intracontinental Rhine-Bresse Transfer Zone (RBTZ) and the underlying late Palaeozoic Burgundy Trough (modified after Madritsch, Schmid \& Fabbri, 2008). BG - Bresse graben; LSH - La Serre Horst; URG - Upper Rhinegraben. (d) Distribution of inherited Permo-Carboniferous basins beneath the Jura and the Alpine foreland (modified after Truffert et al. 1990). 1 - Palaeozoic basement. 2 - Permo-Carboniferous basins. 3 - Meso-Cenozoic cover of the Alpine foreland. 4 - Jura FTB. 5 - Faults bounding Permo-Carboniferous basins (documented = solid lines $/$ inferred $=$ dashed lines). (e) Seismic evidence for the compressional reactivation of an E-W-trending, N-dipping high-angle late Palaeozoic basement fault in northern Jura. This fault clearly cuts through the décollement and probably formed during the thick-skinned post-4-3 Ma tectonic stage. (f) Seismic evidence of inversion of a Permo-Carboniferous graben underneath the Jura and post-dating thin-skinned folding and thrusting (modified after Philippe et al. 1996).

seismological data as well as levelling data (Meyer et al. 1994; Mosar, 1999; Lacombe \& Mouthereau, 2002). Seismic activity testifies that the whole crust is actively deforming in the entire internal Jura-Molasse basin domain and is not limited to the Mesozoic cover. The close spatial relationships between the occurrence of seismicity, basement thrusting and the presence of inverted Permo-Carboniferous basins beneath the Mesozoic cover suggest triggering of thick-skinned tectonics by pre-existing inherited extensional structures (Lacombe $\&$ Mouthereau, 2002) under the Plio-Pleistocene and modern Alpine stress fields.

Madritsch, Schmid \& Fabbri (2008) provided evidence for two contrasting styles of Neogene to recent contraction along the northwestern Jura front (Fig. 10c). Late Miocene to early Pliocene thin-skinned deformation dominated in the Besançon Zone. Palaeostress directions reveal a consistently fanning pattern.
Thick-skinned deformation, involving both Mesozoic cover and Palaeozoic basement, is documented in the Avant-Monts Zone and has taken place under a NWSE compression. This deformation is associated with compressional to transpressional reactivation of preexisting normal faults of Palaeogene to Palaeozoic age of the intracontinental Rhine-Bresse Transfer Zone and the underlying late Palaeozoic Burgundy Trough. The complex structural setting at the northwestern Jura front (Fig. 10c) thus results from spatial interferences between the two different styles of deformation. Deepseated seismogenic thick-skinned tectonics and, local, presumably largely aseismic, still active shallow décollement tectonics may interact in space and time from early Pliocene times (4.2 Ma) to the present (Madritsch, Schmid \& Fabbri, 2008).

To summarize, the tectonic evolution of the Molasse Basin - Jura Mountains system comprises both 
thin-skinned tectonics along a basal décollement within the Triassic evaporites (e.g. Philippe et al. 1996) and basement shortening above a deeper décollement (Pfiffner, Erard \& Stauble, 1997), which accounts for the inversion of underlying Permo-Carboniferous grabens (Fig. 10d) and accommodates stacking of basement thrust units beneath the ECMs (Lacombe \& Mouthereau, 2002; Bellahsen et al. 2014). Deep-seated thrusting occurred (during and) after the cover detached along the basal Triassic décollement, causing basement uplift and late deformation of the thin-skinned nappes. The most plausible explanation so far for the transition from thin-skinned tectonics to basement-rooted deformation is ongoing tectonic underplating in the northwestern Alpine foreland with the Alpine wedge evolving to reach a new state of equilibrium (Mosar, 1999).

\section{Basement uplifts in retro-forelands: Laramide province and Sierras Pampeanas}

Although observed at many places in the world, foreland basement-cored arches are still poorly understood owing to the fact that they often occur distant from plate boundaries (e.g. Yeck et al. 2014). These arches comprise many prominent mountain ranges including the Tian Shan, the Sierras Pampeanas of Argentina and much of the US Rocky Mountains.

The Andean system displays distinctive along- and across-strike changes in structural style that correlate with changes in both crustal architecture and plate dynamics (Ramos, Cristallini \& Perez, 2002; Ramos et al. 2004). To this respect, the Precordillera and Sierras Pampeanas in western Argentina show an outstanding analogy with the Sevier and Laramide belts, respectively (Jordan \& Allmendinger, 1986; Fielding \& Jordan, 1988; Fig. 11a), although some differences exist (Yonkee \& Weil, 2015).

\section{6.a. Laramide uplifts}

The Laramide belt consists of the deformed and disrupted foreland of the former Sevier orogeny and developed at the expense of North American cratonic lithosphere (Yonkee \& Weil, 2015). The belt exhibits a network of anastomosing thick-skinned, basementcored anticlines and uplifts (the so-called 'arches') separated by broad basins, which developed more than $1000 \mathrm{~km}$ inboard from the plate margin, spanning a region from southern Montana to New Mexico (Erslev, 1993; Fig. 11a). The Laramide arches are bounded by moderate-dipping reverse faults with offsets of $\sim 10$ $30 \mathrm{~km}$ and continue upwards into folds in the sedimentary cover (Brown, 1988; Stone, 1993; Fig. 11c). Major reverse faults are imaged geophysically to midcrustal ( 20 to $30 \mathrm{~km}$ ) depths (Smithson et al. 1979; Lynn, Quam \& Thompson, 1983) and likely flatten in the lower crust or within a mid-crustal weak zone (Fig. 11c). The various local trends of the arches, compared to the overall NW-SE grain of the Laramide belt, has been tentatively explained by the reactivation of pre-existing crustal weaknesses with different orientations, including metamorphic foliations, shear zones, dykes and Proterozoic normal faults, which partly influenced localization of deformation (Mitra \& Frost, 1981; Marshak, Karlstrom \& Timmons, 2000; Stone, 2002; Neely \& Erslev, 2009).

Shortening accommodated by reverse faults and folds is $\sim 50 \mathrm{~km}$ across the Wyoming foreland (Stone, 1993; Fig. 11c). Low-temperature thermochronometry (e.g. Fan \& Carrapa, 2014) as well as thickness variations, progressive unconformities and clastic content of the Maastrichtian to lower Eocene synorogenic strata indicate that Laramide deformation lasted from 70 to $50 \mathrm{Ma}$, temporally overlapping with late Sevier deformation (e.g. Dickinson et al. 1988; see synthesis in Yonkee \& Weil, 2015). However, within the Laramide belt, deformation did not propagate regularly in a classical 'in sequence', forelandward (eastward) fashion; for instance, Crowley et al. (2002) documented an earlier uplift of the Bighorn Mountain arch located east of the Bighorn basin. Thus, depending on the more or less favourable orientation of pre-existing crustal weaknesses and anisotropies, individual arches may have developed in a rather complex sequence in space and time.

Laramide deformation roughly coincided spatially and temporally with Late Cretaceous to Palaeogene development of a flat-slab subduction segment, interpreted to have developed during subduction of the conjugate to the Shatsky Rise, a broad oceanic plateau that formed along the ancestral Pacific ridge (e.g. Livaccari, Burke \& Şengör, 1981). Flat-slab subduction is known to be favoured by rapid convergence, trenchward absolute motion of the upper plate and increased buoyancy from thicker subducted crust (Gutscher et al. 2000; van Hunen, van der Berg \& Vlarr, 2002; Espurt et al. 2008). These factors likely contributed to the ancient Laramide flat slab of the North American Cordillera (Saleeby, 2003; Liu et al. 2010), and currently contribute to the Andean $27-33^{\circ} \mathrm{S}$ flat-slab segment where the thick-skinned Sierras Pampeanas are actively uplifting (Fig. 11a).

Dynamic processes that could have enhanced stress transfer into the upper plate and produced thick-skinned crustal deformation are still largely debated (Yonkee \& Weil, 2015). Rather than being transmitted tangentially through continental basement rocks from the active plate boundary along the continental margin to the west, Laramide compressive stresses are considered in more recent views to arise from shear/basal traction between the continental lithosphere and the underlying flat slab of subducted oceanic lithosphere, from increased coupling along a cratonic lithosphere root, from hydrodynamic forces related to forced mantle convection, and/or from return flow where the slab steepened (Dickinson \& Snyder, 1978; Bird, 1984, 1988; Livaccari, 1991; Tikoff \& Maxson, 2001; English, Johnston \& Wang, 2003; O'Driscoll, Humphries \& Saucier, 2009; Jones et al. 2011). Such specific boundary 


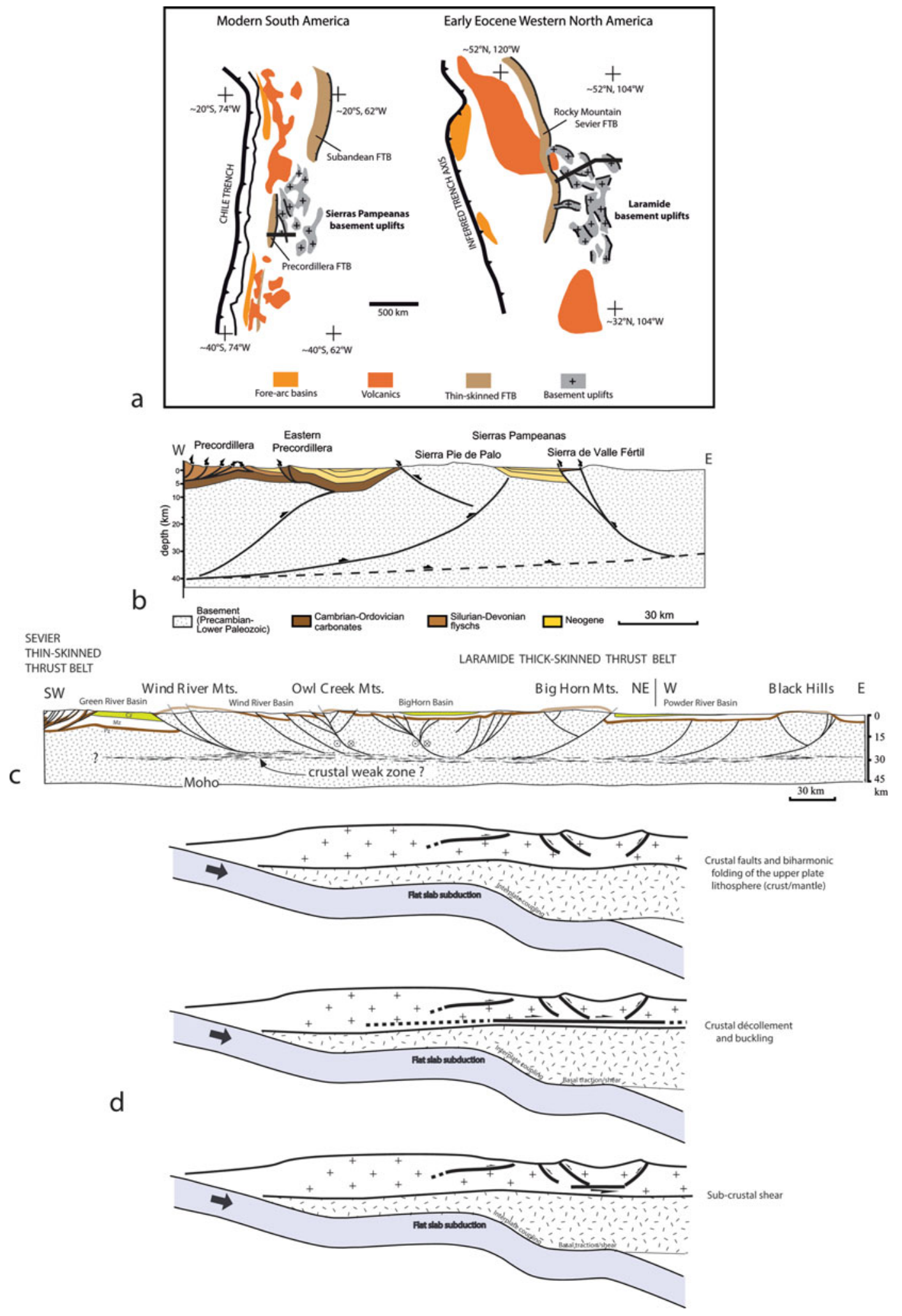

Figure 11. (Colour online) (a) Modern geodynamic setting of the Sierras Pampeanas of Argentina compared to the early Eocene geodynamic setting of the Laramide uplifts in the foreland of the Rockies (modified after Jordan \& Allmendinger, 1986). (b) Structural section across the Precordillera and the Sierras Pampeanas (location shown by heavy line in a) (Bellahsen et al. 2016, this issue). (c) Structural section across the easternmost Sevier thin-skinned FTB and the Laramide basement uplifts (location shown by heavy line in a) (modified after Stone, 1993; Marshak, Karlstrom \& Timmons, 2000). (d) Possible models of accommodation of Laramide uplifts at the crustal/lithospheric scale, which could also apply to the Sierras Pampeanas. 
conditions enhancing interplate coupling (see Section 9), possibly associated with a particular rheological behaviour of the upper plate tectonized lithosphere either inherited or linked to the geodynamic flat subduction setting itself (cooling, hydration) (see Sections 8 and 9), caused diffuse intraplate shortening and related basement uplifts.

Different tectonic models have been proposed that predict kinematics of shortening in the upper plate, leading to the rise of foreland arches (Erslev, 2005); these include buckling of the upper-plate lithosphere (Tikoff \& Maxson, 2001), buckling and folding of the upper crust driven by mid-crustal décollement (Erslev \& Rogers, 1993; Yeck et al. 2014) or sub-crustal shear (Fig. 11d). Buckling and fault-propagation folding in the upper crust accommodated by pure shear thickening in the lower crust has also been proposed (Egan \& Urquhart, 1993). These mechanisms are not mutually exclusive: the most recent geophysical investigations of the crustal structure of the Laramide arches (Bighorn Arch Seismic Experiment) (Worthington et al. 2016) suggest that Laramide shortening of the Bighorn Arch may have been controlled by one, or a combination, of the following: (1) nucleation of deformation on a preexisting weakness associated with a Precambrian tectonic boundary at the eastern edge of the Bighorn Arch; (2) localization of deformation in an area with relatively weak lower crust compared to surrounding regions; (3) accommodation of deformation by a crustal décollement focused into the upper crust by a regional Moho high, possibly enhanced by a small amount of lithospheric buckling, which allowed the emergent thrusting of the Bighorn master thrust.

\section{6.b. Sierras Pampeanas}

The Sierras Pampeanas ranges are located east of the Andes and extend between latitudes $27^{\circ} \mathrm{S}$ and $33^{\circ} \mathrm{S}$ and longitudes $64^{\circ} \mathrm{W}$ and $68^{\circ} \mathrm{W}$ (Fig. 11a) in Argentina. There, the Andean foreland displays a wide retroarc belt. Two compressional, $\sim \mathrm{N}-\mathrm{S}$-striking, oppositeverging structural domains are facing: (1) the $\sim 40 \mathrm{~km}$ wide, E-verging, thin-skinned Precordillera FTB made of Palaeozoic rocks and extending just to the east of the main high Andes, and (2) the $\sim 350 \mathrm{~km}$ wide, thick-skinned Sierras Pampeanas domain with mostly W-verging basement uplifts made of Precambrian and lower Palaeozoic metamorphic rocks. The E-verging thin-skinned thrusts initiated by early to middle Miocene times, earlier than the Pampean basement uplifts, which started between late Miocene times in the north and Pliocene-Quaternary times in the south. Accordingly, these basements uplifts are located within the distal part of the Miocene foreland basin where they occurred as out-of-sequence faulted blocks, giving birth to a broken foreland (e.g. Allmendinger et al . 1983; Strecker et al. 1989, 2012; Hain et al. 2011) (see Section 10). These block uplifts are controlled by the reactivation of inherited crustal weaknesses, like Proterozoic or Palaeozoic(?) sutures and late Palaeo- zoic or Cretaceous normal faults (e.g. Kley \& Monaldi, 2002; Ramos, Cristallini \& Perez, 2002), which explain their variable lengths from several tens to several hundreds of kilometres.

The Sierras Pampeanas basement block uplifts developed where the Nazca slab, which is subducting eastwards below the western edge of the South American plate, flattens below the Andes at a depth of $\sim 100 \mathrm{~km}$ (e.g. Jordan et al. 1983; Smalley \& Isacks, 1987; Cahill \& Isacks, 1992; Anderson et al. 2007). Initial shallowing of the subduction zone was possibly underway by $\sim 20-18 \mathrm{Ma}$ and lasted until $10 \mathrm{Ma}$, causing initiation of thrusting and basin formation in the Precordillera; the main shallowing phase occurred at $\sim 10$ $5 \mathrm{Ma}$, with continued thrusting in the Precordillera, and major uplift of the Sierras Pampeanas beginning at $\sim 6 \mathrm{Ma}$ (Kay \& Abbruzzi, 1996). This flat-slab geometry appears to result from the subduction of the Juan Fernandez aseismic ridge that initiated between $14 \mathrm{Ma}$ and $11 \mathrm{Ma}$ and increased the buoyancy of the Nazca plate (Pilger, 1981; Gutscher et al. 2000).

The section of Figure $11 \mathrm{~b}$ cuts across part of a $\sim 400 \mathrm{~km}$ wide domain of the South-Central Sierras Pampeanas. There, the depth of the continental Moho varies from $66 \mathrm{~km}$ below the Central Precordillera (Ammirati et al. 2013) to $52 \mathrm{~km}$ below the Sierra Pie de Palo (Calkins et al. 2006), while it is only $38 \mathrm{~km}$ and $35 \mathrm{~km}$ below the western and eastern parts of the Sierra de Cordoba, respectively (Perarnau et al. 2012). Crustal seismicity (Regnier et al. 1992; Smalley et al. 1993) is seemingly limited at depth by a $\sim 34 \mathrm{~km}$ deep seismic discontinuity (noticeably, a depth similar to the $32 \mathrm{~km}$ flattening depth of the Wind River thrust (Lynn, Quam \& Thompson, 1983) and more generally to the depth of the weak crustal zone where Laramide crustal faults presumably root in the Laramide province (Marshak, Karlstrom \& Timmons, 2000; Fig. 11c)), while a shallower one is observed at a depth of $\sim 18 \mathrm{~km}$ (Calkins et al. 2006; Alvarado, Beck \& Zandt, 2007, Ammirati, Alvarado \& Beck, 2015). This seismic discontinuity near the base of the crustal seismicity could correspond to the main Andean décollement that likely allowed Andean shortening to propagate eastwards to the Sierra Pampeanas. This deep crustal seismicity (e.g. Smalley \& Isacks, 1990) is consistent with a low thermal gradient, in agreement with the flat-slab subduction setting, for which thermal modelling indicates a value of $\sim 10^{\circ} \mathrm{km}^{-1}$ caused by the lack of asthenospheric wedge (Gutscher et al. 2000) to be compared to values of around $\sim 30^{\circ} \mathrm{km}^{-1}$ above steeper Andean subduction segments, and in agreement with the low thermal gradients reported in the Neogene basins (Collo et al. 2011; Davila \& Carter, 2013).

An example of basement uplift is provided by the Pie de Palo range (Fig. 11b). It is an actively growing basement anticline bounded by major faults and associated with a high level of crustal seismicity (Régnier et al. 1992; Smalley et al. 1993; Ramos, Cristallini \& Perez, 2002; Siame et al. 2002, 2015; Siame, Bellier \& Sébrier, 2006). The Tulum fault system (Zambrano \& 
Suvires, 2008) limits the western edge of the Pampean Precambrian outcrops from the Palaeozoic outcrops of the Eastern Precordillera (Ramos, Cristallini \& Perez, 2002) and corresponds further south to the western front of the active Pampean thrust system (Verges et al. 2007; Cisneros, Costa \& Gardini, 2010). The structure controlling the eastern border of the Pie de Palo range is considered either as dipping east (Langer \& Bollinger, 1988; Costa et al. 2000; Ramos, Cristallini \& Perez, 2002) or west (Kadinsky-Cade, Reilinger \& Isacks, 1985; Reilinger \& Kadinsky-Cade, 1985; Fig. 11b). The significance of the Pie de Palo anticline is still debated, being interpreted either as a W-verging faultbend fold or an E-verging fault-propagation fold.

Summarizing, the striking similarity between the Sierras Pampeanas of Argentina and the Laramide uplifts strongly suggests that flat-slab subduction at an advancing subduction zone, possibly enhanced by increased coupling along a cratonic lithosphere root, appears to be a favourable setting to develop a wide retro-arc compressional province, leading to diffuse intraplate basement shortening well inboard the plate boundary. This setting is also associated with a low temperature gradient within the upper plate. This similarity suggests that tectonic models proposed to explain stress transfer and shortening in the upper plate in the Laramide belt, such as lithospheric buckling or fault-propagation folding of the upper crust driven by mid-crustal décollement, may also apply to the Sierras Pampeanas. The overall oceanward (westward) vergence of both the Laramide and Sierras Pampeanas uplifts, opposite to the E-verging, thin-skinned Sevier and Precordillera FTBs, respectively, may additionally suggest that shearing at the base of the upper plate crust/lithosphere under the far foreland in response to flat-slab subduction may have been significant.

\section{Styles, kinematics and mechanics of basement-cored folding}

In basement-cored anticlines, the overlying sedimentary cover is folded. If either the underlying basementcover unconformity or the basement cannot be directly or entirely observed, the first point to address is whether basement rocks are really folded or not. If yes, one must examine how to fold the crystalline basement rocks usually considered as rigid and isotropic to a first order. If not, the question is to understand how the cover may fold above an unfolded basement. Examination of basement uplifts and related cover deformation in the Laramide belt, Sierras Pampeanas and western Alps provides some insights into these questions.

\section{7.a. Basement-cored anticlines and basement uplifts: Laramide province and Sierras Pampeanas}

In the Laramide province of the central Rocky Mountains, there is an overall agreement that the formation of basement thrusts within the Precambrian basement is a prerequisite for the development of thick-skinned folds within the overlying sedimentary cover (Stone, 1993; Fig. 12a, b). The variation in map view and in 3D geometries of individual structures, as well as their mutual spatial and angular relationships, is strongly suggestive of the influence of pre-existing basement discontinuities at depth (Paul \& Mitra, 2012). The pattern of basement uplifts are therefore controlled by reactivated faults at depth (that in most places remain blind, either covered by Cenozoic sediments, or expressed at the surface as a monoclinal fault-propagation fold of Palaeozoic and Mesozoic strata), with only neoformed offshoots of those faults being most of the time exposed at the surface (Bump, 2003).

Thrusts are nearly planar within the basement, then propagate and steepen upwards, usually accompanied by fold backlimb rotation (Stone, 1993). The overlying Phanerozoic sedimentary cover is uplifted and stretched over rising hangingwall basement blocks, and ultimately offset by the propagating thrusts along the forelimbs of anticlines.

One of the important factors about fault-related folds in basement rocks is whether the basement-cover contact on the steep forelimb of the fold is a fault contact or a rotated unconformity. This implies a different behaviour below the cover (Fig. 12a1, a2) (Schmidt, Genovese \& Chase, 1993). In some folds, the forelimb basement-cover interface is a fault (Fig. 12a1). These folds developed when there is a lack of significant foliation or weaknesses in the basement, which is therefore basically isotropic at the time of shortening (Schmidt, Genovese \& Chase, 1993). In this case, all happens as if a relatively competent basement block was indenting a relatively incompetent cover, resulting in no significant basement deformation. In contrast, in other folds, the forelimb basement-cover interface is a rotated unconformity (Fig. 12a2). These folds are seemingly associated with a relatively deformable basement block forced against a competent cover. Basement can be deformed through slip on sets of closely spaced fractures, through flexural slip on pre-existing foliation oriented sub-parallel to bedding, through axial surface-parallel slip on foliation favourably oriented for simple shearing parallel to the master fault or through pervasive cataclasis (Schmidt, Genovese \& Chase, 1993; Chase, Schmidt \& Genovese, 1993).

In the case where metamorphic foliation in the basement rocks is parallel (or nearly parallel) to bedding of the cover rocks, folding of the entire package may occur by flexural slip, giving rise to a true basement fold (Schmidt, Genovese \& Chase, 1993). Passive folding of the basement may also occur by combined thrust and back-thrust folding assisted by fracturing (Garcia \& Davis, 2004; Fig. 12e). Alternatively, the curved attitude of the basement-cover interface may only mimic true basement folding. Several mechanisms may account for such folding of cover rocks without folding of basement rocks, such as basement faulted by a single fault or by several faults (e.g. Fig. 12b), or by fault zones containing wedges of cataclastic material (e.g. Erslev, 1986; Spang \& Evans, 1988; Stone, 1993; 


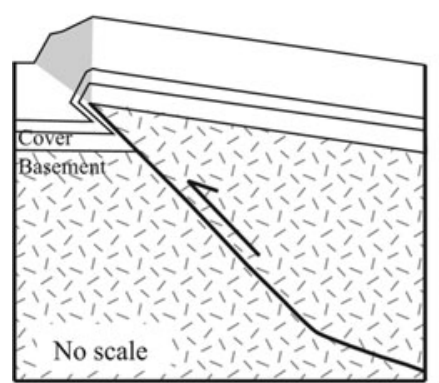

a1

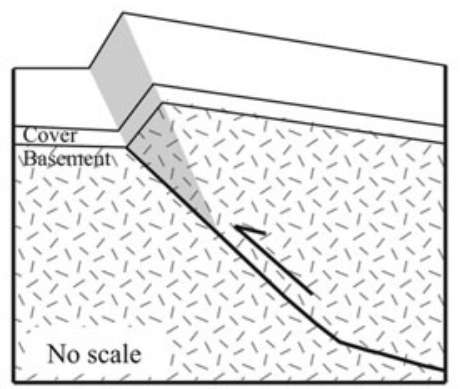

a2

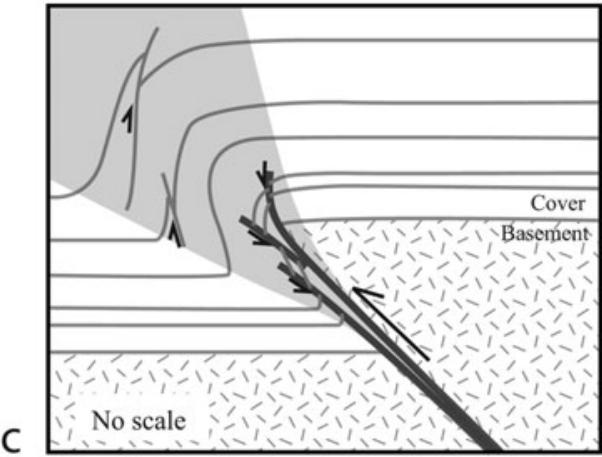

$\mathrm{C}$

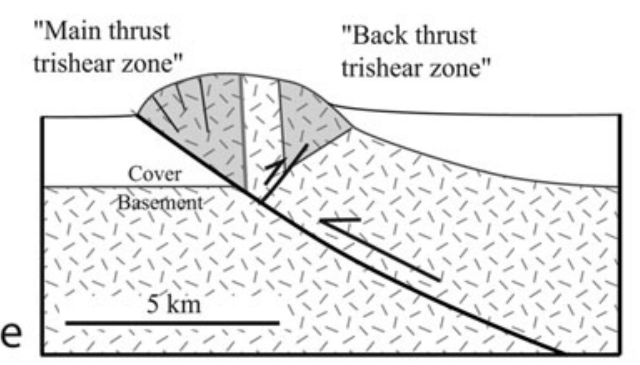

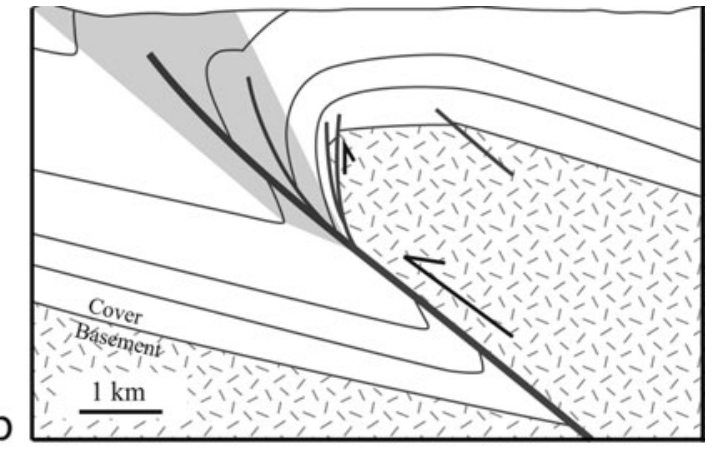

Fig.13a,b

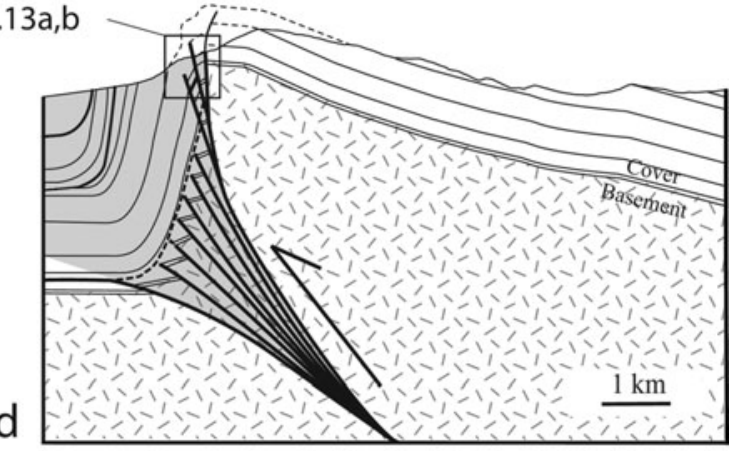

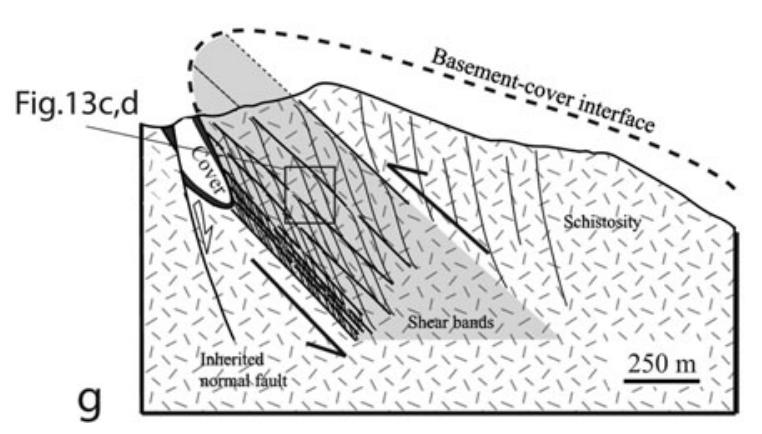

Figure 12. Basement-cored folding. The shaded area denotes the domain where basement and/or cover are physically damaged and strained as a result of the accommodation of slip along the master thrust. (a) Folds where the forelimb basement-cover interface is a fault (a1) compared to folds where the forelimb basement-cover interface is a rotated unconformity (a2) (modified after Schmidt, Genovese \& Chase, 1993). (b) Section across the Maverick Spring anticline (Laramide belt) (modified after Stone, 1993). (c) Trishear model (Erslev, 1991). (d) Interpretation of the Rattlesnake anticline (Laramide belt), involving distributed deformation along splay faults at the tip of the basement fault and at the top of the basement (Beaudoin et al. 2012). (e) Sierra de Hualfin anticline (Sierras Pampeanas): basement folding is accommodated by both a main thrust trishear zone and a subordinate back-thrust trishear zone (modified after Garcia \& Davis, 2004). (f) Sierra Pie de Palo anticline (Sierras Pampeanas): basement shortening is accommodated by reverse faults localized along inherited foliation planes in the basement (Bellahsen et al. 2016, this issue). (g) Oisans ECM (western Alps): 'folding' of the basement-cover interface is spatially associated with low-angle basement shear zones distributed over a large thickness (modified after Bellahsen et al. 2012).

Narr, 1993; Schmidt, Genovese \& Chase, 1993; Narr \& Suppe, 1994).

The mechanical response of the basement rocks as well as the overall fold geometry is highly dependent on the temperature and confining pressure during deformation, the nature and orientation of the pre-deformation fabric of the basement rocks and the competence of the cover rocks and the degree to which folded strata are decoupled or welded to the basement blocks. In the Laramide arches, Schmidt, Genovese \& Chase (1993) estimated the depth at the upper basement rock surface during folding at about 2.5 to $5 \mathrm{~km}$, hence a lithostatic 
pressure in the range $70-135 \mathrm{MPa}$, and a temperature during deformation in the range $70-120^{\circ} \mathrm{C}$, which suggests a brittle (or semi-brittle) mechanical behaviour of the basement rocks.

The propagation of the tip of an advancing basement fault creates, beyond the tip, a physical ground preparation of the medium that not only may accommodate further tip advance but also folding of the material through which the tip may propagate (Bump, 2003; Garcia \& Davis, 2004). In the trishear example (Erslev, 1991; Fig. 12c), the trishear angle, combined with slip magnitude, influences the size of the basement-cover folded interface. The damage in the trishear zone, in combination with pre-deformational anisotropies, may even give to granite a kind of macroductility (Garcia \& Davis, 2004). Another key factor controlling folding of the basement is the initial position of the tip of the thrust fault that caused basement uplift. Basement-cored uplifts that form as a result of a fault that propagates over a short distance from the basement-cover interface or from the interface (i.e. reactivation of a previous fault or fracture) show minor deformation of the basement and considerable deformation of the overlying sedimentary rocks (Fig. 12c; Garcia \& Davis, 2004). However, if the fault tip is initially located deep in the basement and does not propagate to the basement-cover interface but remains in the basement while slip is fed into the fault, then basement rocks above the fault tip must deform in order to accommodate slip (Bump, 2003). To this respect, Figure 12d shows the interpretation of the Rattlesnake Mountain anticline by Beaudoin et al. (2012). This interpretation involves distributed deformation along splay faults at the tip of the basement fault and at the top of the basement (Beaudoin et al. 2012). In this model, the tip of the basement fault is not located just at the basement-cover interface but deeper in the basement, which implies that the triangle zone where distributed deformation/damage occurs (splays faults, with cataclasis or intensively fractured rocks) is located within the basement. This particular behaviour could be tentatively related to high fluid pressure and related hydrofracturing leading to distributed brittle deformation. The behaviour of the basement that crops out along the Shoshone river (Fig. 13a) is clearly brittle, with high-angle reverse faults being parallel to (likely preexisting) major fractures in the basement (Fig. 13b).

On the basis of their study of the Sierra de Hualfin in Argentina, Garcia \& Davis (2004) emphasized that the most important condition for the crystalline basement to fold is its rheology during deformation (e.g. Chase, Schmidt \& Genovese, 1993). The deformability of the basement may be achieved by pervasive faults and fractures that pre-dated, and/or formed during, folding. Because the basement is always pervaded with fractures and possible additional metamorphic or dyke fabrics, it no longer behaves as a rigid and isotropic medium and may fold.

In the Sierra de Hualfin, folding is accommodated by both a main thrust trishear zone and a subordinate back-thrust trishear zone (Fig. 12e; Garcia \& Davis,
2004). At shallow basement levels, the smooth folded shape of the basement unconformity is achieved through movements on joints, minor faults and 'brittle' foliation. Faulting along spaced reactivated joints imparts an overall fold shape to the basement. Deeper in the basement, the combination of joints and faults allows the deformation and distortion of the basement rocks into a fold shape. Garcia \& Davis (2004) challenged models of basement-cored uplifts that assume that the fault tip is located at the basement-cover interface, and stressed that some basement-cored anticlines can be attributed to basement distortion taking place in advance of a propagating fault tip below the basementcover unconformity.

In the Sierra Pie de Palo, basement shortening occurred at very low depth, i.e. the basement top was less than $1 \mathrm{~km}$ deep, and was accommodated on several reverse faults that deform the Tertiary continental beds (Bellahsen et al. 2016, this issue). These faults are not as large and as deep as previously proposed but are rather small and short faults that accommodate a largescale 'folding'/buckling of the crust. The proposed 'folding' mechanism thus involves reverse faults localized along inherited foliation planes in the basement. There, fine-grained foliation planes localized foliationparallel shearing, which evolved as small-scale asymmetric folds and ultimately into cataclastic zones that constitute the present-day faults (Fig. 12f). Thus, it appears that the shortening has been achieved by reverse faults distributed in the crust that reactivated preexisting basement anisotropies and weaknesses (inherited foliation planes) and accommodated a large-scale antiform above an E-verging blind thrust (Fig. 11b) (Bellahsen et al. 2016, this issue).

\section{7.b. 'Basement folds' in the External Crystalline Massifs of the western Alps}

In the ECMs, crustal thickening gave rise to so-called 'basement folds' (Ford, 1996; Gidon, 1999; Dumont et al. 2008). The northern Grandes Rousses crosssection (Fig. 9c3) displays two main 'basement antiforms', the eastern one being shown in Figure 12g. The two basement antiforms are separated by a tight syncline of Liassic rocks that is bounded to the west by a steep inherited Jurassic normal fault that offsets the Triassic layers and brings the Jurassic rocks directly over the basement. Because deformation in the central ECMs (Belledonne, Oisans) occurred at a maximum temperature of $330{ }^{\circ} \mathrm{C}$ (Bellanger et al. 2014) and under a tectonic burial of presumably about $10 \mathrm{~km}$, these massifs provide the opportunity to address the question of basement folding at crustal depths greater than in the Laramide province and the Sierras Pampeanas.

Basement folding has been inferred from the curved attitude of the cover-basement interface as reflected by the Triassic layers that remained welded to the basement. However, the related deformation in the basement has only been recently deciphered. Bellahsen et al. (2012) and Bellanger et al. (2014) described shear zones associated with a sigmoid-shaped Alpine 


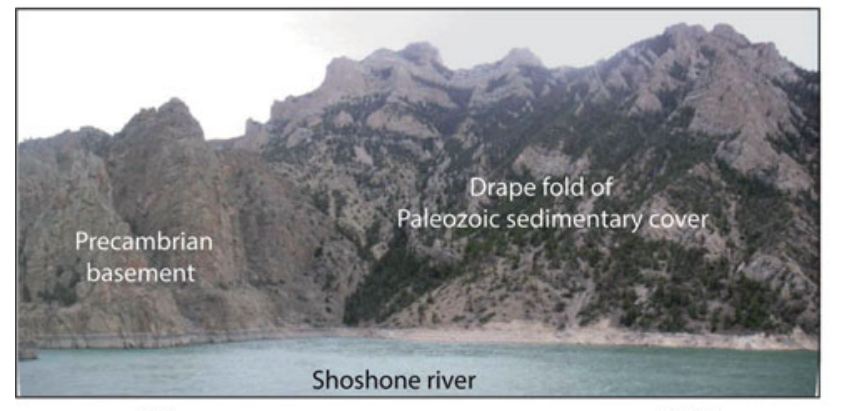

a

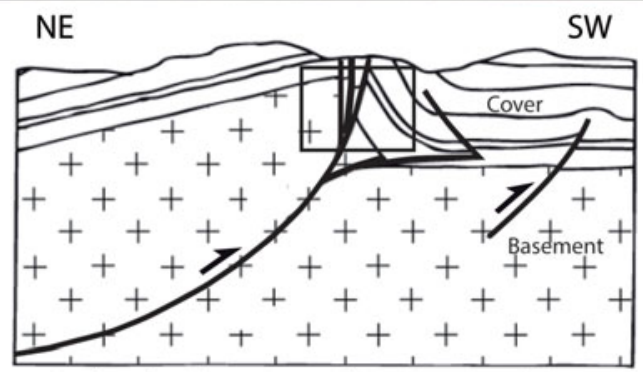

Rattlesnake Mountain anticline, Wyoming, USA

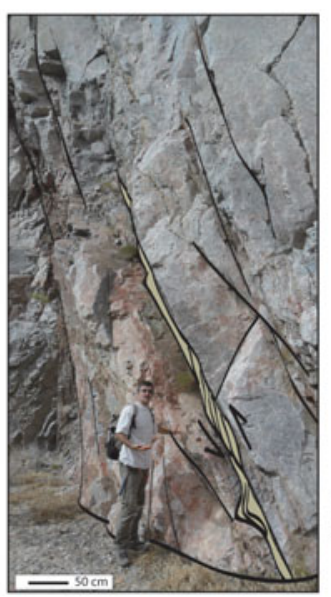

\section{b} high-angle reverse fault with a shaly gouge, within the basement.

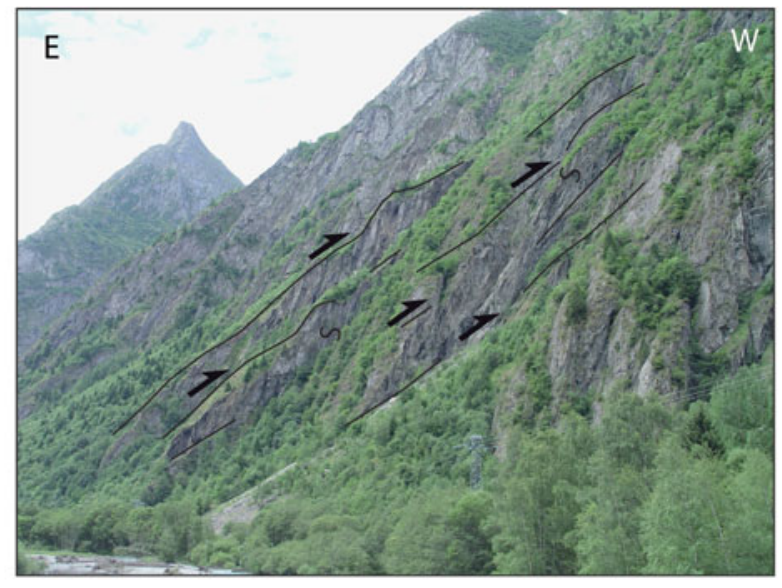

C Plan du Lac basement shear zones (Oisans Massif, Western Alps)

d

Mylonitic deformation associated with

basement shear zones in the Oisans Massif (Western Alps)

Rattlesnale Mountain anticline :

in the Precambrian basement rocks.

The fault is parallel to major fractures
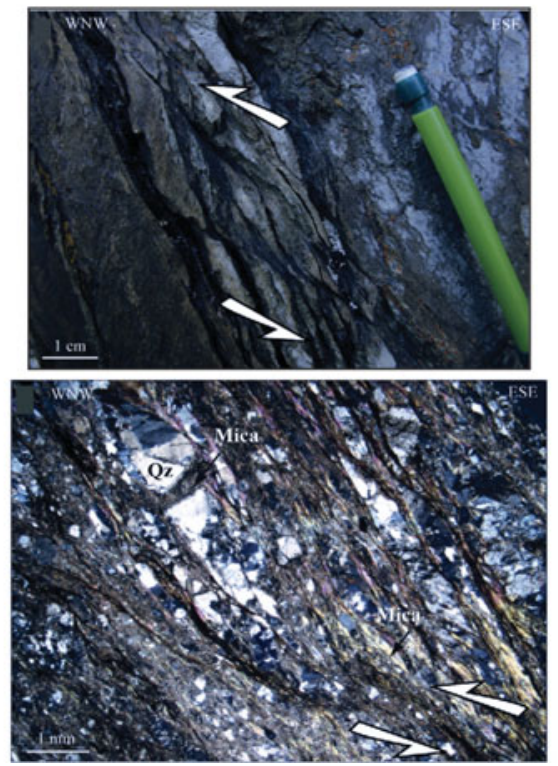

Figure 13. (Colour online) Field examples of basement-involved shortening. (a) Photograph and schematic interpretative cross-section of the Rattlesnake Mountain anticline. (b) Field evidence of the brittle behaviour of the basement rocks that crop out along the Shoshone river in the Rattlesnake Mountain anticline, showing high-angle reverse faults parallel to major fractures within the basement (modified after Beaudoin et al. 2012). (c) Field evidence of W-verging reverse shear zones within the basement of the Oisans ECM. Note the sigmoidal shape of the Alpine schistosity (S) within the shear zones. (d) Evidence for mylonitic deformation associated with basement shear zones in the Oisans Massif (western Alps) (modified after Bellahsen et al. 2012). Qz - quartz.

schistosity that support reverse, top-to-the-W shear kinematics (Figs 12g, 13c). Close to the cover (Liassic) syncline, shear zones and schistosity are nearly parallel. Such maximum shearing of the basement is observed where the Triassic strata are steeply dipping and locally overturned.

The shear zones contain a large amount of chlorite and white micas suggesting that they developed under greenschist-facies conditions. Quartz clasts are mainly fractured but the overall mylonitic deformation is due to the large amount of white micas that grew coevally with quartz deformation (Fig. 13d), reflecting deformation in the brittle-ductile regime.

Dumont et al. (2008) suggested that the basement thrusts in the Oisans-Grandes Rousses massifs result from the reactivation of the steep Variscan foliation, which is ruled out by the shallow dip of the shear zones.
Alternatively, Butler, Tavarnelli \& Grasso (2006) suggested that basement deformation might be due to the buckling of the upper crust characterized by lithology contrasts (especially the basement-cover interface). If the initiation of the deformation by buckling cannot be ruled out, shortening is most probably not only due to this mechanism as stressed by Bellahsen et al. (2012): the spacing of the deformed zones (a few hundreds of metres to a few kilometres) is too small to be controlled by buckling and the preferential vergence of the shear zones does not support a buckling mechanism that would have implied a rather pure shear deformation. Thus, 'folding' of the basement-cover interface is clearly spatially associated with low-angle basement shear zones distributed over large thickness, and therefore linked to non-coaxial shearing in the basement, instead of true folding. 
To conclude, basement-cored folding may be achieved by very different mechanisms depending on the rheological properties of the basement/cover rocks and the physical conditions of deformation $(P, T$, fluids). True basement folding is very rare and requires very specific conditions (e.g. well-oriented foliations) to occur, as shown above for the case of the Sierra Pie de Palo. In general, one faces cases of strain distribution, different from real folding and that are related to possible fluid circulation (e.g. Beaudoin et al. 2011), thermal synorogenic weakening (Bellahsen et al. 2012) or shear zones ahead of a thrust tip (Erslev, 1986, 1991; Bump, 2003; Garcia \& Davis, 2004).

\section{Rheological aspects of basement-involved shortening and importance of structural/thermal inheritance}

This section aims at discussing the possible control exerted by the rheology of the crust/lithosphere at the time of shortening on the structural style in FTBs.

\section{8.a. Role of the intrinsic rheological structure of passive margins}

Passive margins are key players in the collisional processes as the arrival of their proximal, poorly thinned parts into the subduction zone mark the onset of collision. The transition between continental and oceanic crusts is often marked by a wide domain of progressively thinner continental crust, with occasionally extensional upper crustal allochthons sheared off their lower crust and locally exhumed sub-continental mantle. Differential stretching of the lithosphere modifies its rheological properties (Fig. 14b), which will subsequently control deformation style during collision (Cloetingh et al. 2005). As the crust thins and cools during progressive rifting, the reduction in overburden pressure and temperature makes the rocks which originally deformed by plastic creep gradually become more prone to brittle failure. The result is that the initial weak zones in the middle crust and deep crust disappear and that the entire crust becomes brittle (Fig. 14a). The important consequences of the progressive embrittlement of originally ductile rocks during lithospheric extension are (1) that lateral flow or displacement of particular layers within the crust should become progressively more difficult as rifting proceeds, and (2) that the upper crust becomes coupled to the mantle (Reston \& Manatschal, 2011).

Summarizing, the occurrence of weak mechanical layers within the proximal passive margin lithosphere (the middle and most of the lower crust are expectedly ductile) (Fig. 14b) may therefore explain that subsequent contractional deformation will be distributed within most of the crust, giving rise to FTBs exhibiting a basement-involved tectonic style. In contrast, because these weak crustal levels are usually lacking in distal parts of the margins as a result of thinning, these stronger lithospheric domains are more prone to local- ized deformation in a continental subduction style. Noticeably, extensional upper crustal allochthons sheared off their lower crust during the rifting phase and subsequently shortened during collision may give rise to very thin basement nappes, as encountered in the Alps (Pfiffner, 2016, this issue) as a result of Mesozoic rifting and hyper-extension (Mohn et al. 2011).

\section{8.b. Role of pre-orogenic lithospheric thermotectonic inheritance}

Correlation between spatial variations of the flexural rigidity of the lithosphere and the nature and amount of foreland deformation has been suggested for the Andes FTB (Watts et al. 1995) and Taiwan (Mouthereau \& Petit, 2003). These authors documented that regions with low Equivalent Elastic Thickness (Te) correlate with thick-skinned deformation whereas regions with high Te correlate with thin-skinned deformation. The underlying idea is that a strong lithosphere is less easily deformed so that shortening is localized in a narrow zone at shallow depth, while a weaker lithosphere enables crust-mantle decoupling and shortening of the whole crust. Mouthereau \& Petit (2003) emphasized that the local increase in plate coupling and inhomogeneities in a prefractured margin as in Taiwan (see Section 3) can affect the rigidity of the layered continental lithosphere, supporting a mechanical relationship between its strength and the structural style.

In foreland domains that did not undergo significant syn-collisional burial and heating, the age-dependent properties of the passive margin lithosphere at the time of its involvement in collisional deformation are key to explaining variations in the accommodation of continental deformation in external parts of orogens. Two distinct groups of orogens have been distinguished (Mouthereau, Watts \& Burov, 2013; Fig. 15). The first group is characterized by high crustal strain (up to $70 \%$ ) with deformation localized above a shallow décollement in the weak sedimentary cover, i.e. overall localized, simple-shear-type deformation (subduction style). This type is commonly associated with old $(>1 \mathrm{Ga}$ ), cold and strong cratonic lithosphere, where the subducted lower crust is coupled with the mantle. The second group is characterized by limited crustal strain $(<40 \%)$, revealing that deformation is distributed within the entire crust, with brittle crustal thrust ramps in the upper crust and flow in the ductile middlelower crust, i.e. distributed, pure-shear-type deformation (collision style). This second type appears to be more commonly observed in FTBs built on young, hot and weak Phanerozoic lithosphere. These differences reflect the dependence of the lower crust and mantle strength on lithosphere thermal age (i.e. age of the last thermal event that led to modifying the thermal, hence rheological, state of the lithosphere; Mouthereau, Watts \& Burov, 2013; Fig. 15).

One main implication is that in external orogenic domains, where syn-collisional burial is limited and transient deformation and dynamic weakening processes 

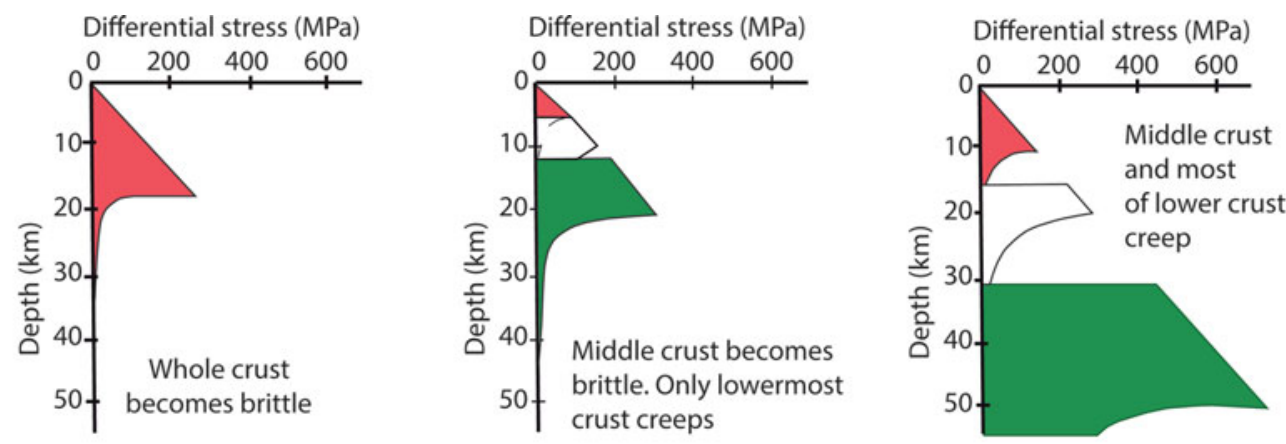

a

\section{Stretched, thinned crust. Crust coupled to mantle}

Increasing crustal thinning, increasing crust-mantle coupling while crust becomes more and more brittle
Unstretched, unthinned crust. Crust decoupled from mantle

b Passive margin Continent

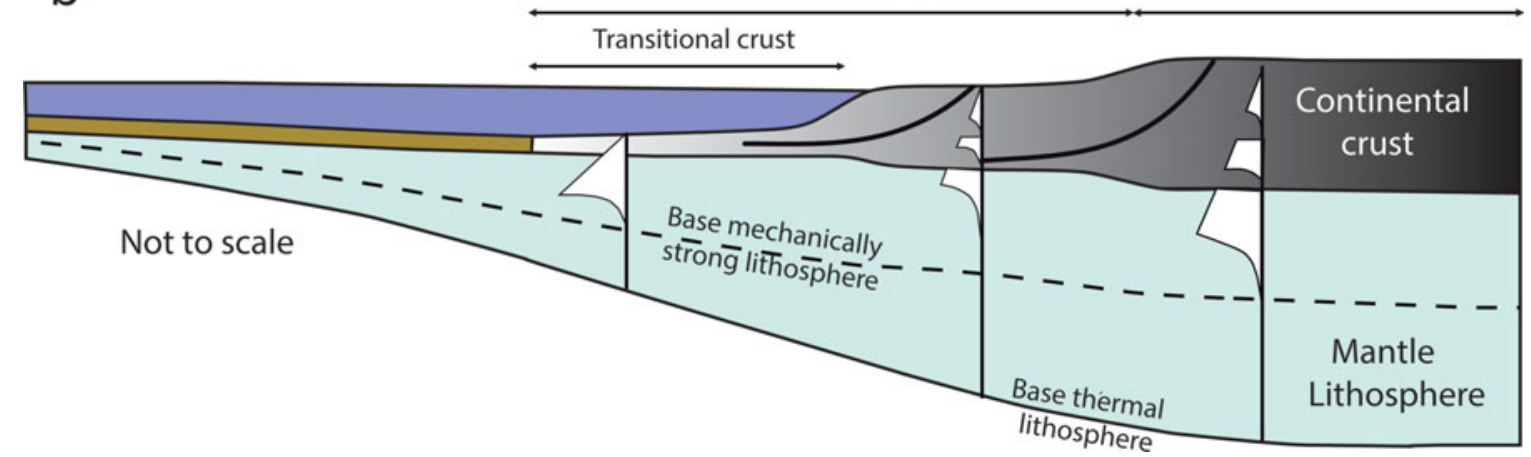

Figure 14. (Colour online) Change of lithospheric rheology during stretching and thinning during passive margin formation, which will subsequently control deformation style during collision. (a) Rheological model for a passive margin, emphasizing the effects of thinning and stretching of the lithosphere that lead to the disappearance of ductile middle and lower crust and embrittlement of the crust that is coupled to the mantle (modified after Reston \& Manatschal, 2011). (b) Change in rheological properties of the lithosphere as a result of differential stretching (modified after Cloetingh et al. 2005).

do not significantly alter the pre-collisional rheological layering, shortening of young lithosphere leads to basement-involved (thick-skinned) deformation, which reflects decoupling at the brittle-ductile transition or in the viscous lower crust.

The thermal state inherited from the last pre-orogenic rifting event has been further investigated by means of low-temperature thermochronology in the Pyrenees (Vacherat et al. 2014). These authors have shown that the high geothermal gradient related to Cretaceous hyper-extension and mantle exhumation lasted $30 \mathrm{Ma}$ after the onset of convergence at $\sim 83 \mathrm{Ma}$ and was relaxed during the 'collision' phase from $\sim 50 \mathrm{Ma}$. They further proposed that heat needed for ductile shortening during convergence in the NPZ has been primarily inherited from extension rather than being only related to tectonic and/or sedimentary burial. This study highlights how high temperatures inherited from the rifting event can affect the thermal structure of the crust during the early stages of mountain building. This hot crust was likely more prone to distributed deformation, hence thick-skinned tectonics, with or without reactivation of inherited normal faults.

Numerical modelling studies have recently addressed the structural style of mountain belts and have shown that the rheology of the basement-cover sequence and the rheological layering of the lithosphere have a strong control on this style (Jammes \& Huismans, 2012; Nilfouroushan et al. 2013; Bauville \& Schmalholz, 2015). Jammes \& Huismans (2012) showed by means of a 2D thermomechanical modelling approach that the relative strength of the frictionalplastic and viscous rheologies in the lithosphere affects the way it deforms in orogenic settings. Among the results pertaining to FTBs are: (1) systems with a weak upper and lower crust show deformation accommodated on a few thick-skinned crustal-scale thrusts with moderate displacement and by distributed thickening of the crust, as in the Zagros; (2) crustal systems characterized by a shallow decoupling zone in the mid-crust resulting from a thick and strong lower crust allows the formation of long thrust sheets and of an antiformal 

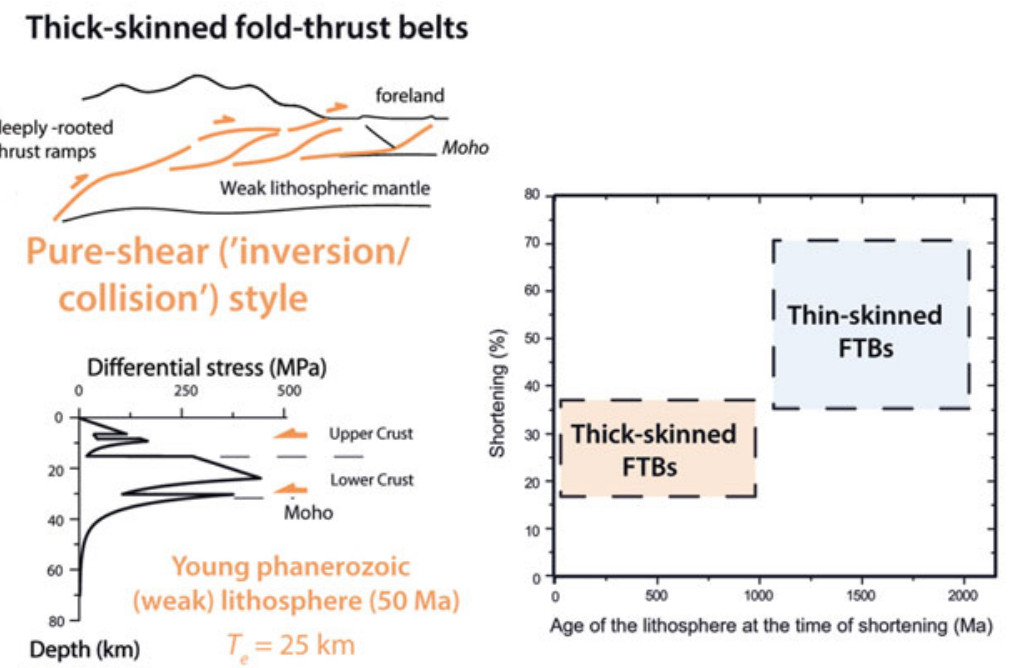

\section{Thin-skinned fold-thrust belts}

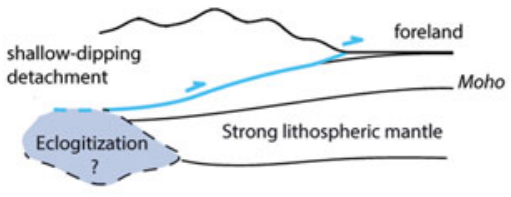

Simple-shear ('subduction') style

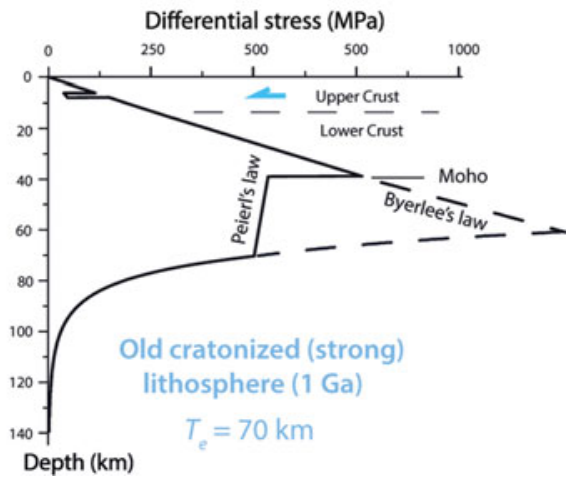

Figure 15. (Colour online) Distinct groups of orogens recognized by Mouthereau, Watts \& Burov (2013) on the basis of the style of deformation, percentage of shortening in foreland FTBs that did not undergo significant syn-collisional burial and heating, and the thermotectonic age of the lithosphere at the time of its involvement in collisional deformation. The first group is characterized by high crustal strain (up to $70 \%$ ) and is observed within old (>1 Ga), cold and strong cratonic lithosphere. The second group is characterized by limited crustal strain $(<40 \%)$ and is observed within young, hot and weak Phanerozoic lithosphere. Modified after Mouthereau, Watts \& Burov (2013).

stack in the core of the orogen, as in the Pyrenees; and (3) weaknesses inherited from extensional deformation in the internal part of the chain affect the structure of the orogenic wedge and facilitate the propagation of the deformation in the external part of the chain.

\section{8.c. Role of syn-convergence heating, hydration and ductilization}

An alternative situation arises when the inner part of the foreland domain is buried and heated during convergence or when a particular setting like flat-slab subduction modifies the rheology of the overlying lithosphere. In this case, the inherited thermal-tectonic state of the lithosphere may be modified by subsequent heating or hydration, providing the crust/lithosphere with new rheological properties at the time of shortening.

In the western Alps, ductilization of the European crust underthrust below the Penninic units occurred under greenschist conditions at about $300-330^{\circ} \mathrm{C}$ with a rather long-lasting peak temperature $(\sim 10 \mathrm{Ma}$ : Bellanger et al. 2015). This ductilization likely provided favourable conditions for distributed shortening (Bellahsen et al. 2012, 2014) as illustrated in Figure 9c1, c2 in the ECMs. Later on, the ductilely deformed crust was exhumed by motion along localized frontal thrust ramps that connected and likely activated basal décollement of the cover nappes in the sub-alpine/Helvetic thin-skinned FTBs. The numerical simulations by Bauville \& Schmalholz (2015) of the compression of a basement-cover system with half-grabens showed that (1) the transition between thin-skinned- and thick- skinned-dominated deformation is controlled by two effective viscosity ratios: the ratio inside the basement, that is the ratio of viscosity at the top of the basement to the viscosity at the bottom of basement, and the ratio of the viscosity at the top of the basement to the viscosity of the sedimentary cover directly above the basement, and (2) a higher basement-internal ratio favours thick-skinned deformation whereas a higher basementcover ratio favours thin-skinned deformation. Applying their results to the Alpine Helvetic nappes of Switzerland, these authors demonstrated that formation of fold nappes (e.g. Morcles nappe) is associated with thickskinned-dominated deformation whereas the formation of thrust nappes is instead related to thin-skinneddominated deformation. This emphasizes the combined weakening effects of inherited extensional basins and burial on the crust that favour thick-skinned deformation (Bellahsen et al. 2012).

Taking into account the thermal-structuralrheological state of the crust at the time of shortening provides predictive insights into the way basement-involved, thick-skinned deformation may occur, namely with or without inversion tectonics. As suggested by Figure 16, partly inspired by the papers by Butler, Tavarnelli \& Grasso (2006) and Bellahsen et al. (2012), the thermo-rheological state of the crust at the time of shortening, either inherited from preorogenic rifting events or later modified by early synconvergence burial, has important consequences on the mode of deformation. Assuming a given reference strength of the crust (Fig. 16a), reactivation of inherited normal faults (as observed in the Taiwan and 


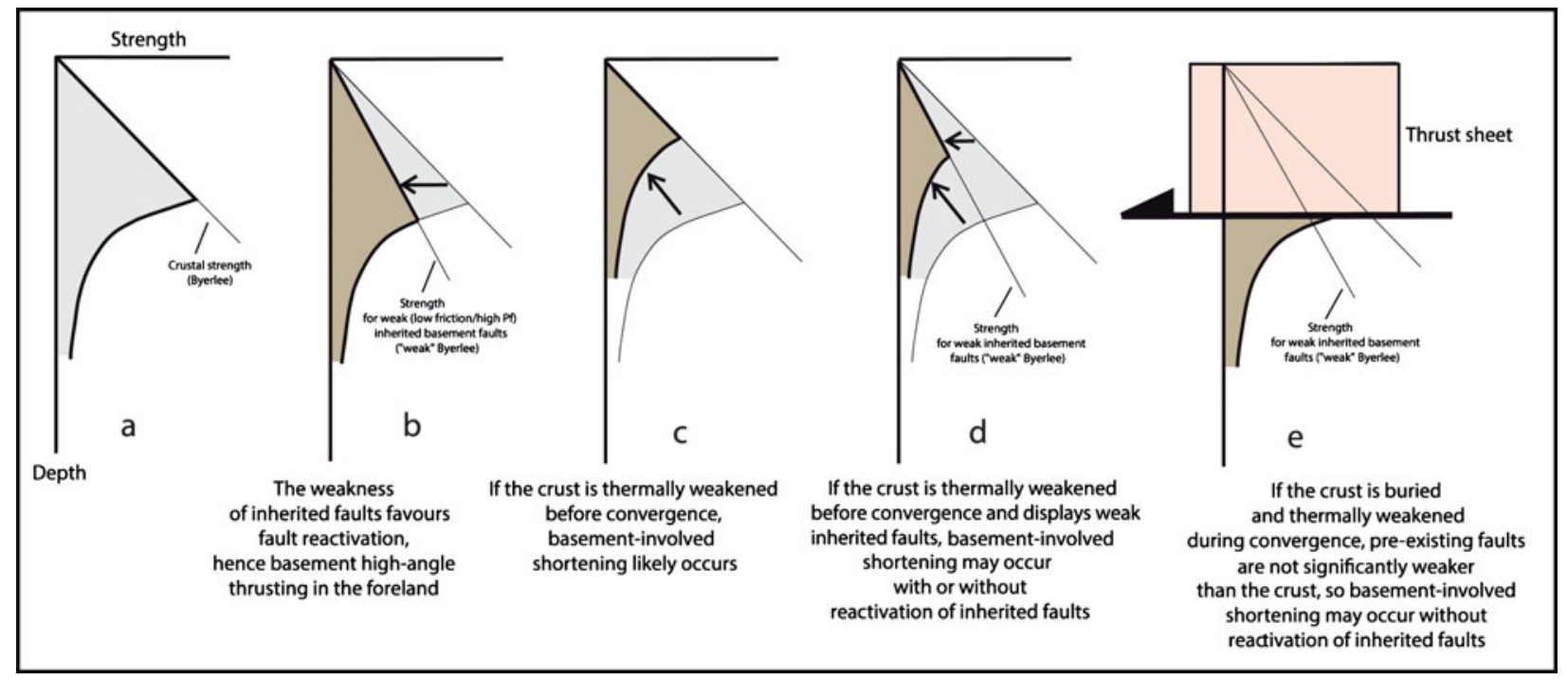

Figure 16. (Colour online) Schematic rheological profiles of the continental crust illustrating possible thermal and structural weakening that may lead to thick-skinned deformation, with or without inversion tectonics.

Laramide foreland) may be related to an abnormal weakness (weak Byerlee) of fault zones caused by local high fluid pressures or weak fault rocks (e.g. Imber et al. 1997, 2001; Steward, Holdsworth \& Strachan, 2000; Wibberley, 2005) leading to high-angle thrusting (Fig. 16b). Thermal weakening of the crust before convergence likely promotes distributed thick-skinned compressional tectonics (Fig. 16c). If the crust was thermally weakened before convergence and displays weak inherited faults (as for instance in the NPZ), basement-involved thick-skinned tectonics will expectedly occur with or without reactivation of inherited faults (Fig. 16d). Finally, if the crust has been buried and thermally weakened during convergence (as in the western Alpine ECMs), pre-existing faults are not significantly weaker than the crust, so basement-involved shortening may occur without reactivation of inherited faults (Fig. 16e).

At the time of the Laramide orogeny, the North American lithosphere was presumably cool and thick, with brittle failure prevailing down to more than $20 \mathrm{~km}$ depth (Fig. 11c) and limited ductile flow in the cool crust (see Section 6; Yonkee \& Weil, 2015). Depending on its composition - felsic or mafic granulites the lower crust may have been either moderately weak with potential concentration of ductile flow along deep décollements or strong with potential for lithospheric buckling (Yonkee \& Weil, 2015). Flat-slab subduction likely changed the strength of the mantle lithosphere as a result of the competing effects of cooling that favours increased strength and stress transfer - and hydration that decreases strength and enhances removal of mantle lithosphere. Humphreys et al. (2003) proposed that slab de-watering under the increasingly cool conditions of slab contact with North America hydrated the base of the continental lithosphere, causing a steady regional uplift of the western US during the Laramide orogeny. In addition, magmatic ascent heated and weakened the lithosphere, which allowed horizontal shortening to occur in the mantle beneath the region of Laramide thrusting in the southern Rocky Mountains, possibly promoting crustal shortening there. In the Rocky Mountains of Wyoming, however, most of the mantle lithosphere remained strong during the Laramide orogeny over distances of several hundred kilometres (Humphreys et al. 2003), so that lithospheric shortening may have occurred at locations quite distant from the areas of crustal shortening, which implies decoupling between upper crust and mantle within the upper plate.

To conclude, basement-involved shortening in orogenic forelands occurs under specific rheological states, such as occurrence of a ductile middle or lower crust, more likely found in proximal parts of passive margins of young and hot lithosphere, hence enabling crust-mantle decoupling. Thermal inheritance from the last pre-orogenic rifting event and/or early orogenic thermal weakening of the crust/lithospheric mantle are key factors controlling deformation style. Intervening particular boundary conditions like flat-slab subduction may increase interplate coupling (see Section 9.b), hence efficient stress transmission in the far foreland, which, together with structural crustal inheritance and possible mantle weakening, may provide an explanation for diffuse intraplate basement-involved shortening in a retro-wedge setting (Laramide, Sierras Pampeanas).

\section{Influence of boundary conditions and of the dynamics of orogenic wedges on the occurrence of foreland thick-skinned deformation}

In addition to rheological parameters, including structural, thermal and/or compositional weakening, tectonic inversion / thick-skinned deformation occurring in the far foreland likely requires specific boundary conditions ensuring efficient transmission of stresses (crustal/lithospheric stress guide) and propagation of 
deformation in the pro- or retro-foreland. The nature of stress transfer leading to shortening in the upper plate far away from the plate boundary is not only highly dependent on mantle and crustal rheology, and thus on thermal state, fluids and basement rock types, but also on the degree of interplate coupling.

\section{9.a. Influence of the geodynamic setting}

The control exerted on the occurrence of thick-skinned deformation by the geodynamic setting, especially the behaviour of subduction zones (advancing, where overriding plate motion is greater than the rate of trench migration, resulting in retro-arc contraction; or retreating, where the rate of trench roll back is greater than the margin-normal absolute motion of the overriding plate, resulting in back-arc extension) has been recently discussed by Nemcok, Mora \& Cosgrove (2013). When the orogens formed in the two subduction settings are considered and divided each into pro- and retrowedge cases, one can estimate qualitatively the energy budgets involved in their development and the intensity of deformation. Accordingly, the thick-skinned regions of pro-wedges group into 'forceful orogens', located in orogens at advancing subduction zones (e.g. Ouachitas, Southern and western Alps), and 'weak orogens', located in orogens at retreating subduction zones (e.g. Apennines, Balkans, Carpathians). This distinction is not relevant for the thick-skinned regions of retro-wedges that are all located on the retro-side of the orogens developed at advancing subduction zones. Nemcok, Mora \& Cosgrove (2013) concluded that an energy balance somewhat controls the presence or absence of thick-skinned domains along pro-wedges, retro-wedges and contracted intra-cratonic rift systems.

As also highlighted by Nemcok, Mora \& Cosgrove (2013), unlike basement involvement documented in the western Alps that formed at an advancing subduction zone, thick-skinned tectonics occurred during the latest stages of thin-skinned tectonics in regions like the Balkans or the Carpathians (Nemcok et al. 2006; Stuart et al. 2011). There, the depth range of thick-skinned tectonics is much lower than the depth of basement nappe formation in the western Alps. This may again indicate different - although still poorly understood controls for orogens formed at retreating subduction zones compared with those formed at advancing subduction zones.

\section{9.b. Influence of the degree of orogen-foreland / interplate coupling and transmission of compressional stresses}

Tectonic inversion occurring far into the pro- or retroforeland, or development of thick-skinned belts within cratons require both efficient transmission of orogenic stresses and accommodation of deformation. The transmission of stresses requires that the orogenic stresses are transferred to the upper plate and then transmitted far into its interior, using a crustal and/or a lithospheric stress guide. Propagation and accommodation of de- formation likely requires crustal/lithospheric buckling or deep crustal décollement (e.g. Lacombe \& Mouthereau, 1999, 2002; see also Section 6.a).

Regarding stress transfer, flat-slab subduction at an advancing subduction zone, possibly enhanced by increased coupling along a cratonic lithosphere root, is likely the most efficient setting as suggested by the similar settings of the Sierras Pampeanas and the Laramide uplifts.

A second controlling factor of occurrence of thickskinned tectonics far into the foreland is the degree of coupling between the orogen and its foreland. Mechanical coupling at plate boundaries has obvious implications for transmission of stresses within the lithosphere and the resulting strain. Mechanical coupling between orogenic wedges and adjacent plates likely changes through time, for instance as lubrication of the subduction interface (due to sediment and/or fluid availability) decreases, as thermally driven softening by shear heating decreases, or even as the buoyancy of the incoming continental lithosphere that resists subduction increases (Faccenda et al. 2008). Even orogens characterized by high convergence rates, such as the Rocky Mountains in Alberta, can lack basement uplifts or any kind of compressional intraplate deformation in their foreland if the foreland does not contain any major intraplate discontinuities, or if it lacks mechanical coupling with the orogen (Ziegler, 1989).

Buckling of the lithosphere is possibly an efficient way to propagate deformation into the upper plate. Weakening by either hydration or heating by magmatic ascent likely favours horizontal shortening occurring in the mantle through buckling, associated with (or causing?) thrusting in the crust above mantle lithosphere folds. Taking into account the Rocky Mountain arch wavelengths (e.g. Erslev, 2005; Yeck et al. 2014), biharmonic-decoupled lithospheric buckling folding of the upper crust and folding of the mantle lithosphere with different wavelengths - is more likely than monoharmonic lithospheric buckling with crustmantle coupling (Fig. 11d). In the case that the lithosphere remains strong and rigid, crustal shortening requires a crustal décollement which at least partially decouples the uppermost crustal levels from the deeper lithosphere (Lacombe \& Mouthereau, 1999, 2002; Fig. 11d). Geodynamic modelling of collision tectonics (Pfiffner, Ellis \& Beaumont, 2000) has shown that mid-crustal weak inclusions within the underthrusted lithosphere cause limited decoupling at the mid-crust and localize proward shear. Models of structural inversion in forelands often involve a (mid-)crustal weak zone above which basement high-angle thrusting occurs, this weak zone being possibly inherited from a previous mid-crustal extensional flat décollement (e.g. Cristallini \& Ramos, 2000; Marshak, Karlstrom \& Timmons, 2000). In the outermost Alpine foreland, a décollement in the basement probably accommodated inversion of Permo-Carboniferous grabens underlying the Mesozoic cover (Fig. 10b). A similar situation is met in the Taiwan foreland where a décollement at 
$\sim 25 \mathrm{~km}$ depth (Fig. 8) probably accommodated offshore basin inversion and inversion of pre-existing normal faults. The recent geophysical investigations in the Bighorn Mountain region by Yeck et al. (2014) and Worthington et al. (2016) also suggested that midcrustal décollement, together with fault-propagation folding, was the primary mechanism for building Laramide basement-involved foreland arches. Finally, the lower crustal imbricates imaged on the ECORS Pyrenees profile on the Spanish side (Roure et al. 1989) account for a recent thickening of the Iberian crust compared to the Aquitaine crust (French side) where the lower crust is thinner and well layered, without such imbricates. This likely indicates the possible occurrence of a lateral ductile flow of the lower crust in the lower plate, allowing for long distance decoupling within the foreland and intraplate inversions away from the plate boundary (F. Roure, pers. comm, 2015). It is noticeable that thick-skinned deformation and shallow décollement tectonics may occur simultaneously (Zagros), which leads to definitely ruling out the idea that thick-skinned tectonics (only) occurs in the absence of potential shallow décollement in or at the base of the sedimentary cover.

The consequences of mechanical (de)coupling between weak orogenic wedges and strong adjacent foreland plates were investigated by means of lithospheric-scale analogue modelling (Willingshofer \& Sokoutis, 2009). Experimental results show that when the foreland and the orogenic wedge are decoupled, shortening is mainly taken up along the main overthrust, the decoupled boundary and within the orogenic wedge, leaving the indenter devoid of deformation. In contrast, strong mechanical coupling between the foreland and the orogenic wedge favours deformation of the lithosphere by buckling, involving both the weak zone and the strong plates. Increasing the degree of plate coupling, or the presence of decoupling horizons within the upper plate, reduces the efficiency of subduction, and convergence is accommodated partly by deformation of the upper plate (and also by thickening of the slab) (Willingshofer et al. 2013). In contrast to weak plate-interface coupling, strong coupling at the plate interface leads to more complex and narrow crustal geometries in the lower plate and facilitates deformation of the upper plate. Additionally, the experiments confirm that the presence of decoupling horizons within the upper plate promotes the transfer of strain to the overriding plate and is thus key to understanding upper-plate deformation.

Summarizing, under conditions of mechanical coupling between an orogenic wedge and its foreland at crustal and/or lithospheric levels, or interplate coupling along a cratonic lithosphere root, compressional stresses can be transmitted into the foreland. Rheologically weak layers are consequently activated as décollement horizons, inducing the reactivation of preexisting crustal discontinuities and/or broad crustal and lithosphere folding at great distances from the collision front (Ziegler, Bertotti \& Cloetingh, 2002). For a given degree of coupling, the response of the foreland crust/lithosphere to the far-field stress transmission strongly depends on its thickness, thermal regime and fluid content.

\section{9.c. Influence of the dynamics of the orogenic wedge}

Occurrence of basement-involved shortening is also seemingly promoted by the intrinsic dynamics of the evolving orogenic wedge.

In the weak pro-wedges of the Carpathians and the Balkans, thick-skinned tectonics occurred during a late stage of the orogenic build-up, when the taper angle was high, the thermal regime was elevated and an extra mechanism for out-of-sequence shortening was required to further increase the orogenic taper (see Nemcok et al. 2006; Stuart et al. 2011).

The Andean Eastern Cordillera, a forceful retrowedge detached at a depth of about $30 \mathrm{~km}$ (Mora et al. 2008, 2010; Parra et al. 2009a,b), indicates that thickskinned deformation occurs at stages when the orogenic foreland is unable to flex under the advancing orogen so that the orogen needs to build up extra strength in order to advance any further (Hermeston \& Nemcok, 2013). Similarly, the narrow foreland plates of the Kura Valley basin, trapped between two orogens moving towards each other (Greater and Lesser Caucasus), is affected by thick-skinned deformation (Nemcok et al. 2013).

In the Alps-Jura system, the deformation of the Jura FTB and the Molasse basin over a basal décollement was followed by the development of new crustal imbricates and the associated out-of-sequence thrusting to regain a stable orogenic wedge geometry (Mosar, 1999).

In Taiwan, the thrust front seemingly propagated preferentially as a thick-skinned structure where preorogenic basins were present and as a thin-skinned structure where those were absent (Section 3). In the inner zones of the western FTB where topographic elevation is significant, deformation involves both thin-skinned and thick-skinned styles. According to Mouthereau \& Lacombe (2006), this internal deformation of the thrust wedge occurs by out-of sequence thrusting (e.g. Chelungpu-Sani thrust), possibly in order to maintain a relative balance between compressional stresses in the crust, arising from the convergence, and the topography.

It thus seems that the evolution towards a thickskinned tectonic style of deformation may reflect in some cases a necessary step to achieve a stable (steadystate?) orogenic system after cessation or even during the latest stages of thin-skinned deformation, in response to ongoing convergence.

\section{Interactions between basement-involved shortening and syntectonic sedimentation in (broken) forelands}

Broken forelands are an integral part of many orogens (Hain et al. 2011). Modern examples of broken 
foreland basins are parts of the Colombian Andes (e.g. Mora et al. 2006, 2009; Parra et al. 2009a,b), the Tian Shan (e.g. Sobel \& Dumitru, 1997; Sobel, Hilley \& Strecker, 2003; Kober et al. 2013), the Qilian Shan (e.g. Tapponnier et al. 1990), the Santa Barbara system of northwestern Argentina and the Sierras Pampeanas provinces further south (e.g. Allmendinger et al. 1983; Jordan \& Allmendinger, 1986). Ancient analogues of broken forelands are the Cretaceous-Eocene Laramide foreland of the western US (Dickinson \& Snyder, 1978; Jordan \& Allmendinger, 1986; Dickinson et al. 1988; Davis et al. 2009; Ernst, 2010) and the Palaeozoic Alice Springs broken foreland in Australia (Haines, Hand \& Sandiford, 2001). In contrast to 'typical' (continuous) foreland basins associated with thin-skinned FTBs, shortening in broken forelands is accommodated by spatially disparate, diachronous basement uplifts bounded by high-angle thrusts and separated by broad basins.

10.a. Control of foreland basement faulting on syntectonic sedimentation: the Laramide broken foreland

In broken forelands, patterns of deformation, sediment routing and accumulation are different from thinskinned FTBs (e.g. DeCelles \& Giles, 1996) and may be characterized by highly disparate spatio-temporal patterns of deformation and sedimentation (e.g. Hain et al. 2011; Strecker et al. 2012).

This mode of foreland basin evolution usually compartmentalizes a formerly contiguous sedimentary basin and often causes specific trends in rock uplift and sedimentation patterns. In the Rocky Mountain region, sedimentologically isolated nonmarine basins were produced by basement deformation during the Laramide orogeny within the area formerly occupied by a broad Late Cretaceous foreland basin in which laterally continuous marine facies had accumulated (Dickinson et al. 1988). These highly localized intermontane basins are separated by strongly emergent basement-cored uplifts that tectonically fragmented the drainage system and served as local sources of coarse alluvial orogenic sediments (Dickinson, 1976). Studies of synorogenic conglomerates on the flanks of Laramide basins by DeCelles et al. $(1987,1991)$ and Hoy \& Ridgeway (1997) provided important insight into the kinematic and erosional evolution of these uplifts (Seager, Mack \& Lawton, 1997). The presence of lacustrine facies in basin fill indicates times during which structural and topographic relief between basins and adjacent Laramide uplifts was sufficient to pond water within the depocentres.

Accommodation of deformation within basement ranges and the formation of a broken foreland may occur well inboard of the primary topographic margin of the orogen (e.g. Allmendinger et al. 1983). Importantly, the uplift of such basement ranges leads to a different flexural response, hence a different evolution of associated depositional systems compared to the one expected in typical foreland basin systems related to a growing orogenic wedge (Cross, 1986). Because the crust is subdivided into short beams that can rotate about horizontal axes relative to one another, this rotation is a principal component of tectonic subsidence in addition to flexural loading. Laramide basin subsidence is thus related to the flexural effects of tectonic loads imposed on the lithosphere by thrust masses emplaced along the flanks of adjacent uplifts (Hagen, Shuster \& Furlong, 1985). For instance, the depocentre of the Upper Cretaceous in eastern Wyoming is presumably too far from the thrust belt to have been simply caused by loading and flexure and was likely controlled by Laramide basement uplifting.

The structural, geomorphic and depositional characteristics and dynamics of broken foreland basins on the eastern flanks of the central Andes in Bolivia and NW Argentina have been recently discussed by Strecker et al. (1989, 2012), Sobel \& Strecker (2003), Hain et al. (2011), Iaffa et al. (2013) and Davila \& Carter (2013). An important point is that the along-strike variations in the geometry of foreland basins are likely generated by the variability in the structure of the Andes, structural inheritance (e.g. Mescua et al. 2014) and/or the variable strength of the upper-plate lithosphere.

\section{0.b. Control of syntectonic sedimentation on foreland basement-involved deformation}

Based on numerical modelling, Erdos, Huismans \& van der Beek (2015) recently suggested an additional factor that may control the occurrence of basementinvolved shortening in forelands. The basic idea is that the minimum-work principle applies to basement thrusting, i.e. a new crustal thrust should occur at the locus where the total work required for slip on the viscous mid-crustal décollement and breakthrough to the surface is minimized. The main effect of syntectonic sedimentation is to increase the frictional work required to create a new thick-skinned crustal-scale thrust. Consequently, the formation of a new thrust is favoured where sediments taper out.

Numerical modelling supports that sediment loading on the external parts of an orogen may provide a firstorder control on its crustal-scale structural style and significantly changes its dynamics. In sediment-starved orogens, basement deformation is mostly limited to the axial orogenic zone with thin-skinned deformation in the adjacent foreland, whereas in sediment-loaded orogens, thick-skinned crustal-scale deformation with long basement thrust sheets occurs in both the Axial Zone and beneath the foreland (Erdos, Huismans \& van der Beek, 2015). Erosion, while strongly affecting the width of the orogenic core, appears to have limited direct effects on the evolution of the foreland.

The effect of synorogenic/syntectonic sedimentation on basement involvement in shortening in orogenic forelands as predicted by numerical models can be illustrated by natural field examples. The Ural Mountains (central Russia) is a collisional belt formed during Late Devonian to Late Permian - Early Triassic 
times (Brown et al. 1997). The kinematic evolution consists of two forward-propagating thrust sequences, with imbricates of Precambrian basement and Palaeozoic cover; the amount of shortening is small and the basement thrust sheets show a spacing of about $10 \mathrm{~km}$ (Brown et al. 1997, 1999). Overall, the Urals show little or no basement deformation below the foreland, and the whole orogen is relatively narrow as a result of basement deformation being restricted to the central orogenic core. These characteristics are those predicted by numerical models (Erdos, Huismans \& van der Beek, 2015) for a very limited thickness of syntectonic deposits, which is the case for the sedimentstarved Ural orogen. In contrast, the Swiss Alps along the Jura section (Fig. 10a, b) display long basement thrust sheets (up to $\sim 50 \mathrm{~km}$ ) (Fig. 10b) below thick foreland basin deposits, up to $4 \mathrm{~km}$ (Burkhard \& Sommaruga, 1998) and possibly up to $8 \mathrm{~km}$ even now partly eroded (Bonnet, Malavieille \& Mosar, 2007). In agreement with numerical models, the Swiss Alps orogenic wedge is larger than the Urals as a result of thick-skinned basement deformation below the foreland.

To conclude, although the long basement thrust sheets as documented in numerical models are likely different from localized basement uplifts of broken forelands, one can nevertheless expect a mutual control between thick-skinned deformation in FTBs and sediment deposition leading to burial in forelands: basement thrusts beneath the foreland are favoured in the case of sediment-loaded orogens, and in turn basement thrusts strongly influence the local pattern of uplift, erosion and sedimentation.

\section{Sequence of deformation and relationships between thick-skinned and thin-skinned tectonic styles in space and time}

In this section, we only attempt to discuss the sequence of thick-skinned deformation and its relationships in space and time with thin-skinned deformation in foreland FTBs, irrespective of the absolute timing of thick-skinned deformation in the reviewed orogens.

On the basis of the examples reviewed here, we state that different spatial and temporal relationships between the two tectonic styles are encountered, preventing formulation of any simple rule on their occurrence.

Case 1: Early inversion of inherited normal faults in the foreland leading to high-angle basement thrusting prior to thin-skinned deformation (Fig. 17a): In the Zagros and in Taiwan for instance, early compressional/transpressional inversion of preexisting normal faults of the Arabian and southeastern Chinese passive margins, respectively, occurred far in the foreland before frontal thin-skinned thrusts were activated (Lacombe \& Mouthereau, 2002; Lacombe et al. 2003; Ahmadhadi, Lacombe \& Daniel, 2007). These early movements along steeply dipping faults, however, accommodated a small amount of shortening.

Case 2: Early basement shortening, then activation of outer thin-skinned deformation coeval with exhumation and forelandward transport of shortened basement (Fig. 17b): In the western Alps, at the latitude of Oisans for instance, basement-involved shortening occurred in the buried basement of the innermost external zone before thin-skinned deformation initiated in the frontal thin-skinned Vercors FTB (Fig. 17b). As discussed in Section 4.a, the later activation of the shallow décollement is related to thrusting along a localized frontal ramp that coevally transported westwards and exhumed the basement of the ECMs (Bellahsen et al. 2014).

Case 3: Mainly coeval thin-skinned and thickskinned deformation (Fig. 17c): There is to date a consensus that thin-skinned and thick-skinned styles of deformation are superimposed (as attested by seismicity) and occurred roughly coevally in the Zagros (Fars Province) (e.g. Oveisi et al. 2009; Mouthereau, Lacombe \& Verges, 2012), even though early basement faults may have been activated before cover folding (Fig. 17a) (e.g. Ahmadhadi, Lacombe \& Daniel, 2007) or late basement thrusts may offset thin-skinned structures in places (Molinaro et al. 2005; Sherkati, Letouzey \& Frizon de Lamotte, 2006). The cover is detached mainly above the low-viscosity Hormuz salt layer while the basement deforms by both seismogenic faulting and ductile aseismic shearing. As mentioned earlier, that thick-skinned deformation and shallow décollement tectonics may occur simultaneously leads to definitely ruling out the idea that thick-skinned tectonics (only) occurs in the absence of potential shallow décollement in or at the base of the sedimentary cover.

Case 4: Late (out-of-sequence) basement thrusting (Fig. 17d): In the Jura, thick-skinned thrusting related to reactivation of inherited Palaeozoic basins caused refolding of shallow thin-skinned nappes and present-day surface uplift. The same possibly occurs in the eastern Precordillera of western Argentina (e.g. Meigs et al. 2006). In Taiwan, out-of-sequence seismogenic basement faulting may occur below or across thin-skinned nappes.

Case 5: Late thick-skinned deformation forelandward (Fig. 17e): In the US Rockies, thick-skinned shortening gave rise to the Laramide arches in the foreland of the thin-skinned Sevier FTB. Thickskinned Laramide deformation occurred partly coevally with, and after, Sevier deformation. A similar setting is currently encountered in the active Sierras Pampeanas in the foreland of the Precordillera FTB of Argentina.

Inversion tectonics and basement-involved shortening may therefore occur at different stages of the tectonic evolution of FTBs, prior to thin-skinned deformation through inversion of inherited basement faults in the foreland, coevally with thin-skinned deformation or after thin-skinned tectonics. While thin-skinned 
Early inversion of inherited normal faults / early high angle basement thrusting in the foreland (Zagros, Taiwan)

a

w

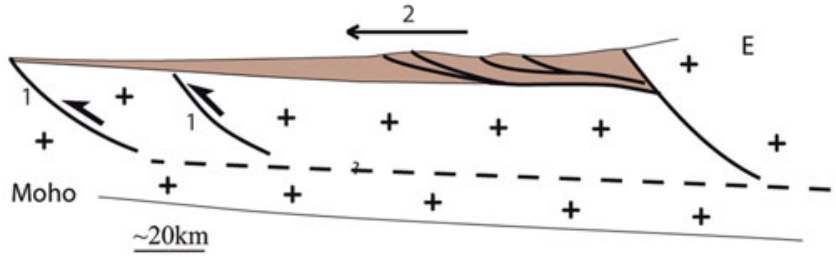

Basement shortening at the rear then exhumation and forelandward propagation above basement ramps activating cover shallow decollement (Western Alps)

b

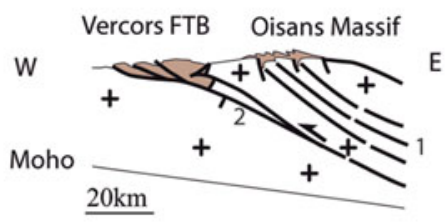

Coeval thin-skinned and thick-skinned tectonics.

The cover is detached mainly above the low-viscosity Hormuz salt layer while the basement deforms by both seismogenic faulting and ductile aseismic shearing (Zagros)

C

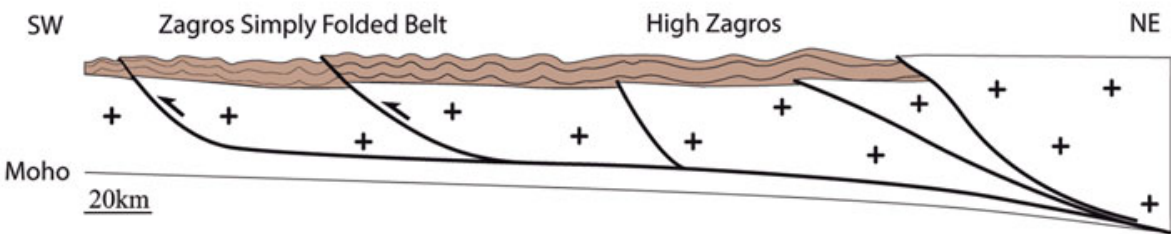

Late basement thrusting : refolding of shallow nappes by high angle thrusts reactivating inherited normal faults (e.g, Jura, Provence) /out-of-sequence seismogenic basement thrusting
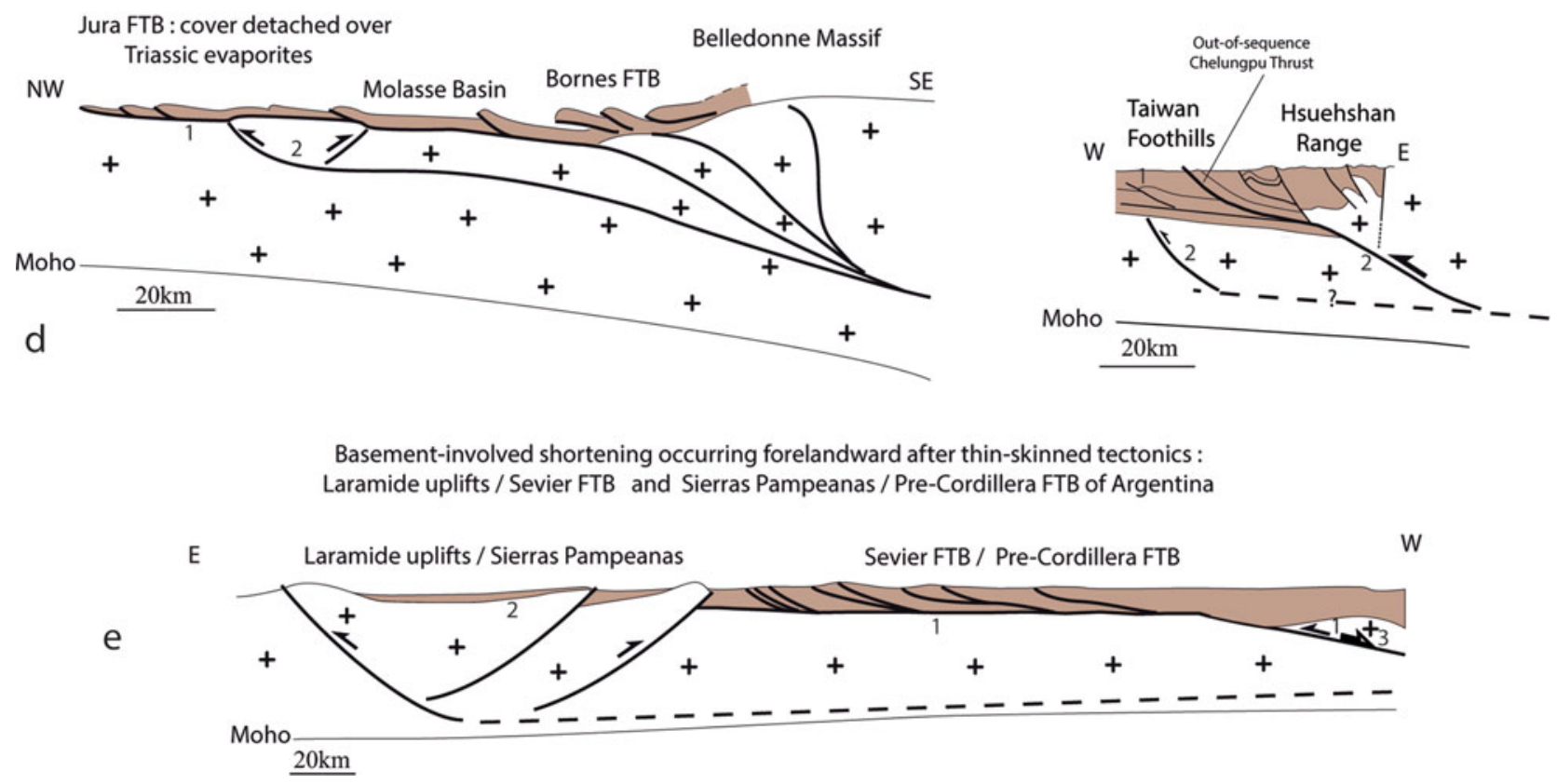

Figure 17. (Colour online) Different spatial and temporal relationships/sequences between thin-skinned and thick-skinned tectonics in FTBs.

systems usually form an orogenic wedge that propagates/accretes progressively outwards through time in a more or less continuous and regular fashion, thickskinned systems often display a more irregular and erratic sequence (e.g. Laramide, Sierras Pampeanas), possibly linked to the heterogeneous and complex transmission of orogenic stress and accommodation of shortening through the crystalline basement with inherited weaknesses and anisotropies.

\section{Conclusions}

FTBs mainly form either in lower and upper plates at the expense of proximal parts of former passive margins 
or intracontinental rifts during collision or within the upper plate of flat-slab subduction orogens. In contrast, inner parts of mountain belts are likely made of stacked units from the distal passive margin domains that have undergone continental subduction and high-pressure low-temperature metamorphism.

There are increasing lines of evidence of basementinvolved shortening in FTBs, even in the 'archetypal' thin-skinned belts. This basement involvement is often associated with basement inversion tectonics. Our review illustrates how the pre-orogenic deformation of the basement may control the geometry, kinematics and mechanics of FTBs, either at the scale of the whole belt (e.g. belt curvature, segmentation and alongstrike variations of structural styles, sequence of deformation, localization of contractional deformation and percentage of shortening) or at the scale of tectonic units (reactivation of inherited basement faults, basement-cored folding). In some cases, however, inherited basement (normal) faults are not reactivated whereas newly formed compressional shear zones develop, which brings into question the bulk rheology of the crust versus the rheology of pre-existing fault zones available for reactivation.

In basement-involved, thick-skinned FTBs, shortening is distributed throughout the whole crust and is usually lower than in their thin-skinned counterparts, which likely requires/reflects a specific thermomechanical behaviour of the underlying lithosphere (e.g. hot and young, hence weak). In FTBs resulting from inversion of former proximal passive margins, basement thrusting that occurs in a rather localized way in their inner parts requires structural inheritance and/or a hot crustal temperature either inherited from a recent (pre-orogenic) rifting event or resulting from synorogenic underthrusting and heating.

Basement involvement in FTBs raises the question of the way the orogen is mechanically coupled to the foreland and how orogenic stresses are transmitted through the heterogeneous basement of the foreland/plate interior. Development of thick-skinned belts within cratons remains somewhat enigmatic and likely requires specific boundary conditions (strong interplate coupling, such as provided by flat-slab subduction) ensuring efficient transmission of stresses (crustal/lithospheric stress guide) and propagation of deformation in the pro- and retro-foreland by crustal/lithospheric buckling or deep crustal décollement, in addition to local structural and/or possible physical/compositional weakening.

Whatever its control(s) (structural inheritance, thermal state, composition), the rheology of the continental lithosphere appears to be central to understanding mountain-building processes, and understanding the wide range in structural styles of FTBs and their relationships to crustal/lithospheric architecture/rheology will still remain a key area of research for years.

Acknowledgements. The authors would like to warmly thank P. Ryan, F. Roure and D. Brown for their constructive comments that greatly improved the manuscript, R. Chuang and $\mathrm{K}$. Johnson for kindly providing the original figure on the Nantou fault, G. Camanni and D. Brown for kindly providing the original figure on the Shuilikeng fault and V. Scisciani for kindly providing the original figure on structural styles in the Umbria-Marches.

\section{References}

Ahmadhadi, F., Lacombe, O. \& Daniel, J. M. 2007. Early reactivation of basement faults in Central Zagros (SW Iran): evidence from pre-folding fracture populations in the Asmari Formation and Lower Tertiary paleogeography. In Thrust Belts and Foreland Basins: From Fold Kinematics to Hydrocarbon Systems (eds O. Lacombe, J. Lavé, J. Vergés \& F. Roure), pp. 205-28. Frontiers in Earth Sciences. Berlin: Springer-Verlag.

Allaby, A. \& Allaby, M. (eds) 1991. The Concise Oxford Dictionary of Earth Sciences. Oxford: Oxford University Press, $410 \mathrm{pp}$.

Allen, M. B., SaVille, C., Blanc, E., Talebian, M. \& NISSEN, E. 2013. Orogenic plateau growth: expansion of the Turkish-Iranian Plateau across the Zagros foldand-thrust belt. Tectonics 32, 171-90.

ALlmENDINGER, R. W., JORDAN, T. E., KAY, S. M. \& ISACKS, B. L. 1997. The evolution of the Altiplano-Puna Plateau of the Central Andes. Annual Reviews of Earth and Planetary Sciences 25, 139-74.

Allmendinger, R. W., RAmos, V. A., JoRdan, T. E., PALma, M. \& ISACKS, B. L. 1983. Paleogeography and Andean structural geometry, northwest Argentina. Tectonics $\mathbf{2}$, $1-16$.

AlvarAdO, P., BECK, S. \& ZANDT, G. 2007. Crustal structure of the south-central Andes Cordillera and backarc region from regional waveform modeling. Geophysical Journal International 170, 858-75.

Alvarez-Marron, J., Brown, D., Camanni, G., Wu, Y. M. \& KUO-CHEN, H. 2014. Structural complexities in a foreland thrust belt inherited from the shelf-slope transition: insights from the Alishan area of Taiwan. Tectonics 33, 1322-39.

Ammirati, J.-B., Alvarado, P. \& BeCK, S. 2015. A lithospheric velocity model for the flat slab region of Argentina from joint inversion of Rayleigh wave phase velocity dispersion and teleseismic receiver functions. Geophysical Journal International 202, 224-41.

Ammirati, J.-B., Alvarado, P., Perarnau, M., Saez, M. \& Monsalvo, G. 2013. Crustal structure of the Central Precordillera of San Juan, Argentina $\left(31^{\circ} \mathrm{S}\right)$ using teleseismic receiver functions. Journal of South American Earth Sciences 46, 100-9.

Anderson, M., Alvarado, P., ZANDT, G. \& BECK, S. 2007. Geometry and brittle deformation of the subducting Nazca Plate, Central Chile and Argentina. Geophysical Journal International 171, 419-34.

ARISI ROTA, F. \& FICHERA, R. 1987. Magnetic interpretation related to geo-magnetic provinces: the Italian case history. Tectonophysics 138, 179-96.

BABY, P., RIVADENEIRA, M., BARRAGAN, R. \& Christophoul, F. 2013. Thick-skinned tectonics in the Oriente foreland basin of Ecuador. In Thick-SkinDominated Orogens: From Initial Inversion to Full Accretion (eds M. Nemcok, A. Mora \& J. Cosgrove), pp. 59-76. Geological Society of London, Special Publication no. 377. 
BAHROUDI, A. \& TALBOT, C. 2003. The configuration of the basement beneath the Zagros basin. Journal of Petroleum Geology 26, 257-82.

BAKER, C., JACKSON, J. \& PRIESTLEY, K. 1993. Earthquakes on the Kazerun Line in the Zagros Mountains of Iran: strike-slip faulting within a fold-and-thrust belt. Geophysical Journal International 115, 41-61.

Ballato, P., Uba, C. E., LANDGraf, A., Strecker, M. R., Sudo, M., Stockli, D., Friedrich, A. \& TABATABAeI, S. H. 2011. Arabia-Eurasia continental collision: insights from late Tertiary foreland basin evolution in the Alborz Mountains, northern Iran. Geological Society of America Bulletin 123, 106-31.

Bally, A., Burbi, W., CoOper, J. C. \& GHelardoni, L. 1986. Balanced sections and seismic reflection profiles across the Central Apennines. Memorie della Società Geologica Italiana 35, 257-310.

Barchi, M., Minelli, G. \& Pialli, G. P. 1998. The CROP 03 profile: a synthesis of results on deep structures of the Northern Apennines. Memorie della Società Geologica Italiana 52, 383-400.

BAuville, A. \& Schmalholz, S. M. 2015. Transition from thin- to thick-skinned tectonics and consequences for nappe formation: numerical simulations and applications to the Helvetic nappe system, Switzerland. Tectonophysics 665, 101-17.

BeAUdoin, N., BELlahSEN, N., LACOMBE, O. \& EMMANUEL, L. 2011. Fracture-controlled paleohydrogeology in a basement-cored, fault-related fold: Sheep Mountain anticline (Wyoming, USA). Geochemistry, Geophysics, Geosystems 12, Q06011, doi: 10.1029/2010GC003494.

BEAUdoIn, N., LEPRÊTRE, R., BELlahSEN, N., LACOMBE, O., Amrouch, K., CAllot, J. P., Emmanuel, L. \& Daniel, J. M. 2012. Structural and microstructural evolution of the Rattlesnake Mountain Anticline (Wyoming, USA): new insights into the Sevier and Laramide orogenic stress build-up in the Bighorn Basin. Tectonophysics 576-577, 20-45.

Beaumont, C., Munoz, J. A., Hamilton, J. \& Fullsack, P. 2000. Factors controlling the Alpine evolution of the central Pyrenees inferred from a comparison of observations and geodynamical models. Journal of Geophysical Research 105, 8121-45.

BECKER, A. 2000. The Jura Mountains: an active foreland fold-and-thrust belt? Tectonophysics 321, 381-406.

Bellahsen, N., Jolivet, L., Lacombe, O., Bellanger, M., Boutoux, A., Garcia, S., Mouthereau, F., Le POURHIET, L. \& GUMIAUX, C. 2012. Mechanisms of margin inversion in the external Western Alps: implications for crustal rheology. Tectonophysics 560-561, 6283.

Bellahsen, N., Mouthereau, F., Boutoux, A., Bellanger, M., Lacombe, O., Jolivet, L. \& Rolland, Y. 2014. Collision kinematics in the western external Alps. Tectonics 33, 1055-88.

Bellahsen, N., Sebrier, M. \& Siame, L. 2016. Crustal shortening at the Sierra Pie de Palo (Sierras Pampeanas, Argentina): near-surface basement folding and thrusting. In Tectonic Evolution and Mechanics of BasementInvolved Fold-and-Thrust Belts (eds O. Lacombe, J. Ruh, D. Brown \& F. Nilfouroushan). Geological Magazine.

Bellanger, M., Augier, R., Bellahsen, N., Jolivet, L., Monie, P., Baudin, T. \& Beyssac, O. 2015. Shortening of the European Dauphinois margin (Oisans Massif, Western Alps): new insights from RSCM maximum temperature estimates and Ar-40/Ar-39 in situ dating. Journal of Geodynamics 83, 37-64.
Bellanger, M., Bellahsen, N., Jolivet, L., Baudin, T. AugIER, R. \& BoutouX, A. 2014. Basement shear zones development and shortening kinematics in the Ecrins Massif, Western Alps. Tectonics 33, 84-111.

BERBERIAN, M. 1995. Master "blind" thrust faults hidden under the Zagros folds: active basement tectonics and surface tectonics surface morphotectonics. Tectonophysics 241, 193-224.

BERBERIAN, M. \& KING, G. C. P. 1981. Towards a paleogeography and tectonic evolution of Iran. Canadian Journal of Earth Sciences 18, 210-65.

Bestani, L., Espurt, N., Lamarche, J., Floquet, M., Philip, J., Bellier, O. \& Hollender, F. 2015. Structural style and evolution of the Pyrenean-Provence thrust belt, SE France. In Lithosphere Dynamics of Sedimentary Basins-The Circum-Mediterranean Basins and Analogues (eds M. Seranne, J. Lamarche \& F. Agosta). Bulletin de la Société géologique de France 186, 22341.

Beydoun, Z. R. 1991. Arabian Plate Hydrocarbon Geology and Potential - A Plate Tectonic Approach. AAPG Studies in Geology vol. 33. Tulsa: American Association of Petroleum Geologists.

Beydoun, Z. R., Clarke, M. W. H. \& Stoneley, R. 1992. Petroleum in the Zagros Basin; a late Tertiary foreland basin overprinted onto the outer edge of a vast hydrocarbon-rich Paleozoic-Mesozoic passive-margin shelf. In Foreland Basins and Fold Belts (eds R. W. Macqueen \& D. A. Leckie), pp. 309-39. American Association of Petroleum Geologists Memoir no. 55.

BIRD, P. 1984. Laramide crustal thickening event in the Rocky Mountains foreland and Great Plains. Tectonics 3, 74158.

BIRD, P. 1988. Formation of the Rocky Mountains, western United States: a continuum computer model. Science 239, 1501-7.

Biteau, J.-J., Le Marrec, A., Le Vot, M. \& Masset, J.-M. 2006. The Aquitaine Basin. Petroleum Geoscience 12, 247-73.

Blanc, E. J.-P., Allen, M. B., Inger, S. \& Hassani, H. 2003. Structural styles in the Zagros Simple Folded Zone, Iran. Journal of the Geological Society, London 160, 3, 401-12.

Bonini, M., SANI, F. \& ANTONIELLI, B. 2012. Basin inversion and contractional reactivation of inherited normal faults: a review based on previous and new experimental models. Tectonophysics 522-523, 55-88.

Bonnet, C., Malavieille, J. \& Mosar, J. 2007. Interactions between tectonics, erosion, and sedimentation during the recent evolution of the Alpine orogen: analogue modeling insights. Tectonics 26, TC6016, doi: 10.1029/2006TC002048.

Boutoux, A., Bellahsen, N., Lacombe, O., Verlaguet, A. \& MouthereaU, F. 2014. Inversion of pre-orogenic extensional basins in the external Western Alps: structures, microstructures and restoration. Journal of Structural Geology 60, 13-29.

BROWN, W. G. 1988. Deformational style of Laramide uplifts in the Wyoming foreland. In Interaction of the Rocky Mountain Foreland and Cordilleran Thrust Belt (eds C. J. Schmidt \& W. J. Parry Jr), pp. 1-25. Geological Society of America Memoir no. 171.

Brown, D., Alvarez-Marron, J., Perez-Estaun, A., GoroZhaninA, Y., BARYSHEV, V. \& PUCHKOV, V. 1997. Geometric and kinematic evolution of the foreland thrust and fold belt in the southern Urals. Tectonics 16, 551-62.

Brown, D., Alvarez-Marron, J., Perez-Estaun, A., PuCHKOV, V. \& AYALA, C. 1999. Basement influence on 
foreland thrust-and-fold belt development: an example from the southern Urals, Tectonophysics 308, 459-72.

Brown, D., Alvarez-Marron, J., Schimmel, M., Wu, Y.M. \& CAMANNI, G. 2012. The structure and kinematics of the central Taiwan mountain belt derived from geological and seismicity data. Tectonics 31, TC5013, doi: 10.1029/2012TC003156.

BuMP, A. P. 2003. Reactivation, trishear modeling and folded basement in Laramide uplifts: implications for the origins of intracontinental faults. GSA Today March 2003, 4-10.

Burkhard, M. \& Sommaruga, A. 1998. Evolution of the western Swiss Molasse basin: structural relations with the Alps and the Jura belt. In Cenozoic Foreland Basins of Western Europe (eds A. Mascle, C. Puigdefabregas, H. P. Luterbacher \& M. Fernandez), pp. 279-98. Geological Society of London, Special Publication no. 134.

Butler, R. W. H., Holdsworth, R. E. \& Lloyd, G. E. 1997. The role of basement reactivation in continental deformation. Journal of the Geological Society, London 154, 69-72.

Butler, R. W. H., Mazzoli, S., Corrado, S., De Donatis, M., Di BuCCI, D., GAMBINI, R., NASO, G., NiCOlai, C., SCROCCA, D., SHINER, P. \& ZUCCONI, V. 2004. Applying thick-skinned tectonic models to the Apennine thrust belt of Italy-limitations and implications. In Thrust Tectonics and Hydrocarbon Systems (ed. K. R. McClay), pp. 647-67. American Association of Petroleum Geologists Memoir no. 82.

Butler, R. W. H., TAVARnelli, E. \& Grasso, M. 2006. Structural inheritance in mountain belts: an AlpineApennine perspective. Journal of Structural Geology 28, 1893-908.

Byrne, T., Chan, Y. C., Rau, R. J., Lu, C. Y., Lee, Y. H. \& WANG, Y. J. 2011. The arc-continent collision in Taiwan. In Arc-Continent Collision (eds D. Brown \& P. D. Ryan), pp. 213-45. Berlin: Springer.

CAHILL, T. \& ISACKS, B. 1992. Seismicity and shape of the subducted Nazca Plate. Journal of Geophysical Research 97, 17503-29.

Calamita, F., Coltorti, M., Piccinini, D., Pierantoni, P. P., Pizzi, A., Ripepe, M., Scisciani, V. \& Turco, E. 2000. Quaternary faults and seismicity in the UmbriaMarche Apennines (Central Italy): evidences from the 1997 Colfiorito earthquake. Journal of Geodynamics 29, 245-64.

Calamita, F., Pace, P. \& Satolli, S. 2012. Coexistence of fault-propagation and fault-bend folding in curveshaped foreland fold-and-thrust belts: examples from the Northern Apennines (Italy). Terra Nova 24, 396406.

Calamita, F., Satolli, S., Scisciani, V., Esestime, P. \& PACE, P. 2011. Contrasting styles of fault reactivation in curved orogenic belts: examples from the Central Apennines (Italy). Geological Society of America Bulletin 123, 1097-111.

Calkins, J. A., Zandt, G., Gilbert, H. J. \& BecK, S. L. 2006. Crustal images from San Juan, Argentina, obtained using high frequency local event receiver functions. Geophysical Research Letters 33, 7.

Camanni, G., Alvarez-Marron, J., Brown, D., Wu, Y.-M. \& HsieH, H.-H. 2015. The deep structure of south-central Taiwan illuminated by seismic tomography and earthquake hypocenter data. Tectonophysics, published online 30 September 2015. doi: 10.1016/j.tecto.2015.09.016.

Camanni, G., Brown, D., Alvarez-Marron, J., Wu, Y.M. \& CHEN, H.-A. 2014. The Shuilikeng fault in the central Taiwan mountain belt. Journal of the Geological Society, London 171, 117-30.

Carannante, S., Argnani, A., Massa, M., D’Alema, E., Lovati, S., Moretti, M., Cattaneo, M. \& Augliera, P. 2015. The May 20 (MW 6.1) and 29 (MW 6.0), 2012, Emilia (Po Plain, northern Italy) earthquakes: new seismotectonic implications from sub-surface geology and high-quality hypocenter location. Tectonophysics $\mathbf{6 5 5}$, 107-23.

Carena, S., Suppe, J. \& KaO, H. 2002. Active detachment of Taiwan illuminated by small earthquakes and its control of first-order topography. Geology 30, 935-8.

CARrera, N. \& MunOZ, J. A. 2013. Thick-skinned tectonic style resulting from inversion of previous structures in the Southern Cordillera Oriental (NW Argentine Andes). In Thick-Skin-Dominated Orogens: From Initial Inversion to Full Accretion (eds M. Nemcok, A. Mora \& J. Cosgrove), pp. 77-100. Geological Society of London, Special Publication no. 377.

Carrera, N., Muñoz, J. A., SÁbat, F., Mon, R. \& Roca, E. 2006. The role of inversion tectonics in the structure of the Cordillera Oriental (NW Argentinean Andes). Journal of Structural Geology 28, 1921-32.

CENKI-TOK, B., DARLing, J. R., Rolland, Y., DHuime, B. \& STOREY, C. D. 2013. Direct dating of mid-crustal shear zones with synkinematic allanite: new in situ $\mathrm{U}-\mathrm{Th}-\mathrm{Pb}$ geochronological approaches applied to the Mont Blanc massif. Terra Nova 26, 29-37.

Challandes, N., Marquer, D. \& Villa, I. M. 2008. P-T-t modelling, fluid circulation, and ${ }^{39} \mathrm{Ar}-{ }^{40} \mathrm{Ar}$ and $\mathrm{Rb}-\mathrm{Sr}$ mica ages in the Aar Massif shear zones (Swiss Alps). Swiss Journal of Geosciences 101, 269-88.

CHANG, S. S. L. \& CHI, W. R. 1983. Neogene nannoplankton biostratigraphy in Taiwan and the tectonic implications. Petroleum Geology of Taiwan 19, 93-147.

Chapple, W. M. 1978. Mechanics of thin-skinned fold-andthrust belts. Geological Society of America Bulletin 89, 1189-98.

Chase, R. B., Schmidt, C. J. \& Genovese, P. W. 1993. Influence of Precambrian rock compositions and fabrics on the development of Rocky Mountain foreland folds. In Laramide Basement Deformation in the Rocky Mountain Foreland of the Western United States (eds C. J. Schmidt, R. B. Chase \& E. A. Erslev), pp. 45-72. Geological Society of America Special Papers no. 280 .

Ching, K. E., Johnson, K. M., Rau, R. J., Chuang, R. Y., KUO, L. C. \& LEU, P. L. 2011. Inferred fault geometry and slip distribution of the 2010 Jiashian, Taiwan, earthquake is consistent with a thick-skinned deformation model. Earth and Planetary Science Letters 301, $78-86$.

CHIU, H. T. 1973. Basement rocks under the Neogene formation of west-central Taiwan. Proceedings of the Geological Society of China 16, 51-8.

ChuAnG, R. Y., Johnson, K. M., Wu, Y.-M., ChInG, K. \& KUO, L.-C. 2013. A mid-crustal ramp-fault structure beneath the Taiwan tectonic wedge illuminated by the 2013 Nantou earthquake series. Geophysical Research Letters 40, 5080-4.

Cisneros, H., Costa, C. \& GARDini, C. 2010. Neotectonic analysis of the Cerro Salinas area, Sarmiento department, province of San Juan. Revista de la Asociación Geológica Argentina 67, 439-49.

ClerC, C. \& LAGABRIELle, Y. 2014. Thermal control on the modes of crustal thinning leading to mantle exhumation: insights from the Cretaceous Pyrenean hot paleomargins. Tectonics 33, 1340-59. 
Cloetingh, S., Ziegler, P., Beekman, F., Andriessen, P., MATENCO, L., BADA, G., Garcia-CASTEllanos, D., HARDEBOL, N., DeZES, P. \& Sokoutis, D. 2005. Lithospheric memory, state of stress and rheology: neotectonic controls on Europe's intraplate continental topography. Quaternary Science Reviews 24, 241-304.

Collo, G., Davila, F., Nobile, J., Astini, R. A. \& GeHREls, G. 2011. Clay mineralogy and thermal history of the Neogene Vinchina Basin, central Andes of Argentina: analysis of factors controlling the heating conditions. Tectonics 30, TC4012, doi: 10.1029/2010TC002841.

COLMAN-SADD, S. 1978. Fold development in Zagros simply folded belt, Southwest Iran. American Association of Petroleum Geologists Bulletin 62, 984-1003.

COOPER, M. A. \& WARREN, M. J. 2010. The geometric characteristics, genesis and petroleum significance of inversion structures. In Continental Tectonics and Mountain Building: The Legacy of Peach and Horne (eds R. D. Law, R. W. H. Butler, R. E. Holdsworth, M. Krabbendam \& R. A. Strachan), pp. 827-46. Geological Society of London, Special Publication no. 335.

Corsini, M., RufFet, G. \& CABY, R. 2004. Alpine and lateHercynian geochronological constraints in the Argentera Massif (Western Alps). Eclogae Geologicae Helvetiae 97, 3-15.

Costa, C., Machette, M. N., Dart, R. L., Bastias, H. E., Paredes, J. D., Perucca, L. P., Tello, G. E. \& Haller, K. M. 2000. Map and Database of Quaternary Faults and Folds in Argentina. US Geological Survey Open File Report, OFR 00-0108, 81 pp., 1 map.

COWARD, M. P. 1994. Inversion tectonics. In Continental Deformation (ed. P. L. Hancock), pp. 289-304. Oxford: Pergamon Press.

Coward, M. P., De Donatis, M., Mazzoli, S., Paltrinieri, W. \& WEZEL, F.-C. 1999. Frontal part of the northern Apennines fold and thrust belt in the Romagna-Marche area (Italy): shallow and deep structural styles. Tectonics 18, 559-74.

Coward, M. P., Gillcrist, R. \& TRUdGill, B. 1991. Extensional structures and their tectonic inversion in the Western Alps. In The Geometry of Normal Faults (eds A. M. Roberts, G. Yielding \& B. Freeman), pp. 93-112. Geological Society of London, Special Publication no. 56.

CRISTALlini, E. O. \& RAMOS, V. A. 2000. Thick-skinned and thin-skinned thrusting in the La Ramada fold and thrust belt: crustal evolution of the High Andes of San Juan Argentina ( $\left.32^{\circ} \mathrm{SL}\right)$. Tectonophysics 317, 205-35.

Cross, T. A. 1986. Tectonic controls of foreland basin subsidence and Laramide style deformation, western United States. In Foreland Basins (eds P. A. Allen \& P. Homewood), pp. 15-39. International Association of Sedimentologists, Special Publication no. 8.

Crouzet, C., Menard, G. \& Rochette, P. 2001. Cooling history of the Dauphinoise zone (Western Alps, France) deduced from the thermopaleomagnetic record: geodynamic implications. Tectonophysics 340, 79-93.

Crowley, P. D., Reiners, P. W., Reuter, J. M. \& Kaye, G. D. 2002. Laramide exhumation of the Bighorn Mountains, Wyoming: an apatite (U-Th)/He thermochronology study. Geology 30, 27-30.

Dahlen, F. A., SupPE, J. \& DaVIS, D. 1984. Mechanics of fold-and-thrust belts and accretionary wedges: a cohesive Coulomb theory. Journal of Geophysical Research 89, 10087-101.

DAVILA, F. M. \& CARTER, A. 2013. Exhumation and history of the Andean broken foreland revisited. Geology 41, $443-6$.
DAVIS, D. \& ENGELDER, T. 1985. Role of salt in fold-andthrust belts. Tectonophysics 119, 67-88.

Davis, S. J., Mulch, A., Carroll, A. R., Horton, T. W. \& Chamberlain, C. P. 2009. Paleogene landscape evolution of the central North American Cordillera: developing topography and hydrology in the Laramide foreland. Geological Society of America Bulletin 121, $100-16$.

DAVIS, D., SuPPE, J. \& DAHLEN, F. A. 1983. Mechanisms of fold-and-thrust belts and accretionary wedges. Journal of Geophysical Research 88, 1153-72.

DeCelles, P. G. \& Giles, K. A. 1996. Foreland basin systems. Basin Research 8, 105-23.

DeCelles, P. G., Gray, M. B., Ridghay, K. D., Cole, R. B., Srivastava, P., Pequera, N. \& Pivnik, D. A. 1991. Kinematic history of a foreland uplift from Paleocene synorogenic conglomerate, Beartooth Range, Wyoming and Montana. Geological Society of America Bulletin 103, 1458-75.

DeCelles, P. G., Tolson, R. B., Graham, S. A., Smith, G. A., Ingersoll, R. V., White, J., Schmidt, C. J., Rice, R., Moxon, I., Lemke, L., Handschy, J. W., Follo, M. F., EdWARdS, D. P., CAVAZZA, W., CAldWell, M. \& BARGAR, E. 1987. Laramide thrust-generated alluvialfan sedimentation: Sphinx Conglomerate, southwestern Montana. American Association of Petroleum Geologists Bulletin 71, 135-55.

Dechesne, R. G. \& Mountjoy, E. W. 1992. Multiple thrust detachment at deep levels of the southern Canadian Rocky Mountain Main Range, Alberta and British Columbia. In Structural Geology of Fold and Thrust Belts (eds S. Mitra \& G. W. Fisher), pp. 225-38. Baltimore: John Hopkins University Press.

Deffontaines, B., Lacombe, O., Angelier, J., Chu, H.T., Mouthereau, F., Lee, C.-T., Deramond, J., LeE, J.-F., YU, M.-S. \& LIEW, P.-M. 1997. Quaternary transfer faulting in Taiwan Foothills: evidence from a multisource approach. Tectonophysics 274, 61-82.

Deville, E., Mascle, A., Lamiraux, C. \& Le Bras, A. 1994. Tectonic styles, reevaluation of plays in southeastern France. Oil Gas Journal 31, 53-8.

DICKINSON, W. R. 1976. Sedimentary basins developed during evolution of Mesozoic Cenozoic arc-trench system in western North America. Canadian Journal of Earth Sciences 13, 1268-87.

Dickinson, W. R., Klute, M. A., HaYes, M. J., JanecKe, S. U., Lundin, E. R., MCKITTRICK, M. A. \& Olivares, M. D. 1988. Paleogeographic and paleotectonic setting of Laramide sedimentary basins in the central Rocky Mountain region. Geological Society of America Bulletin 100, 1023-39.

DiCKINSON, W. R. \& SNYDER, W. S. 1978. Plate tectonics of the Laramide orogeny. In Laramide Folding Associated with Basement Block Faulting in the Western United States (ed. V. Matthews), pp. 355-66. Geological Society of America Memoir no. 151.

Duchene, S., Blichert-Toft, J., Luais, B., Telouk, P., LARDEAUX, J. M. \& AlBAREDE, F. 1997. The Lu-Hf dating of garnets and the ages of the Alpine high-pressure metamorphism. Nature 387, 586-9.

Dumont, T., Champagnac, J. D., Crouzet, C. \& Rochat, P. 2008. Multistage shortening in the Dauphiné zone (French Alps): the record of Alpine collision and implications for pre-Alpine restoration. Swiss Journal of Geosciences 101, 89-110.

EdGELL, H. S. 1992. Basement tectonics of Saudi Arabia as related to oil field structures. In Basement Tectonics 9 (eds M. J. Rickard, H. J. Harrington \& P. R. Williams), 
pp. 169-93. Proceedings of the International Conferences on Basement Tectonics no. 3. Dordrecht: Springer.

EdGell, H. S. 1996. Salt tectonism in the Persian Gulf Basin. In Salt Tectonics (eds G. I. Alsop, D. J. Blundell \& I. Davison), pp. 129-51. Geological Society of London, Special Publication no.100.

EGAN, S. \& URQUHART, J. 1993. Numerical modelling of lithosphere shortening: application to the Laramide orogenic province, western USA. Tectonophysics 221, 385411.

Emami, H., Vergés, J., Nalpas, T., Gillespie, P., Sharp, I., Karpuz, R., Blanc, E. P. \& GoOdARZI, M. G. H. 2010. Structure of the Mountain Front Flexure along the Anaran anticline in the Pusht-e Kuh Arc (NW Zagros, Iran): insights from sand box models. In Tectonic and Stratigraphic Evolution of Zagros and Makran During the Mesozoic-Cenozoic (eds P. Leturmy \& C. Robin), pp. 155-78. Geological Society of London, Special Publication no. 330 .

ENGLish, J. M., Johnston, S. T. \& WANG, K. 2003. Thermal modeling of the Laramide Orogeny; testing the flatslab subduction hypothesis. Earth and Planetary Science Letters 214, 619-32.

ERdos, Z., Huismans, R. S. \& VAN DER BEeK, P. 2015. Firstorder control of syntectonic sedimentation on crustalscale structure of mountain belts. Journal of Geophysical Research 120, 5362-77.

ERNST, W. G. 2010. Young convergent-margin orogens, climate, and crustal thickness - A Late Cretaceous- Paleogene Nevadaplano in the American Southwest? Lithosphere 2, 67-75.

ERSLEV, E. A. 1991, Trishear fault-propagation folding. Geo$\log y$ 19, 617-20.

ERSLEV, E. A. 1986. Basement balancing of Rocky Mountain foreland uplifts. Geology 14, 259-62.

ERSLEV, E. A. 1993, Thrusts, back-thrusts, and detachment of Rocky Mountain foreland arches. In Laramide Basement Deformation in the Rocky Mountain Foreland of the Western United States (eds C. J. Schmidt, R. B. Chase \& E. A. Erslev), pp. 339-59. Geological Society of America Special Papers no. 280.

ERSLEV, E. A. 2005. 2D Laramide geometries and kinematics of the Rocky Mountains, western USA. In The Rocky Mountain Region: An Evolving Lithosphere. Tectonics, Geochemistry, and Geophysics (eds K. E. Kalstrom \& G. R. Keller), pp. 7-20. American Geophysical Union, Geophysical Monograph Series vol. 154. Washington, DC, USA.

ERslev, E. A. \& Rogers, J. L. 1993. Basement-cover geometry of Laramide fault-propagation folds. In Laramide Basement Deformation in the Rocky Mountain Foreland of the Western United States (eds C. J. Schmidt, R. B. Chase \& E. A. Erslev), pp. 125 46. Geological Society of America Special Papers no. 280 .

Espurt, N., Funiciello, F., Martinod, J., Guillaume, B., Regard, V., Faccenna, C. \& Brusset, S. 2008. Flat subduction and deformation of the South American plate: insights from analog modeling. Tectonics 27, TC3011, doi: 10.1029/2007TC002175.

Espurt, N., HiPPOlyte, J.-C., SAillard, M. \& Bellier, O. 2012. Geometry and kinematic evolution of a long-living foreland structure inferred from field data and cross section balancing, the Sainte-Victoire system, Provence, France. Tectonics 31, TC4021, doi: 10.1029/2011TC002988.

FACCENDA, M., Gerya, T. V. \& ChaKraborty, S. 2008. Styles of post-subduction collisional orogeny: influence of convergence velocity, crustal rheology and radiogenic heat production. Lithos 103, 257-87.

FAN, M. \& CARRAPA, B. 2014. Late Cretaceous-early Eocene Laramide uplift, exhumation, and basin subsidence in Wyoming: crustal responses to flat slab subduction. Tectonics 33, 509-29.

Fernandez, O., Munoz, J., Arbues, P. \& Falivene, O. 2012. 3D structure and evolution of an oblique system of relaying folds: the Ainsa basin (Spanish Pyrenees). Journal of the Geological Society, London 169, 545-59.

FIELDING, E. J. \& JoRdAN, T. E. 1988. Active deformation at the boundary between the Precordillera and the Sierras Pampeanas, Argentina and comparison with ancient Rocky Mountain deformation. In Interaction of the Rocky Mountain Foreland and the Cordilleran Thrust Belt (eds C. J. Schmidt \& W. J. Perry), pp. 143-63. Geological Society of America Memoir no. 171.

Finetti, I., Boccaletti, M., Bonini, M., Delben, A., Geletti, R., Pipan, M. \& SANI, F. 2001. Crustal section based on CROP seismic data across the north Tyrrhenian-Northern Apennines-Adriatic Sea. Tectonophysics 343, 135-63.

Fitzgerald, P. G., MuÑoz, J. A., Coney, P. J. \& BALdwin, S. L. 1999. Asymmetric exhumation across the Pyrenean orogen: implications for the tectonic evolution of a collisional orogeny. Earth and Planetary Science Letters 173, 157-70.

FORD, M. 1996. Kinematics and geometry of early Alpine, basement involved folds, SW Pelvoux Massif, SE France. Eclogae Geologicae Helvetiae 89, 269-95.

GARCIA, P. E. \& DAVIS, G. H. 2004. Evidence and mechanisms for folding of granite, Sierra de Hualfin basementcored uplift, northwest Argentina. American Association of Petroleum Geologists Bulletin 88, 1255-76.

Garcia-SenZ, J., MuÑOZ, J. A. \& MCClay, K. 2000. Inversion of Early Cretaceous extensional basins in the central Spanish Pyrenees. American Association of Petroleum Geologists Bulletin 84, 1428-29.

Giamboni, M., UstaszewsKi, K., Schmid, S. M., Schumacher, M. E. \& WeTZEL, A. 2004. PlioPleistocene transpressional reactivation of Paleozoic and Paleogene structures in the Rhine-Bresse transform zone (northern Switzerland and eastern France). International Journal of Earth Sciences 93, 207-23.

Gibson, M., Sinclair, H. D., LynN, G. J. \& StuART, F. M. 2007. Late- to post-orogenic exhumation of the central Pyrenees revealed through combined thermochronological data and modelling. Basin Research 19, 323-34.

GIDON, M. 1999. L'origine des abrupts septentrionaux du Taillefer, massifs cristallins externes, Isère, France. Géologie Alpine 75, 103-9.

Gillcrist, R., COWARD, M. \& Mugnier, J. L. 1987. Structural inversion and its controls - examples from the Alpine foreland and the French Alps. Geodinamica Acta 1, 5-34.

Gourley, J. R., Byrne, T., Chan, Y.-C., Wu, F. \& RaU, R.J. 2007. Fault geometries illuminated from seismicity in central Taiwan: implications for crustal scale structural boundaries in the northern Central Range. Tectonophysics 445, 168-85.

Gutscher, M. A., SPAKMAN, W., BiJWAARD, H. \& ENGDAhL, E. 2000. Geodynamics of flat subduction: seismicity and tomographic constraints from the Andean margin. Tectonics 19, 814-33.

Hagen, E. S., Shuster, M. W. \& Furlong, K. P. 1985. Tectonic loading and subsidence of intermontane basins: Wyoming foreland province. Geology 13, 585-8. 
Hain, M. P., Strecker, M. R., Bookhagen, B., Alonso, R. N., PINGel, H. \& SCHMITT, A. K. 2011. Neogene to Quaternary broken foreland formation and sedimentation dynamics in the Andes of NW Argentina $\left(25^{\circ} \mathrm{S}\right)$. Tectonics 30, TC2006, doi: 10.1029/2010TC002703.

Haines, P. W., HAND, M. \& SANDiFORD, M. 2001. Palaeozoic synorogenic sedimentation in central and northern Australia: a review of distribution and timing with implications for the evolution of intracontinental orogens. Australian Journal of Earth Sciences 48, 911-28.

HAMILTON, W. B. 1988. Laramide crustal shortening. In Interaction of the Rocky Mountain Foreland and the Cordilleran Thrust Belt (eds C. J. Schmidt \& W. J. Perry), pp. 27-39. Geological Society of America Memoir no. 171.

Hermeston, S. \& NemCoK, M. 2013. Thick-skin orogenforeland interactions and their controlling factors, Northern Andes of Colombia. In Thick-Skin-Dominated Orogens: From Initial Inversion to Full Accretion (eds M. Nemcok, A. Mora \& J. Cosgrove), pp. 443-71. Geological Society of London, Special Publication no. 377.

Hessami, K., Koyi, H. A., Talbot, C. J., Tabasi, H. \& Shabanian, E. 2001. Progressive unconformities within an evolving foreland fold-thrust belt, Zagros Mountains. Journal of the Geological Society, London 158, 969-81.

HiLl, K. C. \& HAYWARD, A. B. 1988. Structural constraints on the Tertiary plate tectonic evolution of Italy. Marine and Petroleum Geology 5, 2-16.

Ho, C. S. 1986. A synthesis of the geologic evolution of Taiwan. Tectonophysics 125, 1-16.

HofmanN, B. A., Helfer, M., Diamond, L. W., Villa, I. M., FREI, R. \& EIKENBERG, J. 2004. Topography-driven hydrothermal breccia mineralization of Pliocene age at Grimsel Pass, Aar massif, Central Swiss Alps. Schweizerische Mineralogische und Petrographische Mitteilungen 84, 271-302.

Holbrook, W. S., Mooney, W. D. \& Christensen, N. I. 1992. The seismic velocity structure of the deep continental crust. In Continental Lower Crust, pp. 1-43. Amsterdam: Elsevier.

Holdsworth, J. A., Buick, R. E. \& HAND, M. (eds) 2001. Continental Reactivation and Reworking. Geological Society of London, Special Publication no. 184, 408 $\mathrm{pp}$.

Homke, S., Verges, J., Serra-Kiel, J., Bernaola, G., Sharp, I., GARCES, M., Montero-Verdu, I., KARPUZ, R. \& GoOdARZI, M. H. 2009. Late CretaceousPaleocene formation of the proto-Zagros foreland basin, Lorestan Province, SW Iran. Geological Society of America Bulletin 121, 963-78.

HoY, R. G. \& RIDGWAY, K. D. 1997. Structural and sedimentological development of footwall growth synclines along an intraforeland uplift, east-central Bighorn Mountains, Wyoming. Geological Society of America Bulletin 109, 915-35.

Huang, S. T., CHEN, R. C. \& ChI, W. R. 1993. Inversion tectonics and evolution of the northern Taihsi Basin, Taiwan. Petroleum Geology of Taiwan 28, 15-46.

Huang, M. H., Dreger, D., Bürgmann, R., Yoo, S. H. \& HASHIMOTO, M. 2013. Joint inversion of seismic and geodetic data for the source of the 2010 March 4, Mw 6.3 Jia-Shian, SW Taiwan, earthquake. Geophysical Journal International 193, 1608-26.

Humphreys, E., Hessler, E., DueKer, K., Farmer, G. L., ERSLEV, E. \& ATWATER, T. 2003. How Laramide-age hydration of North American lithosphere by the Farallon slab controlled subsequent activity in the western United States. International Geology Review 45, 575-95.

Hung, J.-H., WiltschKo, D. V., Lin, H.-C., Hickman, J. B., FANG, P. \& BOCK, Y. 1999. Structure and motion of the southwestern Taiwan fold and thrust belt. Terrestrial, Atmospheric and Oceanic Sciences 10, 543-68.

HussEINI, M. I. 1988. The Arabian lnfracambrian extensional system. Tectonophysics 148, 93-103.

Hwang, C., HsiaO, Y.-S., SHIH, H.-C., YANG, M., ChEN, K.-H., ForsberG, R. \& Olesen, A. V. 2007. Geodetic and geophysical results from a Taiwan airborne gravity survey: data reduction and accuracy assessment. Journal of Geophysical Research 112, B04407, doi: 10.1029/2005JB004220.

IAFFA, D. N., SABAT, F., MunOZ, J. A. \& CARRERA, N. 2013. Basin fragmentation controlled by tectonic inversion and basement uplift in Sierras Pampeanas and Santa Bárbara System, Northwest Argentina. In Thick-Skin-Dominated Orogens: From Initial Inversion to Full Accretion (eds M. Nemcok, A. Mora \& J. W. Cosgrove), pp. 101-17. Geological Society of London, Special Publication no. 377.

ImBer, J., Holdsworth, R. E., Butler, C. A. \& Lloyd, G. E. 1997. Fault-zone weakening processes along the reactivated Outer Hebrides Fault Zone, Scotland. Journal of the Geological Society, London 154, 105-9.

IMBER, J., HOLDSWORTH, R. E., BUTLER, C. A. \& StRACHAN, R. A. 2001. A reappraisal of the Sibson-Scholz fault zone model: the nature of the frictional to viscous ("brittle-ductile") transition along a long-lived, crustalscale fault, Outer Hebrides, Scotland. Tectonics 20, 60124.

JACKSON, J. 1980. Reactivation of basement faults and crustal shortening in orogenic belt. Nature 283, 561-86.

JACKSON, J. \& MCKENZIE, D. 1984. Active tectonics of the Alpine-Himalayan Belt between western Turkey and Pakistan. Geophysical Journal of the Royal Astronomical Society 77, 185-264.

JAMmeS, S. \& Huismans, R. S. 2012. Structural styles of mountain building: controls of lithospheric rheologic stratification and extensional inheritance. Journal of Geophysical Research 117, B10403, doi: 10.1029/2012JB009376.

Jammes, S., Manatschal, G., LaVier, L. \& Masini, E. 2009. Tectono-sedimentary evolution related to extreme crustal thinning ahead of a propagating ocean: example of the western Pyrenees. Tectonics 28, TC4012, doi: $10.1029 / 2008$ TC002406.

Jolivet, M., LABAUMe, P., Monie, P., BRUnel, M., ARNAUd, N. \& CAMPANI, M. 2007. Thermochronology constraints for the propagation sequence of the south Pyrenean basement thrust system (France-Spain). Tectonics 26, TC5007, doi: 10.1029/2006TC002080.

Jones, C. H., Farmer, G. L., Sageman, B. \& Zhong, S. 2011. Hydrodynamic mechanism for the Laramide orogeny. Geosphere 7, 183-201.

JordAn, T. E. \& ALLMENDINGER, R. W. 1986. The Sierras Pampeanas of Argentina: a modern analogue of Rocky Mountain foreland deformation. American Journal of Science 286, 737-64.

Jordan, T. E., IsACKS, B. L., Allmendinger, R. W., BREWER, J. A., RAMOS, V. A. \& ANDO, C. J. 1983. Andean tectonics related to geometry of subducted Nazca plate. Geological Society of America Bulletin 94, 34161.

JULliEN, M. \& GoFFÉ, B. 1993. Cookeite and pyrophyllite in the Dauphinois black shales (Isère, France): implications for the conditions of metamorphism in the Alpine 
external zones. Schweizerische Mineralogische und Petrographische Mitteilungen 73, 257-363.

KADINSKY-CADE, K., REILINGER, R. \& ISACKS, B. 1985. Surface deformation associated with the November 23, 1977, Caucete, Argentina, earthquake sequence. Journal of Geophysical Research 90, 12691-700.

KAY, S. M. \& ABBRUZZI, J. M. 1996. Magmatic evidence for Neogene lithospheric evolution of the central Andean "flat-slab" between $30^{\circ} \mathrm{S}$ and $32^{\circ} \mathrm{S}$. Tectonophysics $\mathbf{2 5 9}$, $15-28$.

Kley, J. \& Monaldi, C. R. 2002. Tectonic inversion in the Santa Barbara System of the central Andean foreland thrust belt, northwestern Argentina. Tectonics 21, 1061, doi: 10.1029/2002TC902003.

Kober, M., Seib, N., Kley, J. \& Voigt, T. 2013. Thickskinned thrusting in the northern Tien Shan foreland, Kazakhstan: Structural inheritance and polyphase deformation. In Thick-Skin-Dominated Orogens: From Initial Inversion to Full Accretion (eds M. Nemcok, A. Mora \& J. W. Cosgrove), pp. 19-42. Geological Society, London, Special Publications no. 377.

Koop, W. \& Stoneley, R. 1982. Subsidence history of the middle East Zagros basin, Permian to Recent. Philosophical Transactions of the Royal Society of London 305, 149-68.

Kralik, M., Clauer, N., Holnsteiner, R., Huemer, H. \& KAPPEL, F. 1992. Recurrent fault activity in the Grimsel Test Site (GTS, Switzerland) revealed by $\mathrm{Rb}-\mathrm{Sr}, \mathrm{K}-\mathrm{Ar}$ and tritium isotope techniques. Journal of the Geological Society, London 149, 293-301.

LABAume, P., Seguret, M. \& Seyve, C. 1985. Evolution of a turbiditic foreland basin and analogy with an accretionary prism - example of the Eocene South-Pyrenean basin. Tectonics 4, 661-85.

LACOMBE, O. \& MouthereaU, F. 1999. What is the real front of orogens? The Pyrenean orogen as a case study. Comptes Rendus Académie Sciences Paris 329, 889-96.

LACOMBE, O. \& MOUTHEREAU, F. 2002. Basement-involved shortening and deep detachment tectonics in forelands of orogens: insights from recent collision belts (Taiwan, western Alps, Pyrenees). Tectonics 21, 1030, doi: 10.1029/2001TC901018.

Lacombe, O., Mouthereau, F., Angelier, J., Chu, H. T. \& LEE, J. C. 2003, Frontal belt curvature and oblique ramp development at an obliquely collided irregular margin: geometry and kinematics of the NW Taiwan fold-thrust belt. Tectonics 22, 1025, doi: 10.1029/2002TC001436.

Lacombe, O., Mouthereau, F., Angelier, J. \& DeFFOnTAINES, B. 2001. Structural, geodetic and seismological evidence for tectonic escape in SW Taiwan. Tectonophysics 333, 323-45.

Lacombe, O., Mouthereau, F., DefFontaines, B., ANGELIER, J., ChU, H.-T. \& LEE, C. T. 1999. Geometry and Quaternary kinematics of fold-and-thrust units of SW Taiwan. Tectonics 18, 1198-223.

Lagabrielle, Y., Labaume, P. \& De Saint Blanquat, M. 2010. Mantle exhumation, crustal denudation, and gravity tectonics during Cretaceous rifting in the Pyrenean realm (SW Europe): insights from the geological setting of the lherzolite bodies. Tectonics 29, TC4012, doi: 10.1029/2009TC002588.

LANGER, C. \& BOLLINGER, G. 1988. Aftershocks of the western Argentina (Caucete) earthquake of 23 November 1977: some tectonic implications. Tectonophysics 148 , 131-46.

LeE, C. I., Chang, Y. L. \& CowarD, M. P. 2002. Inversion tectonics of the fold-and-thrust belt, Western Taiwan. In Geology and Geophysics of an Arc-Continent Col- lision, Taiwan, Republic of China (eds T. B. Byrne \& C.-S. Liu), pp. 13-30. Geological Society of America Special Papers no. 358.

Lee, C.-I., Chang, Y.-L., MaO, E.-W. \& Tseng, C.-S. 1993. Fault reactivation and structural inversion in the Hsinchu-Miaoli area of northern Taiwan. Petroleum Geology of Taiwan 28, 47-58.

Leloup, P., Arnaud, N., Sobel, E. \& Lacassin, R. 2005. Alpine thermal and structural evolution of the highest external crystalline massif: the Mont Blanc. Tectonics 24, TC4002, doi: 10.1029/2004TC001676.

LETOUZEY, J. 1990. Fault reactivation, inversion and foldthrust belts. In Petroleum and Tectonics in Mobile Belts (ed. J. Letouzey), pp. 101-28. Paris: Editions Technip.

Lin, K.-C., Delouis, B., Hu, J.-C., NocQueT, J.-M. \& MOZZICONACCI, L. 2015. Reassessing the complexity of the rupture of the 2010 Jia-Shian Earthquake (Mw 6.2) in Southwestern Taiwan by inverting jointly teleseismic, strong motion and CGPS data. Tectonophysics, published online 28 September 2015. doi: 10.1016/j.tecto.2015.09.015.

Liu, L., Gurnis, M., Seton, M., Slaeeby, J., Muller, R. D. \& JACKSON, J. M. 2010. The role of oceanic plateau subduction in the Laramide orogeny. Nature Geoscience 3, 353-7.

LIVACCARI, R. F. 1991. Role of crustal thickening and extensional collapse in the tectonic evolution of the SevierLaramide orogeny, western United States. Geology 19, 1104-7.

Livaccari, R. F., Burke, K. \& ŞEngöR, A. M. C. 1981. Was the Laramide orogeny related to subduction of an oceanic plateau? Nature 289, 276-8.

LU, C.-Y., JeNG, F.-S., CHANG, K.-J. \& JiAN, W.-T. 1998. Impact of basement high on the structure and kinematics of the western Taiwan thrust wedge: insights from sandbox models. Terrestrial Atmospheric Oceanic Sciences 9, 533-50.

LYNN, H. B., QuAM, S. \& THOMPSON, G. A. 1983. Depth migration and interpretation of the COCORP Wind River, Wyoming, seismic reflection data. Geology 11, 462-9.

MADRITSCH, H., SCHMID, S. M. \& FABBRI, O. 2008 Interactions between thin- and thick-skinned tectonics at the northwestern front of the Jura fold-andthrust belt (eastern France). Tectonics 27, TC5005, doi: 10.1029/2008TC002282.

MarshaK, S., Karlstrom, K. \& Timmons, J. M. 2000. Inversion of Proterozoic extensional faults: an explanation for the pattern of Laramide and Ancestral Rockies intracratonic deformation, United States. Geology 28, 735-8.

Mattioni, L., Sassi, W. \& Callot, J.-P. 2007. Analogue models of basin inversion transpression: role of structural heterogeneity. In Deformation of the Continental Crust: The Legacy of Mike Coward (eds A. C. Ries, R. W. H. Butler \& R. H. Graham), pp. 397 417. Geological Society of London, Special Publication no. 272.

MCQUARRIE, N. 2004. Crustal scale geometry of the Zagros fold-thrust belt, Iran. Journal of Structural Geology 26, 519-35.

Meigs, A., Krugh, W. C., Schiffman, C., Vergés, J. \& RAMOS, V. A. 2006. Refolding of thin-skinned thrust sheets by active basement-involved thrust faults in the Eastern Precordillera of western Argentina. Revista de la Asociación Geológica Argentina 61, 589-603.

Mescua, J. F., Giambiagi, L. B., TAsSARA, A., Gimenez, M. \& RAMOS, V. A. 2014. Influence of pre-Andean history over Cenozoic foreland deformation: Structural styles 
in the Malargüe fold-and-thrust belt at $35^{\circ} \mathrm{S}$, Andes of Argentina. Geosphere 10, 585-609.

Meyer, B., Lacassin, R., Brulhet, J. \& Mouroux, B. 1994. The Basel 1356 earthquake: which fault produced it? Terra Nova 6, 54-63.

MiraBella, F., BARCHI, M. R. \& LUPATTELLI, A. 2008. Seismic reflection data in the Umbria Marche Region: limits and capabilities to unravel the sub-surface structure in a seismically active area. Annals of Geophysics 51, doi: 10.4401/ag-3032.

MitRA, G. \& FrOST, B. R. 1981. Mechanisms of deformation within Laramide and Precambrian deformation zones in basement rocks of the Wind River Mountains. Contribution to Geology 19, 161-73.

MitRA, S. \& MOUNT, V. S. 1998. Foreland basement-involved structures. American Association of Petroleum Geologists Bulletin 82, 70-109.

Mohn, G., Manatschal, G., Masini, E. \& Muntener, O. 2011. Rift-related inheritance in orogens: a case study from the Austroalpine nappes in Central Alps (SESwitzerland and N-Italy). International Journal of Earth Sciences (Geologische Rundschau) 100, 927-61.

Molinaro, M., Leturmy, P., Guezou, J. C., Frizon De LAmotTe, D. \& Eshraghi, S. A. 2005. The structure and kinematics of the southeastern Zagros fold-thrust belt, Iran: from thin-skinned to thick-skinned tectonics. Tectonics 24, TC3007, doi: 10.1029/2004TC001633.

Mora, A., Gaona, T., Kley, J., Montoya, D., Parra, M., Quiroz, L. I., Reyes, G. \& Strecker, M. R. 2009. The role of inherited extensional fault segmentation and linkage in contractional orogenesis: a reconstruction of Lower Cretaceous inverted rift basins in the Eastern Cordillera of Colombia. Basin Research 21, 111-37.

Mora, A., Horton, B., Mesa, A., Rubiano, J., Ketcham, R. A., PARra, M., Blanco, V., Garcia, D. \& Stockli, D. F. 2010. Migration of Cenozoic deformation in the Eastern Cordillera of Colombia interpreted from fission track results and structural relationships: implications for hydrocarbon systems. American Association of Petroleum Geologists Bulletin 94, 1543-80.

Mora, A., Parra, M., Strecker, M. R., Kammer, A., Dimate, C. \& Rodriguez, F. 2006. Cenozoic contractional reactivation of Mesozoic extensional structures in the Eastern Cordillera of Colombia. Tectonics 25, TC2010, doi: 10.1029/2005TC001854.

Mora, A., Parra, M., Strecker, M., Sobel, E. R., Hooghiemstra, H., Torres, V. \& Jaramillo, J. V. 2008. Climatic forcing of asymmetric orogenic evolution in the Eastern Cordillera of Colombia. Geological Society of America Bulletin 120, 930-49.

Morley, C. K., Kongwung, B., Julapour, A. A., Abdolghafourian, M., HaJian, M., Waples, D., WARren, J., OtTERdoOM, H., SRISURIYON, K. \& KAZEMI, H. 2009. Structural development of a major late Cenozoic basin and transpressional belt in central Iran: the Central Basin in the Qom-Saveh area. Geosphere 5, 325-62.

MorRis, R. G., Sinclair, H. D. \& Yelland, A. J. 1998. Exhumation of the Pyrenean orogen: implications for sediment discharge. Basin Research 10, 69-85.

MosAR, J. 1999. Present-day and future underplating in the western Swiss Alps: reconciliation of basement/wrenchfaulting and thrust detachment folding of the Jura and Molasse basin in the Alpine foreland. Earth Planetary Science Letters 173, 143-55.

Mouthereau, F., Deffontaines, B., Lacombe, O. \& ANGELIER, J. 2002. Variations along the strike of the Taiwan thrust belt: basement control on structural style, wedge geometry and kinematics. In Geology and Geophysics of an Arc-Continent Collision, Taiwan, Republic of China (eds T. B. Byrne \& C.-S. Liu), pp. 35-58. Geological Society of America Special Papers no. 358.

Mouthereau, F., Filleaudeau, P.-Y., Vacherat, A., Pik, R, Lacombe, O., Fellin, M. G., Castelltort, S., Christophoul, F. \& Masini, E. 2014. Placing limits to shortening evolution in the Pyrenees: role of margin architecture and implications for the Iberia/Europe convergence. Tectonics 33, 2283-314.

MouthereAU, F. \& LACOMBE, O. 2006, Inversion of the Paleogene Chinese continental margin and thick-skinned deformation in the western foreland of Taiwan. Journal of Structural Geology 28, 1977-93.

Mouthereau, F., Lacombe, O., DefFontaines, B., ANGelieR, J., CHU, H.-T. \& LEE, C.-T. 1999. Quaternary transfer faulting and belt front deformation at Pakuashan (western Taiwan). Tectonics 18, 215-30.

Mouthereau, F., Lacombe, O. \& Meyer, B. 2006. The Zagros Folded Belt (Fars, Iran): constraints from topography and critical wedge modelling. Geophysical Journal International 165, 336-56.

Mouthereau, F., LACOMBE, O. \& Verges, J. 2012. Building the Zagros collisional orogen: timing, strain distribution and the dynamics of Arabia/Eurasia plate convergence. Tectonophysics 532-535, 27-60.

Mouthereau, F. \& Petit, C. 2003. Rheology and strength of the Eurasian continental lithosphere in the foreland of the Taiwan collision belt: constraints from seismicity, flexure, and structural styles. Journal of Geophysical Research 108, 2512.

Mouthereau, F., Tensi, J., Bellahsen, N., Lacombe, O., Deboisgrollier, T. \& KARGAR, S. 2007. Tertiary sequence of deformation in a thin-skinned/thick-skinned collision belt: the Zagros Folded Belt (Fars, Iran). Tectonics 26, TC5006, doi: 10.1029/2007TC002098.

Mouthereau, F., WatTS, A. B. \& Burov, E. 2013. Structure of orogenic belts controlled by lithosphere age. Nature Geoscience 6, 785-9.

NAMSON, J. 1981. Structure of the Western Foothills Belt, Miaoli-Hsinchu area, Taiwan: (I) Southern part. Petroleum Geology of Taiwan 18, 31-51.

NAMSON, J. 1984. Detailed structural analysis of the western foothills belt in the Miaoli-Hsinchu area, Taiwan, III, Northern part. Petroleum Geology of Taiwan 20, 35-52.

NARR, W. 1993. Deformation of basement in basementinvolved compressive structures. In Laramide Basement Deformation in the Rocky Mountain Foreland of the Western United States (eds C. J. Schmidt, R. B. Chase \& E. A. Erslev), pp. 107-24. Geological Society of America Special Papers no. 280.

NARR, W. \& SUPPE, J. 1994. Kinematics of basementinvolved compressive structures. American Journal of Science 294, 802-60.

NeELy, T. G. \& ERSLEV, E. A. 2009. The interplay of fold mechanisms and basement weaknesses at the transition between Laramide basement-involved arches, northcentral Wyoming, USA. Journal of Structural Geology 31, 1012-27.

NemcoK, M., Glonti, B., Yukler, A. \& Marton, B. 2013. Development history of the foreland plate trapped between two converging orogens; Kura Valley, Georgia, case study. In Thick-Skin-Dominated Orogens: From Initial Inversion to Full Accretion (eds M. Nemcok, A. Mora \& J. W. Cosgrove), pp. 159-88. Geological Society of London, Special Publication no. 377.

NemcoK, M., KrZYwiec, P., WoJtaszeK, M., Ludhova, L., Klecker, R. A., Sercombe, W. J. \& Coward, 
M. P. 2006. Tertiary development of the Polish and Eastern Slovakian parts of the Carpathian accretionary wedge: insights from balanced cross sections. Geologica Carpathica 57, 355-70.

NemcoK, M., MorA, A. \& Cosgrove, J. W. 2013. Thickskin-dominated orogens; from initial inversion to full accretion: an introduction. In Thick-Skin-Dominated Orogens: From Initial Inversion to Full Accretion (eds M. Nemcok, A. Mora \& J. Cosgrove), pp. 1-17. Geological Society of London, Special Publication no. 377.

NEMCOK, M., SCHAMEL, S. \& GAYER, R. A. 2005. Thrust Belts: Structural Architecture, Thermal Regimes and Petroleum Systems. Cambridge: Cambridge University Press.

Nilfouroushan, F., Pysklywec, R., Cruden, A. \& Koyi, H. 2013. Thermal-mechanical modeling of salt-based mountain belts with pre-existing basement faults: application to the Zagros fold and thrust belt, southwest Iran. Tectonics 32, 1212-26.

Nissen, E., Tatar, M., Jackson, J. A. \& Allen, M. B. 2011. New views on earthquake faulting in the Zagros fold-and-thrust belt of Iran. Geophysical Journal International 186, 928-44.

Oberhänsli, R., Bousquet, R., Engi, M., Goffé, B., Gosso, G., Handy, M., Höck, V., Koller, F., Lardeaux, J.-M., Polino, R., Rossi, P., Schuster, R., SCHWARTZ, S \& SPALlA, I. 2004. Map of the Metamorphic Structure of the Alps $\left(1: 1^{\prime} 000^{\prime} 000\right)$. Paris: Commission for the Geological Map of the World (UNESCO).

O'Driscoll, L. J., HuMPhreys, E. D. \& SAUCIER, F. 2009. Subduction adjacent to deep continental roots: Enhanced negative pressure in the mantle wedge, mountain building and continental motion. Earth and Planetary Science Letters 280, 61-70.

Oveisi, B., LaVe, J., VAN DER BeEK, P., CARCAillet, J., BenedetTI, L. \& Aubourg, C. 2009. Thick- and thinskinned deformation rates in the central Zagros simple folded zone (Iran) indicated by displacement of geomorphic surfaces. Geophysical Journal International 176, 627-54.

PaCe, P. \& CAlamita, F. 2014. Push-up inversion structures v. fault-bend reactivation anticlines along oblique thrust ramps: examples from the Apennines fold-and-thrust belt (Italy). Journal of the Geological Society, London 171, 227-38.

Pace, P., Scisciani, V., Calamita, F., Butler, R. W. H., IACOPINI, D., ESESTIME, P. \& HodGSON, N. 2015. Inversion structures in a foreland domain: seismic examples from the Italian Adriatic Sea. Interpretation 3, 161-76.

Parra, M., Mora, A., Jaramillo, C., Strecker, M. R., Sobel, E. R., Quiroz, L., RuedA, M. \& Torres, V. 2009a. Orogenic wedge advance in the northern Andes: evidence from the Oligocene-Miocene sedimentary record of the Medina Basin, Eastern Cordillera, Colombia. Geological Society of America Bulletin 121, 780-800.

Parra, M., Mora, A., Sobel, E. R., Strecker, M. R. \& GONZALEZ, R. 2009b. Episodic orogenic front migration in the northern Andes: constraints from low-temperature thermochronology in the Eastern Cordillera. Tectonics 28, TC4004, doi: 10.1029/2008TC002423.

PAUL, D. \& MiTRA, S. 2012. Controls of basement faults on the geometry and evolution of compressional basementinvolved structures. American Association of Petroleum Geologists Bulletin 96, 1899-930.

Perarnau, M., Gilbert, H., Alvarado, P., Martino, R. \& ANDERSON, M. 2012. Crustal structure of the Eastern
Sierras Pampeanas of Argentina using high frequency local receiver functions. Tectonophysics 580, 208-17.

PFIFFNER, O. A. 2006. Thick-skinned and thin-skinned styles of continental contraction. In Styles of Continental Contraction (eds S. Mazzoli \& R. W. H. Butler), pp. 153-77. Geological Society of America Special Papers no. 414.

PFIFFNER, O. A. 2016. Basement-involved thin-skinned and thick-skinned tectonics in the Alps. In Tectonic Evolution and Mechanics of Basement-Involved Fold-andThrust Belts (eds O. Lacombe, J. Ruh, D. Brown \& F. Nilfouroushan). Geological Magazine.

Pfiffner, O. A., ElLIS, S. \& BEAUMONT, C. 2000. Collision tectonics in the Swiss Alps: insights from geodynamic modeling. Tectonics 19, 1065-94.

Pfiffner, O. A., Erard, P. F. \& Stauble, M. 1997. Two cross sections through the Swiss Molasse Basin. In Deep Structure of the Swiss Alps: Results of NRP 20 (eds O. A. Pfiffner, P. Lehner, P. Heitzmann, St. Mueller \& A. Steck), pp. 64-71. Basel: Birkhäuser Verlag.

Philippe, Y., Colletta, B., Deville, E. \& Mascle, A. 1996. The Jura fold-and-thrust belt: a kinematic model based on map-balancing. In Peri-Tethys Memoir 2 Structure and Prospects of Alpine Basins and Forelands (eds P. Ziegler \& F. Horvath), pp. 235-61. Mémoires du Museum National d'Histoire Naturelle, Paris, no. 170.

PhilipPe, Y., DeVILle, E. \& MASClE, A. 1998. Thin-skinned inversion tectonics at oblique basin margins: example of the western Vercors and Chartreuse Subalpine massifs (SE France). In Cenozoic Foreland Basins of Western Europe (eds A. Mascle, C. Puigdefabregas, H. P. Luterbacher \& M. Fernandez), pp. 239-62. Geological Society of London, Special Publication no. 134.

PILGER, R. H. 1981. Plate reconstruction, aseismic ridges, and low-angle subduction beneath the Andes. Geological Society of America Bulletin 92, 448-56.

PoBlET, J. \& LisLe, R. J. 2011. Kinematic evolution and structural styles of fold-and-thrust belts. In Kinematic Evolution and Structural Styles of Fold-and-Thrust Belts (eds J. Poblet \& R. J. Lisle), pp. 1-24. Geological Society of London, Special Publication no. 349.

Ramos, V. A., Cristallini, E. \& Perez, D. J. 2002. The Pampean flat-slab of the Central Andes. Journal of South America Earth Sciences 15, 59-78.

Ramos, V. A., ZAPATA, T., Cristallini, E. \& Introcaso, A. 2004. The Andean thrust system - latitudinal variations in structural styles and orogenic shortening. In Thrust Tectonics and Hydrocarbon Systems (ed. K. R. McClay), pp. 30-50. American Association of Petroleum Geologists Memoir no. 82.

RAU, R.-J., LEE, J.-C., CHING, K.-E., LEe, Y.-H., BYRNE, T. B. \& CHEN, R.-Y. 2012. Subduction-continent collision in southwestern Taiwan and the 2010 Jiashian earthquake sequence. Tectonophysics 578, 107-16.

Régnier, M., Chatelain, J., Smalley, R., Chiu, J. M., IsACKS, B. \& PUEBLA, N. 1992. Seismotectonics of the Sierra Pie de Palo, a basement block uplift in the Andean foreland, Argentina. Bulletin of the Seismological Society of America 82, 2549-71.

REILINGER, R. \& KADINSKY-CADE, K. 1985. Earthquake deformation cycle in the Andean back arc, western Argentina. Journal of Geophysical Research 90, 12701-12.

RESTON, T. \& MANATSCHAL, G. 2011. Rifted margins: building blocks of later collision. In Arc-Continent Collision: Frontiers in Earth Sciences (eds D. Brown \& P. D. Ryan), pp. 3-21. Berlin: Springer-Verlag.

RodGERS, J. 1949. Evolution of thought on structure of middle and southern Appalachians. American Association of Petroleum Geologists Bulletin 33, 1643-54. 
RODRIGUEZ-ROA, F. A. \& WILTSCHKO, D. V. 2010. Thrust belt architecture of the central and southern Western Foothills of Taiwan. In Hydrocarbons in Contractional Belts (eds G. P. Goffey, J. Craig, T. Needham \& R. Scott), pp. 137-68. Geological Society of London, Special Publication no. 348 .

Rolland, Y., CoX, S., Boullier, A. M., Pennacchioni, G. \& MANCKTELOW, N. 2003. Rare earth and trace element mobility in mid-crustal shear zones: Insights from the Mont Blanc Massif(Western Alps). Earth and Planetary Science Letters 214, 203-19.

Rolland, Y., CoX, S. F. \& CoRsinI, M. 2009. Constraining deformation stages in brittle-ductile shear zones from combined field mapping and Ar-40/Ar-39 dating: the structural evolution of the Grimsel Pass area (Aar Massif, Swiss Alps). Journal of Structural Geology 31, 1377-94.

Rolland, Y., Rossi, M., Cox, S. F., Corsini, M., Mancktelow, N., Pennacchioni, G., Fornari, M. \& Boullier, A. M. 2008. ${ }^{40} \mathrm{Ar} /{ }^{39} \mathrm{Ar}$ dating of synkinematic white mica: insights from fluid-rock reaction in low-grade shear zones (Mont Blanc Massif) and constraints on timing of deformation in the NW external Alps. In The Internal Structure of Fault Zones: Implications for Mechanical and Fluid-Flow Properties (eds C. A. J. Wibberley, W. Kurz, J. Imber, R. E. Holdsworth \& C. Collettini), pp. 293-315. Geological Society of London, Special Publication no. 299.

ROTSTEIN, Y. \& SCHAMING, M. 2004. Seismic reflection evidence for thick-skinned tectonics in the northern Jura. Terra Nova 16, 250-6.

ROURE, F. 2008. Foreland and hinterland basins: what controls their evolution? Swiss Journal of Geoscience 101, $5-29$.

Roure, F., Choukroune, P., Berastegui, X., Munoz, J. A., Villien, A., Matheron, P., BAREyt, M., Seguret, M., CAmarA, P. \& Deramond, J. 1989. Ecors deep seismic data and balanced cross sections: geometric constraints on the evolution of the Pyrenees. Tectonics 8, 41-50.

Roure, F. \& CollettA, B. 1996. Cenozoic inversion structures in the foreland of the Pyrenees and Alps. In Structure and Prospects of Alpine Basins and Forelands, Peri-Tethys Memoir 2 (eds P. A. Ziegler \& F. Horvath), pp. 173-209. Memoirés du Museum National d'Histoire Naturelle, Paris, no. 170.

Roure, F., Howell, D. G., Guellec, S. \& Casero, P. 1990. Shallow structures induced by deep-seated thrusting. In Petroleum and Tectonics in Mobile Belts (ed. J. Letouzey), pp. 15-30. Paris: Editions Technip.

RuBATto, D. \& HERMANN, J. 2001. Exhumation as fast as subduction? Geology 29, 3-6.

SAleEbY, J. B. 2003. Segmentation of the Laramide slab evidence from the southern Sierra Nevada region. Geological Society of America Bulletin 115, 655-68.

SANCHEZ, G., Rolland, Y., Schneider, J., Corsini, M., Oliot, E., Goncalves, P., Verati, C., LardeauX, J. M. \& MARQUER, D. 2011. Dating low-temperature deformation by ${ }^{40} \mathrm{Ar} /{ }^{39} \mathrm{Ar}$ on white mica, insights from the Argentera-Mercantour Massif (SW Alps). Lithos 125, 521-36.

SANDIFORD, M. 1999. Mechanics of basin inversion. Tectonophysics 305, 109-20.

Sassi, W., Colletta, B., Bale, P. \& Paquereau, T. 1993. Modelling of structural complexity in sedimentary basins: the role of pre-existing faults in thrust tectonics. Tectonophysics 226, 97-112.

Satolli, S., Pace, P., Viandante, M. G. \& Calamita, F. 2014. Lateral variations in tectonic style across cross- strike discontinuities: an example from the Central Apennines belt (Italy). International Journal of Earth Sciences 103, 2301-13.

SAURA, E. \& TEIXELL, A. 2006. Inversion of small basins: effects on structural variations at the leading edge of the Axial Zone antiformal stack (Southern Pyrenees, Spain). Journal of Structural Geology 28, 1909-20.

Schmidt, C. J., Genovese, P. W. \& Chase, R. B. 1993. Role of basement fabric and cover-rock lithology on the geometry and kinematics of twelve folds in the Rocky Mountain foreland. In Laramide Basement Deformation in the Rocky Mountain Foreland of the Western United States (eds C. J. Schmidt, R. B. Chase \& E. A. Erslev), pp. 1-44. Geological Society of America Special Papers no. 280.

SCISCIANI, V. 2009. Styles of positive inversion tectonics in the Central Apennines and in the Adriatic foreland: Implications for the evolution of the Apennine chain (Italy). Journal of Structural Geology 31, 1276-94.

Scisciani, V., Agostini, S., Calamita, F., Cilli, A., Giori, I., PACE, P. \& PALTRINIERI, W. 2010. The influence of preexisting extensional structures on the Neogene evolution of the Northern Apennines foreland fold-and-thrust belt. Rendiconti Online Società Geologica Italiana 10, 1258.

Scisciani, V., Agostini, S., Calamita, F., Pace, P., Cilli, A., GIORI, I. \& PALTRINIERI, W. 2014. Positive inversion tectonics in foreland fold-and-thrust belts: a reappraisal of the Umbria-Marche Northern Apennines (Central Italy) by integrating geological and geophysical data. Tectonophysics 637, 218-37.

SCisciani, V. \& Montefalcone, R. 2006. Coexistence of thin-and thick-skinned tectonics: an example from the Central Apennines, Italy. In Styles of Continental Contraction (eds S. Mazzoli \& W. H. Butler), pp. 33-54. Geological Society of America Special Papers no. 414.

SeAger, W. R., Mack, G. H. \& LAwTON, T. F. 1997. Structural kinematics and depositional history of a Laramide uplift-basin pair in southern New Mexico: implications for development of intraforeland basins. Geological Society of America Bulletin 109, 1389-401.

SePeHr, M. \& Cosgrove, J. W. 2005. Role of the Kazerun Fault Zone in the formation and deformation of the Zagros fold-thrust belt, Iran. Tectonics 24, TC5005, doi: 10.1029/2004TC001725.

Shen, H.-C., HuAnG, S.-T., TANG, C.-H. \& Hsu, Y.-Y. 1996. Geometrical characteristics of structural inversion on the offshore of Miaoli, Taiwan. Petroleum Geology of Taiwan 30, 79-110.

SHERIFF, R. E. 2002. Encyclopedic Dictionary of Applied Geophysics. Society of Exploration Geophysicists, 442 pp.

SHERKATI, S. \& LETOUZEY, J. 2004. Variation of structural style and basin evolution in the central Zagros (Izeh zone and Dezful Embayment), Iran. Marine and Petroleum Geology 21, 535-54.

SHERKATI, S., LETOUZEY, J. \& FRIZON DE LAMOTTE, D. 2006. Central Zagros fold-thrust belt (Iran): new insights from seismic data, field observation, and sandbox modeling. Tectonics 25, TC4007, doi: 10.1029/2004TC001766.

SiAme, L. L., BEllier, O. \& SÉBrier, M. 2006. Active tectonics in the Argentine Precordillera and Western Sierras Pampeanas. Revista de la Asociación Geológica Argentina 61, 604-19.

SiAme, L. L., Bellier, O., SÉBrier, M., Bourlès, D. L., Leturmy, P., Perez, M. \& Araujo, M. 2002. Seismic hazard reappraisal from combined structural geology, geomorphology and cosmic ray exposure dating 
analyses: the Eastern Precordillera thrust system (NW Argentina). Geophysical Journal International 150, 241-60.

Siame, L. L., Sebrier, M., Bellier, O., Bourlès, D., Costa, C., Ahumada, E. A., Gardini, C. E. \& Cisneros, H. 2015. Active basement uplift of Sierra Pie de Palo (Northwestern Argentina): rates and inception from ${ }^{10} \mathrm{Be}$ cosmogenic nuclide concentrations. Tectonics 34, 1129-53.

SiBSON, R. H. 1995. Selective fault reactivation during basin inversion: potential for fluid redistribution through faultvalve action. In Basin Inversion (eds J. G. Buchanan \& P. G. Buchanan), pp. 3-19. Geological Society of London, Special Publication no. 88.

Simon-Labric, T., Rolland, Y., DumOnt, T., Heymes, T., Authemayou, C., Corsini, M. \& Fornari, M. 2009. Ar-40/Ar-39 dating of Penninic Front tectonic displacement (W Alps) during the Lower Oligocene (31-34 Ma). Terra Nova 21, 127-36.

Sinclair, H. D., Gibson, M., NAYlor, M. \& Morris, R. G. 2005. Asymmetric growth of the Pyrenees revealed through measurement and modeling of orogenic fluxes. American Journal of Science 305, 369-406.

SMALLEY, R. F. \& IsACKS, B. L. 1987. A high resolution local network study of the Nazca Plate Wadati-Benioff zone under western Argentina. Journal of Geophysical Research 92, 13903-13.

Smalley, JR., R. \& IsACKS, B. L. 1990. Seismotectonics of thin- and thick-skinned deformation in the Andean foreland from local network data; evidence for a seismogenic lower crust. Journal of Geophysical Research 95, 12487-98.

Smalley, R. J., Pujol, J., Regnier, M., Chiu, J.-M., Chatelain, J. L., Isacks, B. L., Araujo, M. \& Puebla, N. 1993. Basement seismicity beneath the Andean Precordillera thin-skinned thrust belt and implications for crustal and lithospheric behavior. Tectonics 12, 63-76.

Smithson, S. B., Brewer, J. A., Kaufman, S., Oliver, J. E. \& HuRICH, C. A. 1979. Structure of the Laramide Wind River uplift, Wyoming, from COCORP deep reflection data and from gravity data. Journal of Geophysical Research 84, 5955-72.

Sobel, E. R. \& Dumitru, T. A. 1997. Thrusting and exhumation around the margins of the western Tarim basin during the India-Asia collision. Journal of Geophysical Research 102, 5043-63.

Sobel, E. R., Hilley, G. E. \& Strecker, M. R. 2003. Formation of internally drained contractional basins by aridity-limited bedrock incision. Journal of Geophysical Research 108, 2344.

Sobel, E. R. \& STRECKER, M. R. 2003. Uplift, exhumation and precipitation: tectonic and climatic control of Late Cenozoic landscape evolution in the northern Sierras Pampeanas, Argentina. Basin Research 15(4), 431-51.

SpanG, J. H. \& Evans, J. P. 1988. Geometrical and mechanical constraints on basement-involved thrusts in the Rocky Mountain foreland province. In Interaction of the Rocky Mountain Foreland and the Cordilleran Thrust Belt (eds C. J. Schmidt \& W. J. Perry), pp. 41-51. Geological Society of America Memoir no. 171.

SperanZA, F. \& ChIAPPINI, M. 2002. Thick-skinned tectonics in the external Apennines, Italy: new evidence from magnetic anomaly analysis. Journal of Geophysical Research 107, 2290, doi: 10.1029/2000JB000027.

STERN, R. J. 1985. The Najd fault system, Saudi Arabia and Egypt: a late Precambrian rift-related transform system? Tectonics 4, 497-511.
Stewart, M., Holdsworth, R. E. \& Strachan, R. A. 2000. Deformation processes and weakening mechanisms within the frictional-viscous transition zone of major crustal-scale faults: insights from the Great Glen Fault Zone, Scotland. Journal of Structural Geology 22, 543-60.

STOCKLIN, J. 1968. Structural history and tectonics of Iran; a review. American Association of Petroleum Geologists Bulletin 52, 1229-58.

Stockmal, G. S., Beaumont, C., NGuyen, M. \& Lee, B. 2007. Mechanics of thin skinned fold-and-thrust belts: insights from numerical models. In Whence the Mountains? Inquiries into the Evolution of Orogenic Systems: A Volume in Honor of Raymond A. Price (eds J. W. Sears, T. A. Harms \& C. A. Evenchick), pp. 63-98. Geological Society of America Special Papers no. 443.

STONE, D. S. 1993. Basement-involved thrust-generated folds as seismically imaged in the sub-surface of the central Rocky Mountain foreland. In Laramide Basement Deformation in the Rocky Mountain Foreland of the Western United States (eds C. J. Schmidt, R. B. Chase \& E. A. Erslev), pp. 271-312. Geological Society of America Special Papers no. 280.

Stone, D. S. 2002. Morphology of the Casper Mountain uplift and related subsidiary structures, central Wyoming; implications for Laramide kinematics, dynamics, and crustal inheritance. American Association of Petroleum Geologists Bulletin 86, 1417-40.

Strecker, M. R., Cerveny, P., Bloom, A. L. \& Malizia, D. 1989. Late Cenozoic tectonism and landscape development in the foreland of the Andes: Northern Sierras Pampeanas $\left(26^{\circ}-28^{\circ} \mathrm{S}\right)$, Argentina. Tectonics 8, 51734.

Strecker, M. R., Hilley, G. E., Bookhagen, B. \& SOBEL, E. R. 2012. Structural, geomorphic, and depositional characteristics of contiguous and broken foreland basins: examples from the eastern flanks of the central Andes in Bolivia and NW Argentina. In Tectonics of Sedimentary Basins: Recent Advances (eds C. Busby \& A. Azor), pp. 508-21. Chichester: John Wiley \& Sons.

Stuart, C. J., NemcoK, M., Vangelov, D., Higgins, E. R., Welker, C. \& MeauX, D. 2011. Structural and depositional evolution of the Eastern Balkan thrust belt, Bulgaria. Association of Petroleum Geologists Bulletin 95, 649-73.

SuPPE, J. 1976. Décollement folding in southwestern Taiwan. Petroleum Geology of Taiwan 13, 25-35.

SUPPE, J. 1980. Imbricated structure of western foothills belt, south central Taiwan. Petroleum Geology of Taiwan 17, $1-16$.

SuPPE, J. \& NAMSON, J. 1979. Fault-bend origin of frontal folds of the western Taiwan fold-and-thrust belt. Petroleum Geology of Taiwan 16, 1-18.

TALBOT, C. J. \& ALAVI, M. 1996. The past of a future syntaxis across the Zagros. In Salt Tectonics (eds G. I. Alsop, D. J. Blundell \& I. Davison), pp. 89-109. Geological Society of London, Special Publication no. 100.

TALEBIAN, M. \& JACKSON, J. A. 2004. A reappraisal of earthquake focal mechanisms and active shortening in the Zagros mountains of Iran. Geophysical Journal International 156, 506-26.

Tapponnier, P., Meyer, B., Avouac, J. P., Peltzer, G., Gaudemer, Y., GuO, S. M., XiAng, H. F., Yin, K. L., Chen, Z. T., CAI, S. H. \& DAI, H. G. 1990. Active thrusting and folding in the Qilian-Shan, and decoupling between upper crust and mantle in the northeastern Tibet. Earth and Planetary Science Letters 97, 382-403. 
TAVARNELLI, E. 1997. Structural evolution of a foreland foldand-thrust belt: the Umbria-Marche Apennines, Italy. Journal of Structural Geology 19, 523-34.

Tavarnelli, E., Butler, R. W. H., Decandia, F. A., Calamita, F., Grasso, M., Alvarez, W. \& Renda, P. 2004. Implications of fault reactivation and structural inheritance in the Cenozoic tectonic evolution of Italy. In The Geology of Italy, Special Volume 1 (eds U. Crescenti, S. D’Offizi, S. Merlini \& R. Sacchi), pp. 209-22. Società Geologica Italiana.

TeIXELL, A. 1996. The Anso transect of the southern Pyrenees: basement and cover thrust geometries. Journal of the Geological Society, London 153, 301-10.

TeiXell, A., Arboleya, M. L., Julivert, M. \& Charroud, M. 2003. Tectonic shortening and topography in the central High Atlas (Morocco). Tectonics 22, 1051, doi: 10.1029/2002TC001460.

TEng, L. S. 1990. Geotectonic evolution of late Cenozoic arc-continent collision in Taiwan. Tectonophysics 183, $57-76$.

TIKOFF, B. \& MAXsON, J. 2001. Lithospheric buckling of the Laramide foreland during Late Cretaceous and Paleogene, western United States. Rocky Mountain Geology 36, 13-35.

Tozer, R. S. J., Butler, R. W. H., Corrado, S., Geologiche, S., Tre, R., San, L. \& Murialdo, L. 2002. Comparing thin- and thick-skinned thrust tectonic models of the Central Apennines, Italy. EGU Stephan Mueller Special Publication Series 1, 181-94.

TRICART, P. \& LEMOINE, M. 1986. From faulted blocks to megamullions and megaboudins - Tethyan heritage in the structure of the Western Alps. Tectonics 5, 95-118.

TrufFert, C., Burg, J.-P, CAZES, M., Byer, R., DAmotte, B. \& REY, D. 1990. Structures crustales sous le Jura et la Bresse; constraintes sismiques et gravimétriques le long des profils Ecors Bresse-Jura et Alpes. In Deep Structure of the Alps (eds F. Roure, P. Heitzmann \& R. Polino), pp 157-64. Société Géologique de France, Memoir no. 156.

TURner, J. P. \& Williams, G. 2004. Sedimentary basin inversion and intraplate shortening. Earth-Science Reviews 65, 277-304.

Turrini, C., Angeloni, P., Lacombe, O., Ponton, M. \& ROURE, F. 2015. Three-dimensional seismo-tectonics in the Po Valley basin, Northern Italy. Tectonophysics $\mathbf{6 6 1}$, 156-79.

USTASZEWSKI, K. \& SCHMID, S. M. 2006. Control of preexisting faults on geometry and kinematics in the northernmost part of the Jura fold-and-thrust belt. Tectonics 25, TC5003, doi: 10.1029/2005TC001915.

Ustaszewski, K. \& ScHMID, S. M. 2007. Latest Pliocene to recent thick-skinned tectonics at the Upper Rhine Graben - Jura Mountains junction. Swiss Journal of Geosciences 100, 293-312.

Vacherat, A., Mouthereau, F, Pik, R., Bernet, M., Gautheron, C., Masini, E., Le Pourhiet, L., Tibaric, B. \& LAHFID, A. 2014. Thermal imprint of rift-related processes in orogens as recorded in the Pyrenees. Earth and Planetary Science Letters 408, 296-306.

VAN DeR BeeK, P. A., VAlla, P. G., Herman, F., Braun, J., Persano, C., Dobson, K. J. \& Labrin, E. 2010. Inversion of thermochronological age elevation profiles to extract independent estimates of denudation and relief history-II: application to the French Western Alps. Earth and Planetary Science Letters 296, 9-22.

van Hunen, J., VAN DEN BERG, A. \& VlarR, N. J. 2002. On the role of subducting oceanic plateaus in the devel- opment of shallow flat subduction. Tectonophysics $\mathbf{3 5 2}$, 317-33.

Verges, J., Fernandez, M. \& Martinez, A. 2002. The Pyrenean orogen: pre-, syn-, and postcollisional evolution. Journal of the Virtual Explorer 8, 55-74.

Verges, J., Ramos, V. A., Meigs, A., Cristallini, E., BETTINI, F. H. \& CORTES, J. M. 2007. Crustal wedging triggering recent deformation in the Andean thrust front between $31^{\circ} \mathrm{S}$ and $33^{\circ} \mathrm{S}$ : Sierras PampeanasPrecordillera interaction. Journal of Geophysical Research 112, B03S15, doi: 10.1029/2006JB004287.

VERNON, A. J., VAN DER BEEK, P. A., SINClAIR, H. D. \& RAHN, M. K. 2008. Increase in late Neogene denudation of the European Alps confirmed by analysis of a fissiontrack thermochronology database. Earth and Planetary Science Letters 270, 316-29.

Watts, A. B., Lamb, S. H., Fairhead, J. D. \& Dewey, J. F. 1995. Lithospheric flexure and bending of the central Andes. Earth and Planetary Science Letters 134, 9-21.

WAYNE, D. M. \& MCCAIG, A. M., 1998. Dating fluid flow in shear zones: $\mathrm{Rb}-\mathrm{Sr}$ and $\mathrm{U}-\mathrm{Pb}$ studies of syntectonic veins in the Néouvielle Massif, Pyrenees. In Dating and Duration of Fluid Flow and Fluid-Rock Interaction (ed. J. Parnell), pp. 129-35. Geological Society of London, Special Publication no. 144.

Wen, S., Hsu, H.-J., Chang, W.-Y. \& Chen, C.-H. 2012. A study of the seismogenic process beneath the southwestern foothills in Taiwan in relation with the 2010 Jiasian earthquake. Tectonophysics 578, 107-16.

WIBBERLEY, C. 2005. Initiation of basement thrust detachments by fault-zone reaction weakening. In High Strain Zones: Structures and Physical Properties (eds D. Bruhn \& L. Burlini), pp. 347-72. Geological Society of London, Special Publication no. 245.

Williams, C. A., ConNors, C., Dahlen, F. A., Price, E. J. \& SUPPE, J. 1994. Effect of the brittle-ductile transition on the topography of compressive mountain belts on Earth and Venus. Journal of Geophysical Research 99, 19947-74.

WiLlingShOFER, E. \& SoKOUTIS, D. 2009. Decoupling along plate boundaries: key variable controlling the mode of deformation and the geometry of collisional mountain belts. Geology 37, 39-42.

WiLLingShOFER, E., SOKOUTIS, D., LUTH, S. W., BEEKMAN, F. \& Cloetingh, S. 2013. Subduction and deformation of the continental lithosphere in response to plate and crust-mantle coupling. Geology 41, 1239-42.

WinsLOW, M. A. 1981. Mechanisms for basement shortening in the Andean foreland fold belt of southern South America. In Thrust and Nappe Tectonics (eds K. McClay \& J. N. Price), pp. 513-28. Geological Society of London, Special Publication no 9.

Worthington, L. L., Miller, K. C., Erslev, E. A., ANDERSON, M. L., CHAMBERlain, K. R., SHEEHAN, A. F., YeCK, W. L., HARDER, S. H. \& SidDOWAY, C. S. 2016. Crustal Structure of the Bighorn Mountains Region: Precambrian Influence on Laramide Shortening and Uplift in North-Central Wyoming. Tectonics, published online 30 January 2016. doi: 10.1002/2015TC003840.

WU, F. T., ChanG, C. S. \& WU, Y.-M. 2004. Precisely relocated hypocenters, focal mechanisms and active orogeny in Central Taiwan. In Aspects of the Tectonic Evolution of China (eds J. Malpas, C. J. N. Fletcher, J. R. Ali \& J. C. Aitchison), pp. 333-54. Geological Society of London, Special Publication no. 226.

Wu, Y.-M., CHANG, C.-H., ZHAO, L., TENG, L. T. \& NAKAMURA, M. 2008. A comprehensive relocation of 
earthquakes in Taiwan from 1991 to 2005. Bulletin of the Seismological Society of America 98, 1471-81.

Wu, F., RAU, R.-J. \& SAlZBERG, D. 1997. Taiwan Orogeny; thin-skinned or lithospheric collision? An introduction to active tectonics in Taiwan. Tectonophysics 274, 191220.

YAmato, P., Kaus, B. J. P., Mouthereau, F. \& CAStelltort, S. 2011. Dynamic constraints on the crustal-scale rheology of the Zagros fold belt, Iran. Geology 39, 815-8.

YanG, K.-M., Huang, S.-T., Wu, J.-C., LeE, M., TinG, H.H. \& MEI, W.-W. 2001. The characteristics of subsurface structure and evolution of the TachienshanChukou thrust system. Annual Meeting of the Geological Society of China 2001, pp. 82-4.

YAnG, K.-M., HuAnG, S.-T., Wu, J.-C., Ting, H. H. \& MEI, W.-W. 2006. Review and new insights on foreland tectonics in Western Taiwan. International Geology Review 48, 910-41.

YANG, K.-M., Ting, H.-H., WU, J. C. \& CHI, W.-R. 1997. Geological model for complex structures and its implications for hydrocarbon exploration in northwestern Taiwan. Petroleum Geology of Taiwan 31, 1-42.

YANG, K.-M., WU, J.-C., TING, H.-H., WANG, J.-B. \& CHI, W.-R. 1994. Sequential deformation in foothills belt, Hsinchu and Miaoli areas: implications in hydrocarbon accumulation. Petroleum Geology of Taiwan 29, 47-74.

YANG, K.-M., Wu, J.-C., Wickham, J.-S., Ting, H.-H., WANG, J.-B. \& CHI, W.-R. 1996. Transverse structures in Hsinchu and Miaoli areas: structural mode and evol- ution in foothills belt, northwestern Taiwan. Petroleum Geology of Taiwan 30, 111-50.

Yeck, W. L., Sheehan, A. F., Anderson, M. L., Erslev, E. A., Miller, K. C. \& SiddowAY, C. S. 2014. Structure of the Bighorn Mountain region, Wyoming, from teleseismic receiver function analysis: implications for kinematics of Laramide shortening. Journal of Geophysical Research 119, 7028-7042.

YonKeE, A \& WeIL, A. B. 2015. Tectonic evolution of the Sevier and Laramide belts within the North American Cordillera orogenic system. Earth Science Reviews 150, 531-93.

YUE, L. F., SuPPE, J. \& HUNG, J.-H. 2005. Structural geology of a classic thrust belt earthquake: the 00201999 Chi-Chi earthquake Taiwan $(\mathrm{Mw}=7.6)$. Journal of Structural Geology 27, 2058-83.

ZAMBRANO, J. J. \& SuVIRES, G. M. 2008. Actualización en el límite entre sierras Pampeanas occidentales y Precordillera Oriental, en la provincia de San Juan. Revista de la Asociación Geológica Argentina 63, 110-16.

ZIEGLER, P. A. 1989. Geodynamic model for Alpine intraplate compressional deformation in Western and Central Europe. In Inversion Tectonics Meeting (eds M. A. Cooper \& G. D. Williams), pp. 63-85. Geological Society of London, Special Publication no. 44.

Ziegler, P. A., Bertotti, G. \& Cloetingh, S. 2002. Dynamic processes controlling foreland development - the role of mechanical (de)coupling of orogenic wedges and forelands. EGU Stephan Mueller Special Publication Series 1, 17-56. 